\title{
Preliminary Decommissioning Study Reports
}

\section{Volume 3: Low-Level Liquid Waste (LLW) Collection and Storage Tanks}

\author{
J. R. Horton
}

September 1984

Oak Ridge National Laboratory

Oak Ridge, Tennessee 37830

operated by

Martin Marietta Energy Systems, Inc.

ior the

DEPARTMENT OF ENERGY 
This report has ber I reproduced directly from the best available copy.

Available to DOE and DOE contractors from the Otfice of Scientific and Technical information, P.O. Box 62, Oak Ridge, TN 37831; prices avallable from (615) 576-8401, FTS 626-8401.

Available to the public from the National Technical Information Service, U.S. Department of Commerce, 5285 Port Royal Rd., Springtield, VA 22161.

NTIS price codes-Printed Copy: A 10 Microtiche AO1

This report was prepared as an account of work sponsored by an agency of the United States Government. Netther the United States Government nor any agency thereof, nor any of their employees, makes any warranty, express or implied, or assumes any legal liability or responsibility for the accuracy, completeness, or usefuiness of any information, apparatus, product, or process disclosed, or represents that its use would not infringe privately owned rights. Reference herein to any specific commercial product, process, or service by trade name, trademark, manutacturer, or otherwise, does not necessarily constitute or imply its endorsement, recommendation, or favoring by the United States Government or any agency thoreot. The views and opinions of authors expreseed herein do not necessarily state or reflect those of the United States Government or any agericy thereof. 


\section{Engineering Division}

\section{PRELIMINARY DECOMMISSIONING STUDY REPORTS \\ Volume 3: LOW-LEVEL LIQUID WASTE (T,LW) \\ COLLECTION AND STORAGE TANKS}

J. R. Horton

Approved by :

$$
\text { F.J.Peret 9-25-84 }
$$

F. J. Peretz, PrincipaI Engineer, Engineering Division

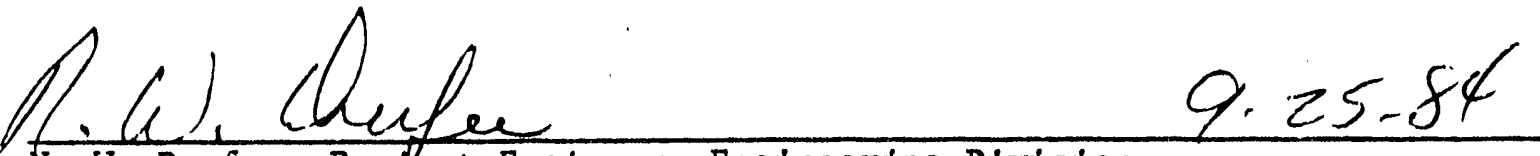

N. W. Durfee, Project Engineer, Engineering Division

$$
\text { J.S.M mih 9/25/84 }
$$

T. E. Myrick, okNL Surplus Facilities Management Program 


\section{Contents}

$\underline{\text { Page }}$

1.0 INTRODUCTIUN 1

2.0 HACILITY DESCRIPTION 2

2.1 Small Concrete Tanks $W-1$ and $W-2 \quad 2$

2.1.1 Location and Adjacent Facilities 2

2.1.2 Tank Construction 2

2.1.3 Tank History, Use, and Contents 9

2.1.4 Tank Access and Sampling 10

2.1.5 Kadiological Characterization 10

2.2 Intermediate S1ze Concrete Tanks $W-3$ and $W-4 \quad 16$

2.2.1 Location and Adjacent Facilities 16

2.2.2 Tank Construction 16

2.2.3 T'ank History and Contents 17

2.2.4 Tank Access and Sampling 18

2.2.5 Kadiological Characterization 18

2.3 Stainless Steel Tanks in North Tank Farm W-13, 18 $W-14$, and $W-15$

2.3.1 Location and Adjacent Facilities 18

2.3.2 Tank Construction 19

2.3.3 Tank History and Contents 19

2.3.4 Tank Access and Sampling 20

2.3.5 Radiological Uharacterization 20

2.4 Concrete Thorlum Waste Tank $\mathrm{TH}-4 \quad 20$

2.4.1 Location and Adjacent Facilities 20

2.4.2 Tank Construction 21

2.4.3 Tank History and Contents 21

2.4.4 Tank Access and Sampling 21

2.4.5 Radiological Characterization 21

2.5 Gunite Concrete Tank W-11 22

2.5.1 Location and Adjacent Facilities 22

2.5.2 Tank Construction 22

2.5.3 Tank History, Use, and Contents 22

2.5.4 Tank Access and Sampling 23

2.5.5 Kadiological Characterization 23

2.6 Stainless Steel Thorium Waste Tanks, TH-1, 23 $\mathrm{TH}-2$, and $\mathrm{TH}-3$

2.6.1 Location Adjacent Facilities 23

2.6.2 Tank Construction 23

2.6.3 T'ank History, Use, and Contents 24

2.6.4 Tank Access and Sampling 25

2.6.5 Radiological Characterization 25 
2.7 Isotope Area Stainless Steel Tank WC-1 26

2.7.1 Location and Adjacent Facilities 26

2.7.2 Tank Construction 26

2.7.3 Tank History, Use, and Contents 27

2.7.4 Tank Access and Sampling 27

2.7.5 Radiological Characterization 27

2.8 Building 4500 Area Stainless Steel Tanks WC-15 28 and WC- 17

2.8.1 Location and Adjacent Facilities 28

2.8.2 Tank Construction 28

2.8.3 Tank History, Use, and Contents 29

2.8.4 Tank Access and Sampling 29

2.8.5 Radiological Characterization 29

3.0 DECOMMISSIONING ALTERNATIVE ASSESSMENT 30

4.0 DESCRIPTION OF DECOMMISSIONING PLAN 32

$\begin{array}{lll}5.0 & \text { COST ESTIMATE AND SCHEDULE } & 36\end{array}$

$\begin{array}{lll}6.0 & \text { REFEKENCES } & 39\end{array}$

$\begin{array}{ll}\text { APPENDIX I } & 41\end{array}$ 


\subsection{INTRODUCTION}

Twenty-one low-level liquid radioactive waste collection and storage tanks are part of approximately 76 facllities currently managed by the ORNL Surplus Facilities Management Program (SFMP). This program, as part of the DOE national SFMP, is responsible for the maintenance and surveillance and the final decommissioning of radioactively contaminated surplus ORNL facilities. A long range planning effort is being conducted that will outline the scope and objectives of the ORNL program and establish decomissioning priorities based on health and safety concerns, budget constraints, and other programmatic constraints. In support of this SFMP planning activity, preliminary engineering assessments are being conducted for each of the ORNL surplus facllities currently managed under the program. These efforts are designed to: (1) provide an initial assessment of the potential decommissioning alternatives, (2) choose a preferred alternative and provide a fustification of the decommissioning plan, including cost and schedule estimates. D\&D of eight of the nine groups of surplus tanks are considered in this report. The ninth group (the large Gunite Storage Tanks) is covered in another report of this series, $\mathrm{X}-\mathrm{OE}-231, \mathrm{Vol} \cdot \mathbf{4}^{1}$ 


\subsection{FACILITY DESCRIPTION}

Since 1943, several tanks have been installed at ORNL for storage of liquid radioactive waste. Sixteen of twenty-one tanks involved in the ORNL SFMP are grouped in elght facilities for $D \& D$ consideration in this report. The eight groups covered in this report are Items $7,9,10,13,17,18$, and 19 as shown in Fig. 1 .

Two basic types of tanks, stainless steel and concrete (gunite), are Involved. Tanks of both types are subsurface and generally depend on the earthen cover and surroundings for shielding, although some of the steel tanks are embedded in concrete for additional shielding. A typical concrete tank is fllustrated in Fig. 2 and a typical steel tank in Fig. 3 . A listing of the vessels along with key parameters is provided in Table 1 for the concrete tanks and Table 2 for the steel tanks.

\subsection{Small Concrete Tanks $W-1$ and $W-2$}

\subsubsection{Location and Adjacent Facilities. The North Tank Farm is} located in the approximate center of the ORNL factlities at the X-10 site. This field contains both concrete and stainless steel tanks. Tanks $\mathrm{W}-1$ and W-2 were constructed in 1943 of reinforced Gunite spaced $18 \mathrm{ft}$ apart, center-to-center. Accessory equipment constructed originally with the tanks include two plug valve pits one standard valve pit, and a dry well for each tank.

\subsubsection{Tank Construction. Tanks $W-1$ and $W-2$ in the North Tank Farm} have an fnside diameter of $12 \mathrm{ft}$, a vertical sidewall helght of $8 \mathrm{ft}$ (with 


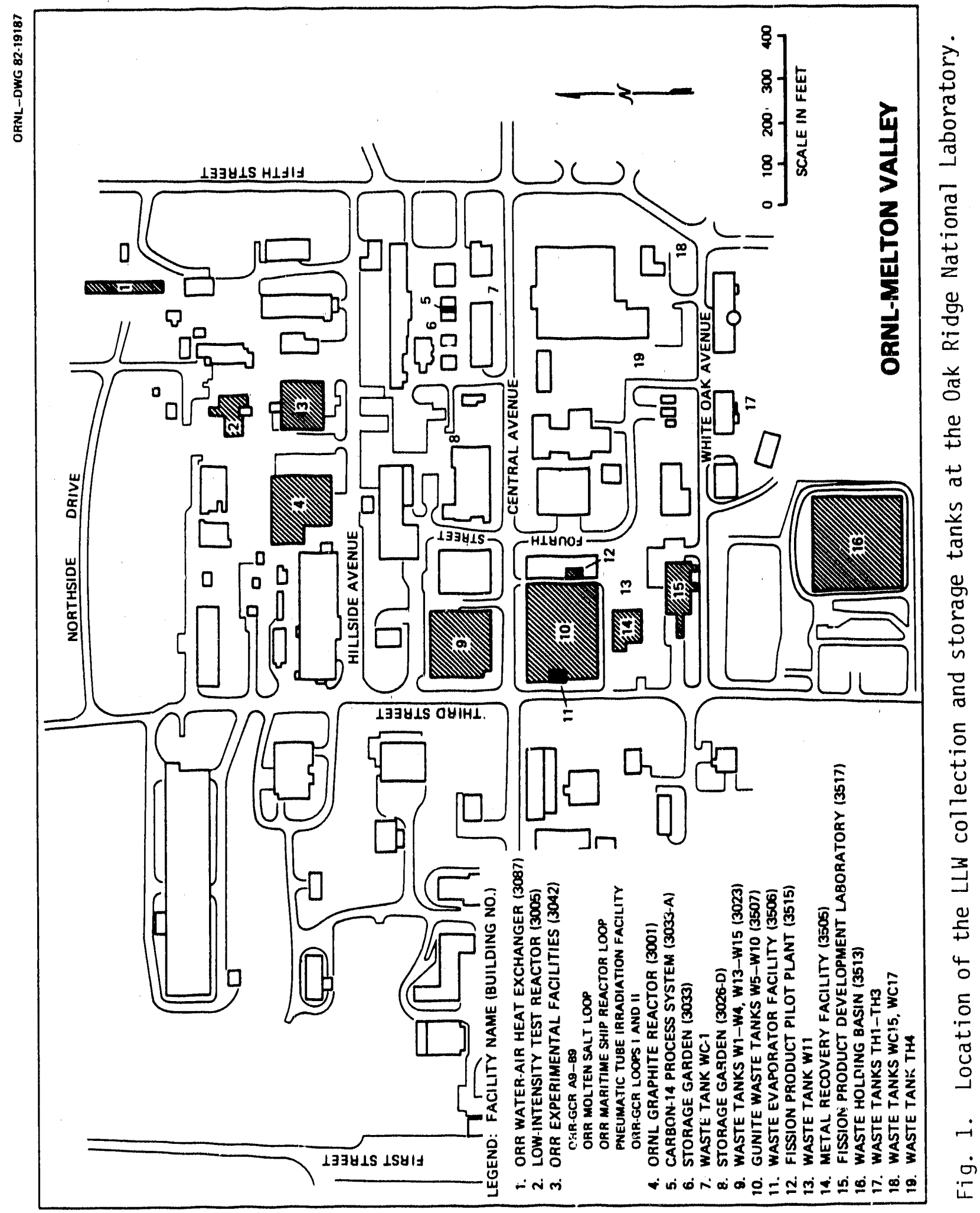




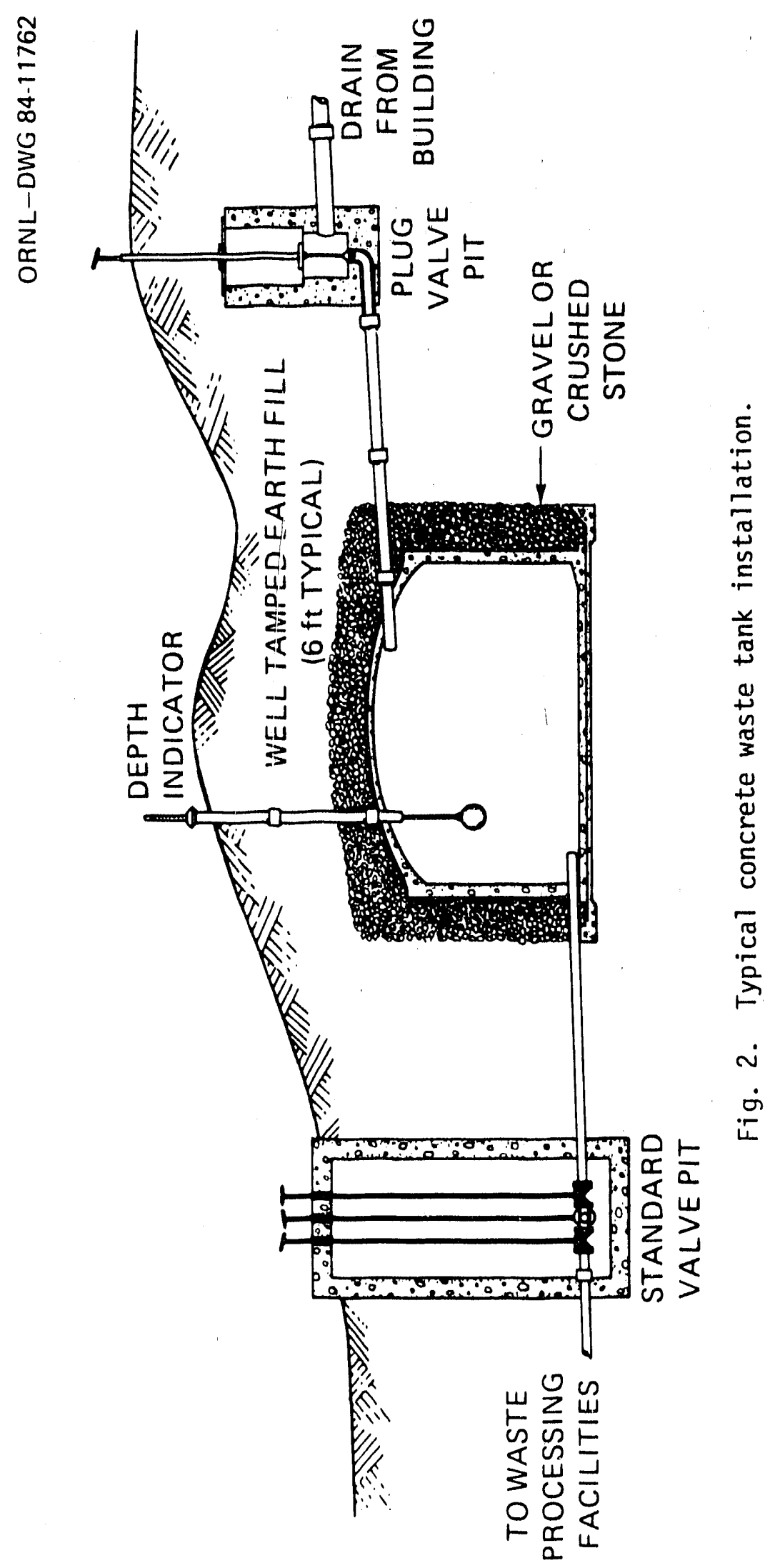




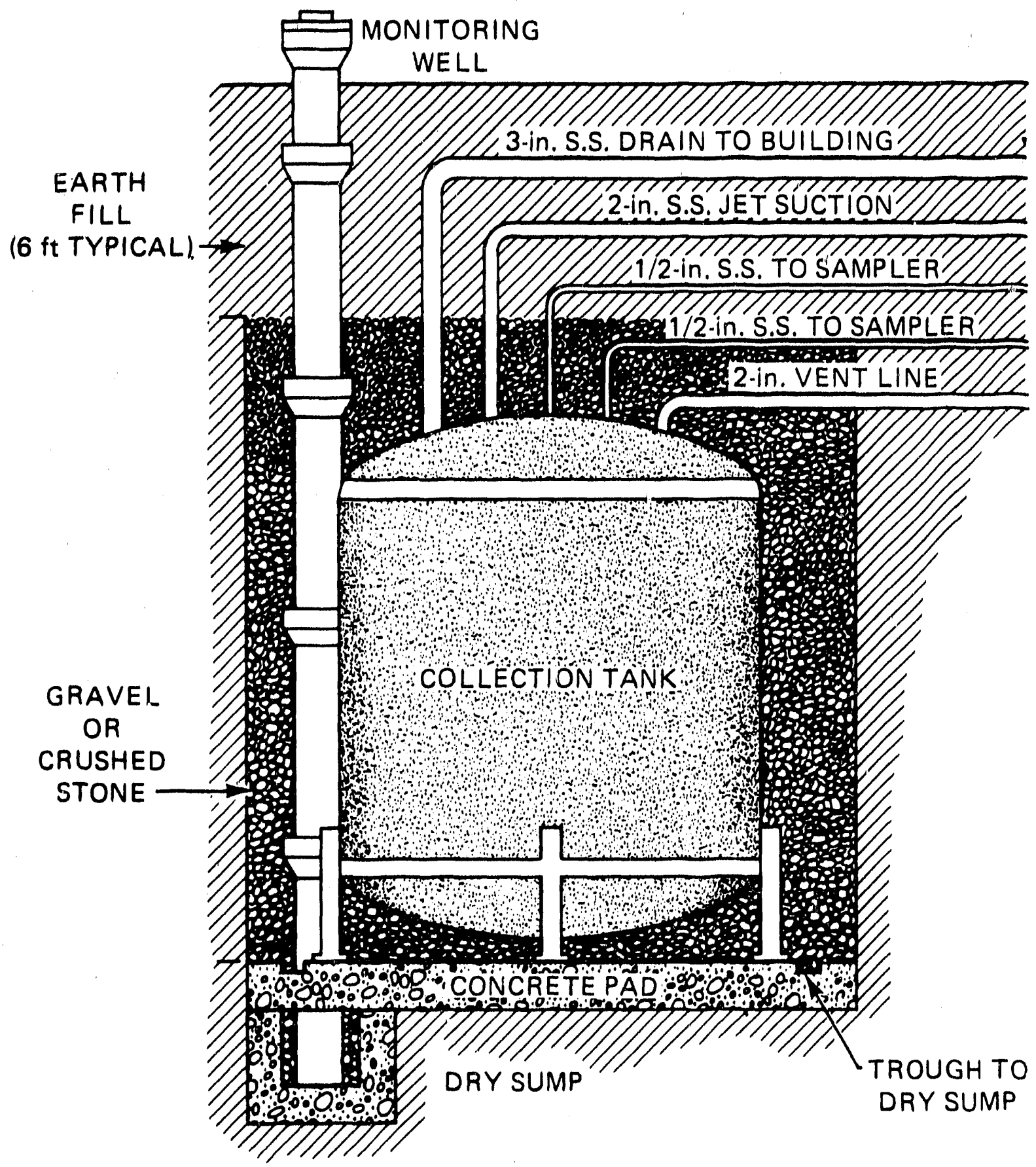

Fig. 3. Typical stainless steel collection tank installation. 
Table 1. Data on concrete (gunite) waste tanks.

\begin{tabular}{|c|c|c|c|c|c|c|}
\hline $\begin{array}{l}\text { TANK DESIGMATION } \\
\text { Number }\end{array}$ & $W-11$ & $W-1$ & $w-2$ & $T H-4$ & $H-3$ & $W-4$ \\
\hline Name & & & & & & \\
\hline Date Installed & 1943 & 1943 & 1943 & 1943 & 1943 & 1943 \\
\hline Date Takerl Out of Use & & & & & & \\
\hline Reason & Leaks & Leaks & Leaks & $\begin{array}{l}\text { Filled } \\
\text { with } \\
\text { Sludge }\end{array}$ & $\begin{array}{l}\text { Collects } \\
\text { Surface } \\
\text { Water }\end{array}$ & $\begin{array}{l}\text { Coliects } \\
\text { Surface } \\
\text { woter }\end{array}$ \\
\hline Major Use & $\begin{array}{l}\text { Collect } \\
\text { \& Monitor } \\
\text { Bldg } 3550 \\
\text { Various } \\
\text { Waste }\end{array}$ & $\begin{array}{l}\text { Collect } \\
\text { \& Process } \\
\text { Lia.Wst. } \\
\text { Vortous } \\
\text { Bldgs. }\end{array}$ & $\begin{array}{l}\text { Collect \& } \\
\text { Process } \\
\text { Liq.Wst. } \\
\text { Various } \\
\text { Bidgs. }\end{array}$ & $\begin{array}{l}\text { Collect } \\
\text { Bldg. } 3550 \\
\text { Irradiat- } \\
\text { ed Thortum } \\
\text { \& Uranium } \\
\text { Waste }\end{array}$ & $\begin{array}{l}\text { Collect } \\
\text { Metal } \\
\text { Waste }\end{array}$ & $\begin{array}{l}\text { Collect } \\
\text { Metal } \\
\text { Waste }\end{array}$ \\
\hline Capacity (gal) & 1,500 & 4,800 & 4.800 & 14,000 & 42,500 & 42,500 \\
\hline Matertals & Gunite & Gunite & Guntte & Guntte & Gunite & Gunite \\
\hline Diameter 1.D. $(f t)$ & 8.0 & 12 & 12 & 20 & 25 & 25 \\
\hline Height Center ( $f t$ ) & 5.5 & 9.5 & 9.5 & 9.35 & 14.5 & 14.5 \\
\hline O side (ft) & 4.5 & 8 & 8 & 6.6 & 12 & 12 \\
\hline Wall Thickness (in.) & $5^{l}$ & 5 & 5 & 5 & 5 & 5 \\
\hline Roof Thickness (in.) & 3 & $31 / 2$ & $31 / 2$ & $31 / 2$ & $31 / 2$ & $31 / 2$ \\
\hline Cover - Material & So11 & Soll & So11 & Sot1 & Soll & Soll \\
\hline - Thtckness $(\mathrm{ft})$ & 6 & 6 & 6 & 6 & 6 & 6 \\
\hline Foundation Depth $(f t)$ & 12 & 16.5 & 16.5 & 15.52 & 14.75 & 14.75 \\
\hline Depth of Contents $(\mathrm{m})$; & & & & & & \\
\hline Water: & 0.3 & 0.6 & 0.45 & 2.0 & 2.3 & 1.2 \\
\hline Sediment: & 0.05 & $\cdot$ & 0.3 & 1.1 & 0.45 & 0.6 \\
\hline $\begin{array}{l}\text { Contamination and Radiation } \\
\text { (See also Table } 5 \text { ) }\end{array}$ & $\begin{array}{l}\text { Highiy } \\
\text { Contam. } \\
0.2 \mathrm{mr} / \mathrm{hr} \\
0 \text { lev/tind. }\end{array}$ & $\begin{array}{l}\text { Highly } \\
\text { Contam. } \\
\text { Inter- } \\
\text { nally }\end{array}$ & $\begin{array}{l}\text { Highly } \\
\text { Contam. } \\
4 \mathrm{mr} / \mathrm{hr} \text {. } \\
\text { ground } \\
\text { level }\end{array}$ & $\begin{array}{l}\text { Drywell } \\
\text { sifghti. } \\
\text { Contem. }\end{array}$ & $\begin{array}{l}10 \mathrm{mr} / \mathrm{hr} \\
\text { p level } \\
\text { indica- } \\
\text { tor }\end{array}$ & $\begin{array}{l}1.0 \mathrm{mr} / \mathrm{hr} \\
\text { e level } \\
\text { indica- } \\
\text { tor }\end{array}$ \\
\hline Butldings Served & 3550 & $\begin{array}{l}\text { Liq.Wst. } \\
\text { Various } \\
\text { Factli- } \\
\text { ties }\end{array}$ & $\begin{array}{l}\text { Liq.Wst. } \\
\text { Various } \\
\text { Factili- } \\
\text { ties }\end{array}$ & 3550 & 3019 & 3019 \\
\hline Tank Drawings & $W-56866$ & $W-83336$ & $W-83336$ & A-56869 & $H-83336$ & $W-83336$ \\
\hline Related Drawings & $\begin{array}{l}W-68343 \\
W-56868 \\
W-68331 \\
W-690\end{array}$ & $\begin{array}{l}W-68332 \\
W-68331 \\
W-68343\end{array}$ & $\begin{array}{l}W-68332 \\
W-68331 \\
W-68343\end{array}$ & $\begin{array}{l}W-69344 \\
W-65123\end{array}$ & $\begin{array}{l}W-68333 \\
W-68331 \\
W-68343\end{array}$ & $\begin{array}{l}W-68333 \\
W-68331 \\
W-6834 i\end{array}$ \\
\hline Conments \& Notes & $\begin{array}{l}\text { Wst coll. } \\
\text { Monitering } \\
\text { Tank from } \\
\text { Various } \\
\text { Researeh } \\
\text { Labs } \\
\text { Bldg } 3550\end{array}$ & & & $\begin{array}{l}\text { No outlat } \\
\text { or } \\
\text { pit }\end{array}$ & & \\
\hline ORNL Atlas Sht No & 25 & 25 & $2 b$ & 33 & 25 & 25 \\
\hline Coordinates $N$ & 21,865 & 22,210 & 22,210 & 21,760 & 22,180 & 22,180 \\
\hline Coordinates E & 31,050 & 20,809 & 30,830 & 31,515 & 30,885 & 30,920 \\
\hline
\end{tabular}




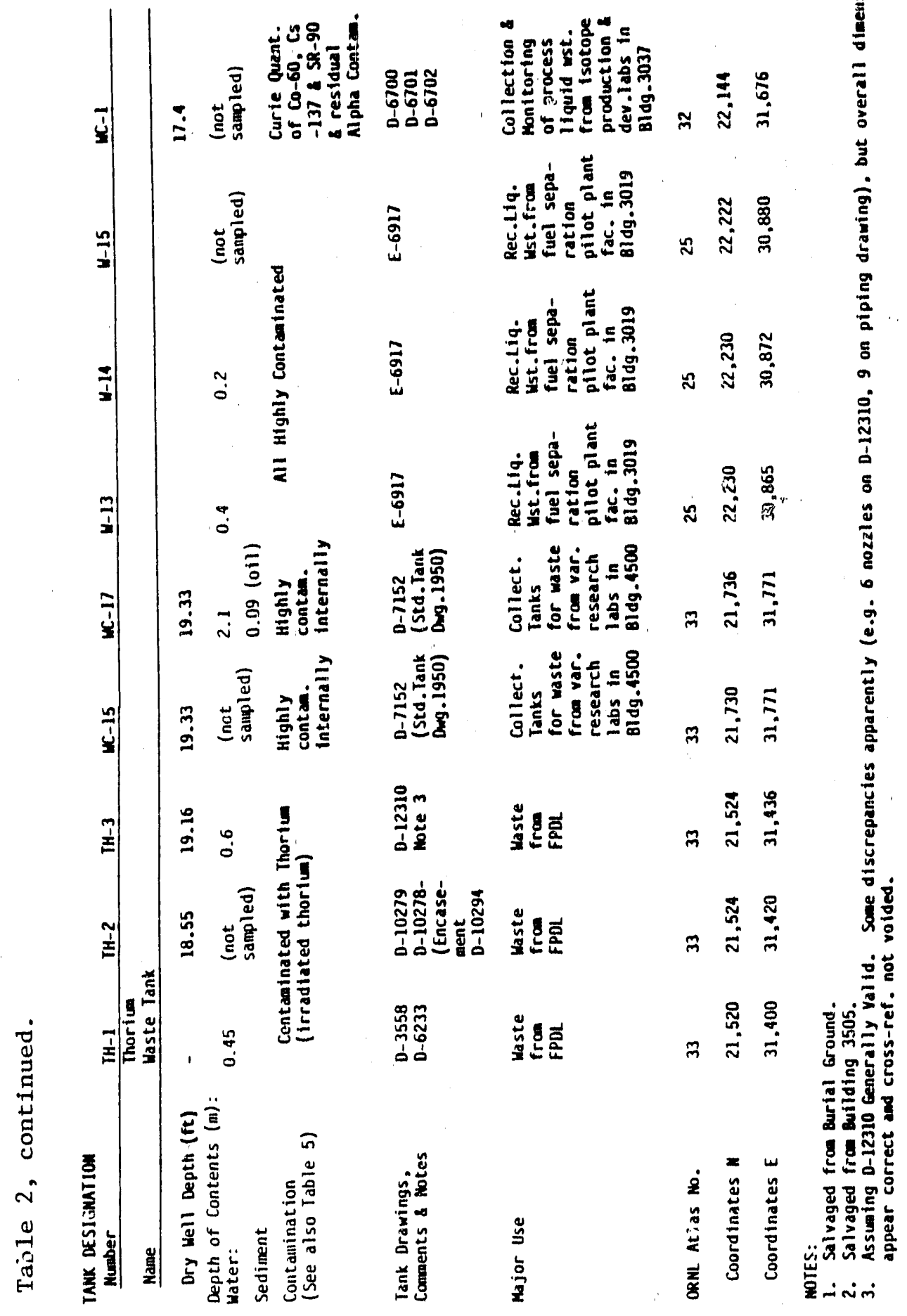




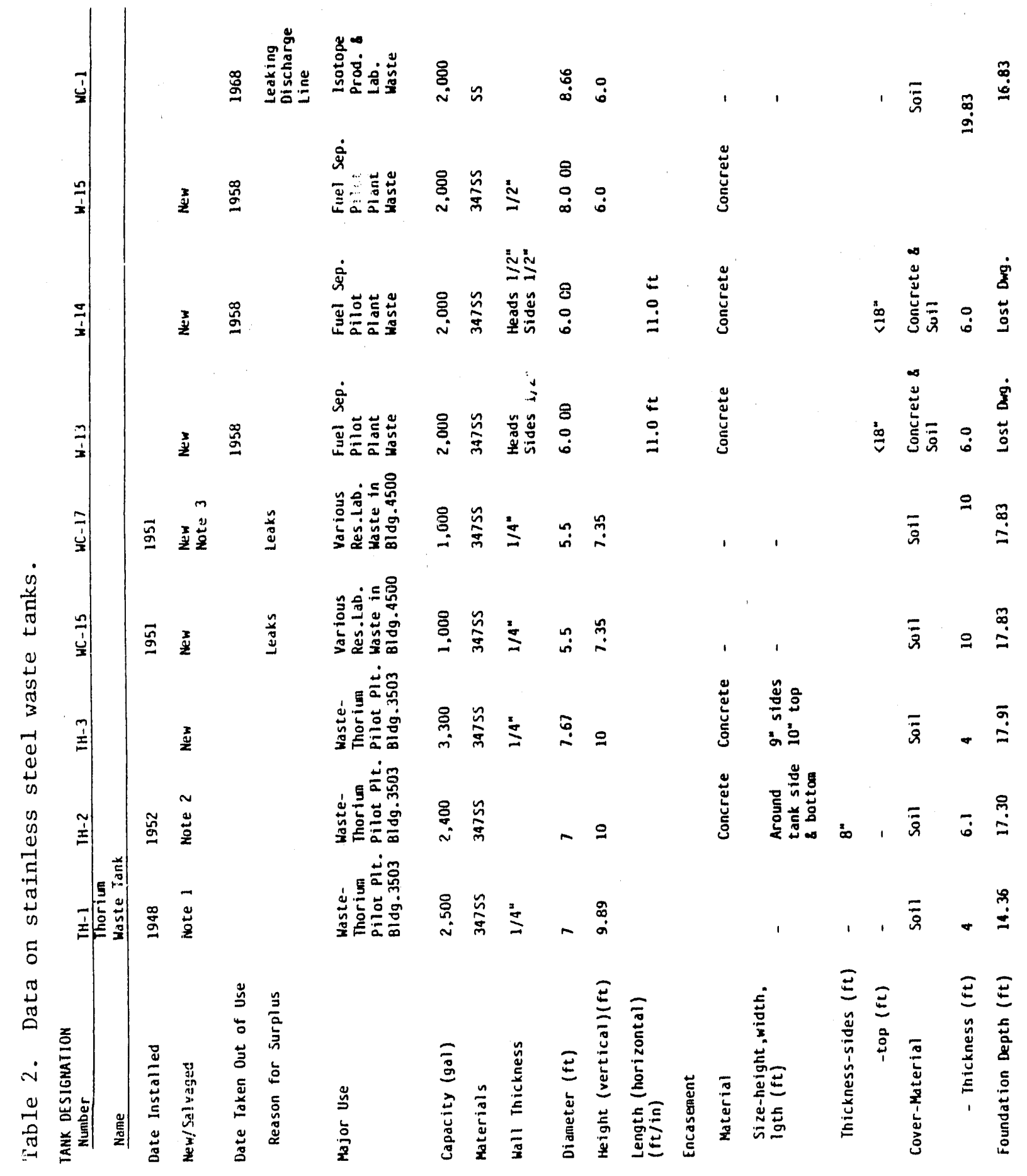


reference to the tank floor at the center, , and a nominal volume of $4,800 \mathrm{gal}$. The tank dome of each rises an additional $11 / 2 \mathrm{ft}$ at the center, has no internal supports, and is covered with aboit $6 \mathrm{ft}$ of compacted dirt as genericaliy 1llustrated (Fig. 2) for all underground concrete tanks. Each Gunfte tank sidewall is approximately 5 in. thick, and the tank dome is around $31 / 2 \mathrm{ln}$. thick. The tanks do not have an interfor metal liners. Their roofs and side walls incorporate $3 / 8 \mathrm{in}$, and $1 / 2$ in. reinforcing steel with turnbuckles. A block of concrete extends over a portion of the top of each tank and surrounds the penetration openings .

The two plug valve pits on the north side of tank $W-2$ have overall dimensions of $3.7 \times 5 \mathrm{ft}$ and $4 \times 5 \mathrm{ft}$. Helghts are 5.5 and $7.5 \mathrm{ft}$, respectively. The shorter one is shown by the driwing to have $5 \mathrm{ft}$ of soil cover but both pits extend to the surface. A standard valve pit south of tank $W-2$ has regular valves. This valve pit has overall dimensions of $5.3 \times 7.3 \mathrm{ft}$ and, height of $13.3 \mathrm{ft}$. This pit extends to the surface and valve stems penetrate the cover.

2.1.3 Tank History, Use, and Contents. During the 35 years the Gunite waste tanks have been in service, they have recelved LLW (formerly called ILW) waste primarily from Building 3019, a radiochemical processing facility. 2,3 Except for rainwater and possibly solid deposits, the tanks are believed to be empty. The tanks are highly contaminated and out of service due to leaks.

Tank $W-1$ most likely received both metal waste with highly radioactive source and fissionable material as well as hot chemical waste which contains no source of fissionable material. 
Tank W-2 was used for overflow from Tank $W-1$ and potentlally encountered the same materials.

The valve pits handle the same material as tanks $W-1$ and $W-2$ and were abandoned at the same time.

2.1.4 Tank Access and Sampling. The design and construction of the W-1. and $W-2$ Gunite tanks left only one $30 \mathrm{ln}$. manhole and a $12 \mathrm{ln}$. diameter pipe for access to the interior of each tank for inspection, sampling, and liquid level measurement. Approximately $6 \mathrm{ft}$ of soll covers the tanks. The two north most valve pits extend to the surface and are covered with a removable cover. The south pit has a flxed concrete cover with a 26 in. manhole cover. The dry wells also have 26 in. manhole covers.

2.1.5 Radiological Characterization. The preliminary radiological characterization results for tanks $W-1$ and $W-2^{4}$ indicates redidual contents of 3900 and 50001 , respectively. Collected sediments account for 3000 of the 50001 of waste in tank $W-2$. The total radionuclide inventory is 0.1 $\mathrm{C} 1$ for tank $\mathrm{W}-1$ and $220 \mathrm{Ci}$ for tank $\mathrm{W}-2$. The contaminants in tank $W-1$ are nainly ${ }^{137} \mathrm{Cs}$ and ${ }^{90} \mathrm{Sr}$; ${ }^{238} \mathrm{Pu}$ is the principal radionuclide found in tank $W-2$. The survey lists $W-2$ as : ne of the three tanks of those sampled containing the most significant radioactivity. Total inventories of individual radionuclides found in tanks $W-1$ and $W-2$, as well as the other tanks covered in this study, are listed $:$ Table 3 and further summarized in Table 4. Radiation levels inside the tanks are summarized in Table 5. The general beta-gamma background levels found in tank $3-1$ and $\mathrm{W}-2$ are 330 and $1800 \mathrm{mrad} / \mathrm{h}$, respectively. 
Table 3. Radiological inventories of the contents of eleven waste tanks.

\begin{tabular}{|c|c|c|c|c|c|c|c|}
\hline \multirow[b]{2}{*}{$\begin{array}{c}\text { Tank } \\
\text { (onpaolty) }\end{array}$} & \multicolumn{3}{|c|}{ Thuk eoutents } & \multirow[b]{2}{*}{$\begin{array}{l}\text { Major } \\
\text { redionaclides }\end{array}$} & \multirow{2}{*}{$\begin{array}{c}\text { Concozitratlone } \\
(\mathrm{Bq} / \mathrm{wL} \text { or } \\
\mathrm{Bq} / \mathrm{s})\end{array}$} & \multirow{2}{*}{\multicolumn{2}{|c|}{ Ierentory }} \\
\hline & Tron & $\begin{array}{l}\text { Dopls } \\
\text { (a) }\end{array}$ & $\begin{array}{c}\text { Vol }=0 \\
\text { (L) }\end{array}$ & & & & \\
\hline \multirow[t]{2}{*}{$\begin{array}{l}7-11 \\
\left(3.8 \times 10^{3} \mathrm{~L}\right)\end{array}$} & Wator & 0.3 & 1,000 & $\begin{array}{l}137 \mathrm{Cs} \\
90 \mathrm{sr} \\
238 \mathrm{Pu} \\
239 \mathrm{Pr} \\
241 \mathrm{Am} \\
244 \mathrm{Om}\end{array}$ & $\begin{array}{l}1.1 \\
2.8 \\
2.3 \\
1.1 \\
\langle 1.0 \\
<1.0\end{array}$ & $\begin{array}{r}0.001 \\
0.003 \\
0.002 \\
0.001 \\
<0.001 \\
<0.001\end{array}$ & $\begin{array}{l}0.03 \\
0.08 \\
0.05 \\
0.03 \\
<0.03 \\
<0.03\end{array}$ \\
\hline & slodso & 0.03 & 170 & Ns $^{\circ}$ & N8 & NS & NE \\
\hline \multirow[t]{2}{*}{$\begin{array}{l}(3-17 \\
\left(3.9 \times 10^{3} \mathrm{~L}\right)\end{array}$} & 011 & 0.09 & $1,500 \mathrm{~d}$ & $\begin{array}{l}137 \mathrm{Cu} \\
90 \mathrm{Sr} \\
60 \mathrm{Co} \\
154_{\mathrm{Bu}} \\
238 \mathrm{Pu} \\
239 \mathrm{~Pa} \\
241_{\mathrm{Au}} \\
244 \mathrm{Cu}\end{array}$ & $\begin{array}{l}2.8 \\
24 \\
2.8 \\
1.5 \\
40 \\
20 \\
37 \\
53\end{array}$ & $\begin{array}{l}0.004 \\
0.04 \\
0.004 \\
0.003 \\
0.06 \\
0.03 \\
0.06 \\
0.08\end{array}$ & $\begin{array}{l}0.1 \\
1 \\
0.1 \\
0.06 \\
2 \\
0.8 \\
2 \\
2\end{array}$ \\
\hline & Wator & 2.1 & 3,600 & 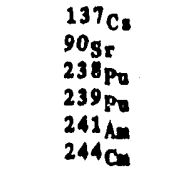 & $\begin{array}{c}4.6 \\
18 \\
1.7 \\
1.0 \\
\langle 1.0 \\
\langle 1.0\end{array}$ & $\begin{array}{l}0.02 \\
0.07 \\
0.006 \\
0.004 \\
0.004 \\
<0.004\end{array}$ & $\begin{array}{l}0.3 \\
2 \\
0.2 \\
0.1 \\
0.1 \\
0.1\end{array}$ \\
\hline $\begin{array}{l}n-1 \\
\left(9.7 \times 10^{3} L\right)\end{array}$ & Weter & 0.45 & 1.800 & $\begin{array}{l}137 \mathrm{Co} \\
90 \mathrm{sr} \\
60 \mathrm{Co} \\
238 \mathrm{Pz} \\
239 \mathrm{Pr} \\
241 \mathrm{Am} \\
241 \mathrm{Cm} \\
232 \mathrm{mb}\end{array}$ & $\begin{array}{c}9.5 \times 10^{3} \\
1.2 \times 10^{4} \\
2.7 \times 10^{2} \\
1.9 \\
1.2 \\
<1.0 \\
<1.0 \\
0.07\end{array}$ & $\begin{array}{l}20 \\
22 \\
0.5 \\
0.003 \\
0.002 \\
0.002 \\
0.002 \\
0.0001\end{array}$ & $\begin{array}{l}500 \\
600 \\
10 \\
0.09 \\
0.06 \\
0.05 \\
0.05 \\
0.003\end{array}$ \\
\hline 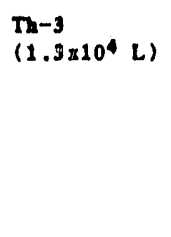 & Wator & 0.6 & 2.600 & $\begin{array}{l}137 \mathrm{Cs} \\
60 \mathrm{Co} \\
90 \mathrm{Sr} \\
238 \mathrm{Ps} \\
239 \mathrm{Pw} \\
241 \mathrm{Am} \\
244 \mathrm{Cm} \\
232 \mathrm{mb}\end{array}$ & $\begin{array}{c}8.3 \times 10^{3} \\
6.5 \\
7.9 \times 10^{3} \\
1.1 \\
1.3 \\
\langle 1.0 \\
<1.0 \\
0.02\end{array}$ & $\begin{array}{c}22 \\
0.02 \\
20 \\
0.003 \\
0.003 \\
<0.003 \\
<0.003 \\
0.00005\end{array}$ & $\begin{array}{c}600 \\
0.3 \\
600 \\
0.08 \\
0.09 \\
<0.07 \\
<0.07 \\
0.001\end{array}$ \\
\hline \multirow[t]{2}{*}{$\begin{array}{l}n-4 \\
\left(3.4 \times 10^{4} L\right)\end{array}$} & Wator & 2.0 & 37.000 & $\begin{array}{l}137 \mathrm{Cu} \\
90 \mathrm{gr} \\
238 \mathrm{Pd} \\
239 \mathrm{Pu} \\
2111_{\mathrm{Am}} \\
244 \mathrm{~cm} \\
232 \mathrm{Th}\end{array}$ & $\begin{array}{l}7.6 \\
0.26 \\
1.7 \\
1.7 \\
\langle 1.0 \\
<1.0 \\
0.01\end{array}$ & $\begin{array}{c}0.3 \\
0.01 \\
0.06 \\
0.06 \\
<0.04 \\
<0.04 \\
0.0004\end{array}$ & $\begin{array}{l}8 \\
0.3 \\
2 \\
2 \\
41 \\
41 \\
0.01\end{array}$ \\
\hline & SIodgo & 1.1 & 21,000 & $\begin{array}{l}137 \mathrm{Cs} \\
90 \mathrm{Sr} \\
238 \mathrm{Pu} \\
239 \mathrm{~Pa} \\
241_{\mathrm{Am}} \\
244 \mathrm{Cm}\end{array}$ & $\begin{array}{l}6.6 \times 10^{2} \\
92 \\
14 \\
27 \\
80 \\
60\end{array}$ & $\begin{array}{l}20 \\
2 \\
0.4 \\
0.7 \\
2 \\
2\end{array}$ & $\begin{array}{l}500 \\
60 \\
10 \\
20 \\
50 \\
40\end{array}$ \\
\hline $\begin{array}{l}\nabla-1 \\
\left(1.9 \times 10^{4} L\right)\end{array}$ & Woter & 0.6 & 3.900 & 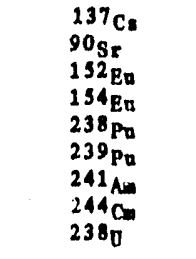 & $\begin{array}{c}1.7 \times 10^{2} \\
8.4 \times 10^{2} \\
2.6 \times 10^{2} \\
3.2 \\
1.8 \\
2.9 \\
1.7 \\
13 \\
10.1\end{array}$ & $\begin{array}{l}0.7 \\
3.3 \\
1 \\
0.02 \\
0.007 \\
0.01 \\
0.007 \\
0.05 \\
0.0004\end{array}$ & $\begin{array}{l}20 \\
90 \\
30 \\
0.5 \\
0.2 \\
0.3 \\
0.2 \\
1 \\
0.01\end{array}$ \\
\hline
\end{tabular}


Table 3, continued.

\begin{tabular}{|c|c|c|c|c|c|c|c|}
\hline \multirow{3}{*}{$\begin{array}{c}\text { Tank } \\
\text { (oupaciey) }\end{array}$} & \multicolumn{3}{|c|}{ Tank contones } & \multirow{3}{*}{$\begin{array}{l}\text { Major } \\
\text { redionoolides }\end{array}$} & \multirow{3}{*}{$\begin{array}{c}\text { Concontratlon" } \\
(B q / m L \text { or } \\
B q / s)\end{array}$} & \multirow{2}{*}{\multicolumn{2}{|c|}{ Inventory }} \\
\hline & \multirow[t]{2}{*}{ Type } & \multirow{2}{*}{$\begin{array}{c}\text { Dopth } \\
(=)\end{array}$} & \multirow{2}{*}{$\begin{array}{l}\text { Vol } m=0 \\
\text { (L) }\end{array}$} & & & & \\
\hline & & & & & & $(a b q)^{b}$ & $(\mathbf{a C d})$ \\
\hline \multirow{17}{*}{$\left(1.9 \times 10^{4} L\right)$} & Water & 0.45 & 3.000 & $137 \mathrm{Cs}$ & 13 & 0.04 & 1 \\
\hline & & & & $\begin{array}{l}90 \mathrm{sr}_{\mathrm{r}} \\
238_{\mathrm{Pv}}\end{array}$ & $\begin{array}{c}5.1 \times 10^{2} \\
1.9\end{array}$ & $\begin{array}{l}2 \\
0.006\end{array}$ & $\begin{array}{l}4 \\
0.2\end{array}$ \\
\hline & & & & $239 \mathrm{Pu}$ & 5.1 & 0.02 & 0.4 \\
\hline & & & & $241 \mathrm{Am}$ & 2.7 & 0.008 & 0.2 \\
\hline & & & & $244 \mathrm{com}$ & 4.1 & 0.01 & 0.3 \\
\hline & & & & $233 \mathrm{U}$ & 0.9 & 0.003 & 0.07 \\
\hline & & & & 2380 & 0.2 & 0.0006 & 0.02 \\
\hline & Sl od Bo & 0.3 & 2.000 & ${ }_{90}^{137} \mathrm{Cs}$ & $\begin{array}{l}1.7 \times 10^{5} \\
2.1 \times 10^{5}\end{array}$ & $\begin{array}{l}400 \\
300\end{array}$ & $\begin{array}{l}10,000 \\
10,000\end{array}$ \\
\hline & & & & $\begin{array}{l}90 \mathrm{Sr} \\
60 \mathrm{Co}\end{array}$ & $\begin{array}{l}2.1 \times 10^{3} \\
3.7 \times 10^{2}\end{array}$ & $\begin{array}{r}300 \\
1\end{array}$ & $\begin{array}{r}10.000 \\
40\end{array}$ \\
\hline & & & & $238 \mathrm{pu}$ & $2.8 \times 10^{60}$ & 7,000 & 200,000 \\
\hline & & & & $239 \mathrm{Pu}$ & & 80 & 2,000 \\
\hline & & & & $241 \mathrm{Am}$ & $3.0 \times 10^{4}$ & 100 & 3,000 \\
\hline & & & & $\begin{array}{l}2440 \mathrm{~cm} \\
1520\end{array}$ & $1.3 \times 10^{3}$ & 3 & Bo \\
\hline & & & & $\begin{array}{l}152 \mathrm{Eu} \\
1548 \mathrm{~B}\end{array}$ & $7.3 \times 10^{4}$ & 200 & 5.000 \\
\hline & & & & $135_{\mathrm{Eu}}^{\mathrm{Eu}}$ & $\begin{array}{l}1.2 \times 10^{4} \\
4.8 \times 10^{2}\end{array}$ & $\begin{array}{r}30 \\
1\end{array}$ & $\begin{array}{r}800 \\
30\end{array}$ \\
\hline & & & & $233_{\mathrm{v}}$ & $1.2 \times 10^{2}$ & 0.3 & 8 \\
\hline & & & & 2380 & 4.6 & 0.01 & 0.3 \\
\hline \multirow{8}{*}{$\left(1.6 \times 10^{5} \mathrm{~L}\right)$} & Tater & 2.3 & 84,000 & ${ }^{137} \mathrm{C}$ & $4.3 \times 10^{2}$ & 40 & 1,000 \\
\hline & & & & $90 \mathrm{~S} x$ & 14 & 1 & 30 \\
\hline & & & & $238 \mathrm{pu}$ & 2.9 & 0.2 & 7 \\
\hline & & & & ${ }_{239}^{239}$ & 1.4 & 0.1 & 3 \\
\hline & & & & $\begin{array}{l}241 \mathrm{Am} \\
244 \mathrm{Cm}\end{array}$ & $\begin{array}{l}1.7 \\
4.7\end{array}$ & $\begin{array}{l}0.1 \\
0.4\end{array}$ & $\begin{array}{r}4 \\
10\end{array}$ \\
\hline & & & & $233_{0}$ & 4.2 & 0.4 & 10 \\
\hline & & & & 2380 & 1.0 & 0.08 & 2 \\
\hline & S1 adse & 0.45 & $16,000^{d}$ & NS & NS & NS & NS \\
\hline \multirow{16}{*}{$\begin{array}{l}N-4 \\
\left(1.6 \times 10^{5} L\right)\end{array}$} & Dater & 1.2 & 44,000 & ${ }^{137} \mathrm{Cs}$ & $7.5 \times 10^{2}$ & 33 & 900 \\
\hline & & & & $90 \mathrm{~S} x$ & $3.0 \times 10^{2}$ & 13 & 400 \\
\hline & & & & $\begin{array}{l}238 \mathrm{Pu} \\
239 \mathrm{pq}\end{array}$ & 1.8 & 0.08 & 2.1 \\
\hline & & & & $241 \mathrm{Am}$ & $\begin{array}{l}0.8 \\
2.7\end{array}$ & $\begin{array}{l}0.04 \\
0.1\end{array}$ & $\frac{1}{3}$ \\
\hline & & & & $244 \mathrm{~cm}$ & 2.1 & $\therefore 1$ & $\mathbf{3}$ \\
\hline & & & & $233 \mathrm{v}$ & 12 & 0.3 & 14 \\
\hline & & & & 2350 & 0.8 & 0.04 & 1 \\
\hline & & & & ${ }^{238} 0$ & 13 & 0.6 & 20 \\
\hline & s1 ndge & 0.6 & 22,000 & $137 \mathrm{C}$ & $1.4 \times 10^{5}$ & 4,000 & 100.000 \\
\hline & & & & $\begin{array}{l}60 \mathrm{Co} \\
90{ }_{\mathrm{Sr}}\end{array}$ & $\begin{array}{c}28 \\
2.0 \times 10^{5}\end{array}$ & $\begin{array}{c}0.7 \\
3.000\end{array}$ & $\begin{array}{r}20 \\
100,000\end{array}$ \\
\hline & & & & $238 \mathrm{Pu}$ & Bo & 2 & \\
\hline & & & & $239 \mathrm{Pu}$ & $2.4 \times 10^{3}$ & 60 & 2,000 \\
\hline & & & & 241 Ap & $1.3 \times 10^{2}$ & 3 & 90 \\
\hline & & & & 2440 & $2.4 \times 10^{2}$ & 6 & 200 \\
\hline & & & & $233_{0}$ & $2.2 \times 10^{3}$ & 60 & 2,000 \\
\hline & & & & $\begin{array}{l}2350 \\
2380\end{array}$ & $\begin{array}{l}1.1 \times 10^{2} \\
2.2 \times 10^{3}\end{array}$ & $\begin{array}{r}3 \\
60\end{array}$ & $\begin{array}{r}80 \\
2.000\end{array}$ \\
\hline \multirow{11}{*}{$\begin{array}{l}7-13 \\
\left(7.8 \times 10^{3} \mathrm{~L}\right)\end{array}$} & & & & & & & \\
\hline & Mater & 0.4 & 1.700 & $\begin{array}{l}137 \mathrm{c} \text {. } \\
60 \mathrm{Co}\end{array}$ & $\begin{array}{l}7.1 \times 10^{5} \\
2.6 \times 10^{2}\end{array}$ & 1,000 & $\begin{array}{r}30.000 \\
10\end{array}$ \\
\hline & & & & $\begin{array}{l}90 \mathrm{Co} \\
9 \mathrm{Sr}\end{array}$ & $7.4 \times 10^{6}$ & 10,000 & 300,000 \\
\hline & & & & $\begin{array}{l}134 \mathrm{Eg} \\
\mathrm{B}\end{array}$ & $2 \times 10^{3}$ & 20.00 & 100 \\
\hline & & & & $238 \mathrm{Pu}$ & $9.6 \times 10^{2}$ & 1 & 30 \\
\hline & & & & $239 \mathrm{pu}$ & 38 & 0.1 & 3 \\
\hline & & & & 241 A & $3.0 \times 10^{2}$ & 0.5 & 10 \\
\hline & & & & $244 \mathrm{cos}$ & & 0.1 & 3 \\
\hline & & & & $233 \mathrm{v}$ & 4.6 & 0.008 & 0.2 \\
\hline & & & & $235_{0}$ & 0.4 & 0.0007 & 0.02 \\
\hline & & & & 2380 & 2,1 & 0.004 & 0.1 \\
\hline
\end{tabular}


Table 3, continued.

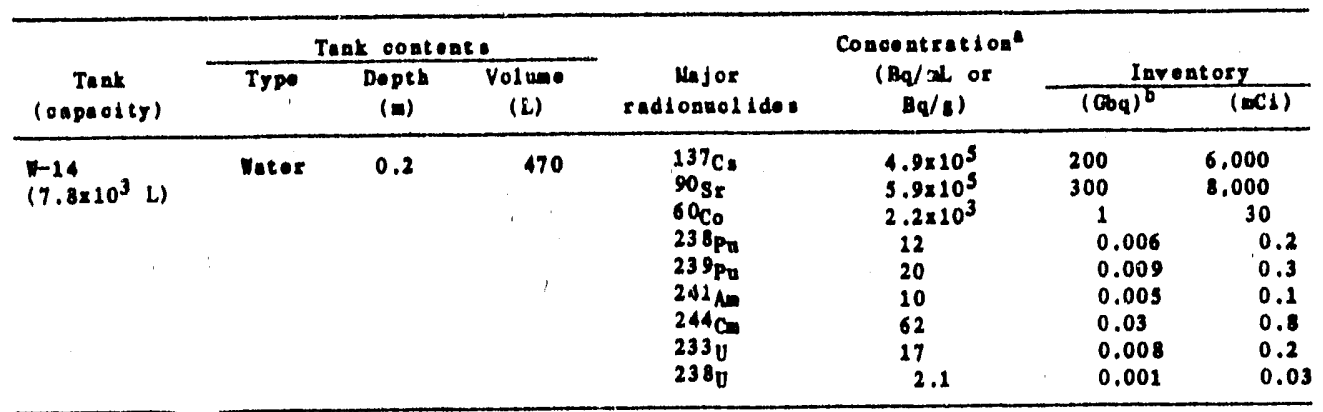

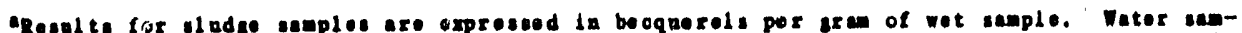
ple rearlta are is bo oqurele per allililitex.

$b_{1} \mathrm{~Bq}=27 \mathrm{pCl}$.

oNo canplo onn be collected.

dTank wC-17 is fllled with water and oil. The vol one of oll could be orerostimated.

- Deta que iomable. Asother seaple vill bo taken and amalyeod. 
Table 4. Summary of estimated total radiological inventory and mafor radionuclides in each tank.

\begin{tabular}{|c|c|c|c|c|c|c|c|}
\hline \multirow[b]{2}{*}{ Tank } & \multirow{2}{*}{$\begin{array}{l}\text { Type of } \\
\text { content }\end{array}$} & \multicolumn{2}{|c|}{ Total inventory } & \multicolumn{2}{|c|}{ Percentage } & \multicolumn{2}{|c|}{ of radionuolidos } \\
\hline & & $(\mathrm{GBq})$ & (Ci) & $137 \mathrm{Cs}$ & $90 \mathrm{Sr}$ & TRU & Others \\
\hline \multirow{3}{*}{$\begin{array}{r}W-11 \\
W C-17\end{array}$} & Water & 0.009 & 0.0003 & 12 & 30 & 58 & Trace \\
\hline & oil & 0.3 & 0.008 & 1 & 13 & 84 & 2 \\
\hline & Water & 0.1 & 0.003 & 17 & 66 & 17 & Trace \\
\hline$T h-1$ & Water & 40 & 1 & 43 & 56 & Trace & 1 \\
\hline $\mathrm{Th}-3$ & Hater & 42 & 1 & 51 & 49 & Trace & Traco \\
\hline \multirow[t]{2}{*}{$\mathrm{Th}-4$} & Pater & 0.5 & 0.01 & 57 & 2 & 41 & Trace \\
\hline & S1 udge & 24 & 0.7 & 71 & 10 & 19 & Trace \\
\hline$V i-1$ & Hater & 5.0 & 0.1 & 13 & 65 & 2 & 20 \\
\hline \multirow[t]{2}{*}{$y-2$} & Water & 1.6 & 0.0 & 2 & 95 & 3 & Trace \\
\hline & S1udge & 8,000 & 220 & 5 & 6.3 & 86 & 3 \\
\hline$W-3$ & Hater & 39 & 1 & 94 & 3 & 2 & 1 \\
\hline \multirow[t]{2}{*}{$W-4$} & Water & 48 & 1 & 69 & 28 & 1 & 2 \\
\hline & Sludge & 9,200 & 200 & 40 & 58 & 1 & 1 \\
\hline$W-13$ & Water & 14,000 & 400 & 9 & 91 & Trace & Trace \\
\hline$V-14$ & Water & 500 & 10 & 45 & 55 & Trace & Trace \\
\hline
\end{tabular}




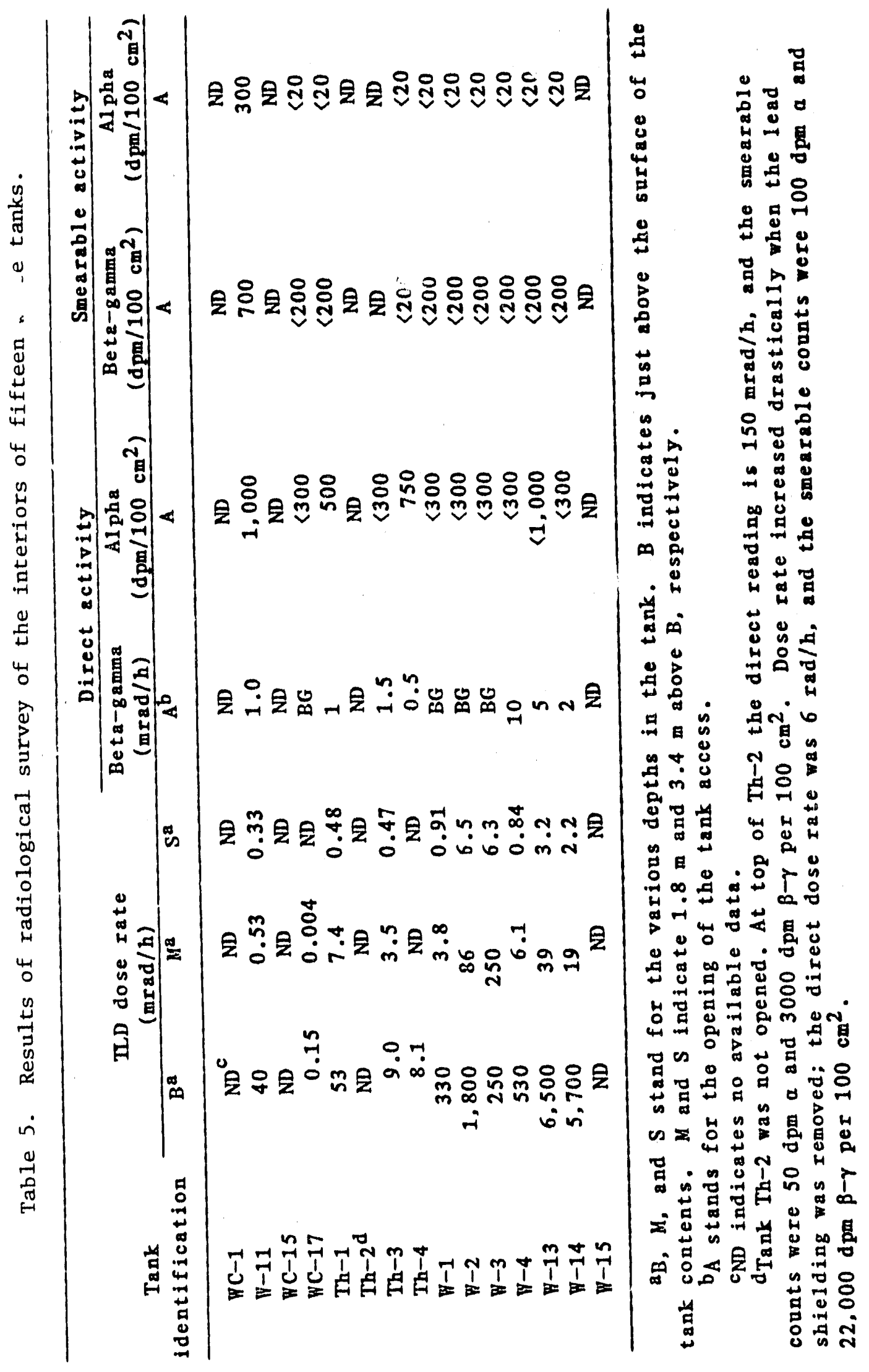


The major radionuclides found in the soll at the north tank farm are ${ }^{137} \mathrm{Cs},{ }^{90} \mathrm{Sr},{ }^{60} \mathrm{Co}$ and ${ }^{232} \mathrm{Th}$. Trace quantities of other radionuclides were also observed. Soll contamination levels around tanks $W-1$ and $W-2$ were the highest found in the preliminary characterization.

\subsection{Intermediate Size Concrete Tanks $W-3$ and $W-4$}

\subsubsection{Location and Adfacent Facilities. These tanks were constructed} in the North Tank Farm which is located in the approximate center of the ORNL facilities at the $X-10$ site. Tanks $W-3$ and $W-4$ are underground and were constructed in 1943 of relnforced Gunfte. The tanks are approximately $35 \mathrm{ft}$ apart center-to-center. A plug valve type valve plt (not visible at grade) is located on the north side of tanks $W-3$ and $W-4$. A standard valve pit is located on the south side of $w-3$. Each tank has an adjacent dry wel1.

2.2.2 Tank Construction. The $W-3$ and $W-4$ Gunite tanks have an inside diameter of $25 \mathrm{ft}$, a vertical sidewall height of $12 \mathrm{ft}$ (with reference to the tank floor at the center), and a nominal volume of 42,500 gals. The tank dome rises $1.5 \mathrm{ft}$ at the center, has no internal supports, and is covered with about $6 \mathrm{ft}$ of compacted dirt (see general lllustration in Fig. 2.) The Gunite tank sidewall is $5 \mathrm{1n}$. thick and the tank dome is

$3 \mathrm{in.} \mathrm{thick}$ at the center, increasing in thickness near the tank wall. The tanks do not have interior metal 11ners. The roof and side walls incorporate $3 / 8 \mathrm{in}$. and $1 / 2 \mathrm{in}$. rednforcing steel. 
The plug valve pit located north of $W-3$ is made of concrete and has overall dimensions of $3.7 \times 5 \mathrm{ft} \times 7 \mathrm{ft}$ tall. The walls are $9 \mathrm{in}$. thick, and the pit has $5 \mathrm{ft}$ of soll cover. It is not visible from the surface. A similar size regular valve pit visible at grade is located on the south side of tank $\mathrm{W}-3$. The dry wells are standard construction. The third valve pit located northwest of tank $W-4$ has a removable metal cover.

\subsubsection{Tank History and Contents. During the 35 years the gunite} tanks $W-3$ and $W-4$ have been in service they have primarlly served to collect metal waste from Bldg. 3019, a radiochemical processing facility. 1,2 Operating procedures called for neutralizing all waste to prevent corrosive attack on the concrete. The tanks are believed to contain deposited sludge and chear water, but no waste solution. They are highly contaminated and are out of service due to collection of ground water.

Tank W-3 collected plutonlum waste streams originating in Bldg. 3019. In addition, 1954 operating procedures describes valve settings for transferring material from tank $W-14$ to $W-3$. (Tank 14 also contained metal waste and normally served the Operations Division, Radiolsotope Department.) $)^{2}$ Tank $W-3$ is estimated to have $8 \mathrm{ft}$ of water ${ }^{1}$ based on the float gauge.

Tank W-4 collected uranium waste from Bldg. 3019 but also could recelve waste from tank $W-13$. Tank $W-13$ normally served the Chemistry Division, Hot Laboratory group and collected hot chemical waste. The valve pits encountered the same materials as tanks $W-3$ and $W-4$. 
2.2.4 Tank Access and Sampling Tanks. The design and construction of the $W-3$ and $W-4$ Gunite tanks left only one $30 \mathrm{ln}$. manhole and a $12 \mathrm{ln}$. dlameter pipe for access to the interior of each tank for inspection, sampling, and liquid level measurement. Approximately $6 \mathrm{ft}$ of soll covers the tanks. The valve pits are covered with soil and only accessible by way of the valve stems.

2.2.5 Kadiological Characterization. The prellminary radiological characterization results for tanks $W-3$ and $W-4^{4}$ indicates residual contents of 100,000 and 60,0001 , respectively. The radionuclide inventory in tank W-3 was estimated to total about $1 \mathrm{CI}$, and the total inventory in tank $W-4$ was estimated th be about $200 \mathrm{Cl}$. One third of the total volume in tank W-4 is sediment, containing about $99 \%$ of the total activity in the tank. Sediment in tank $W-3$ was not sampled. The primary radionuclides found in the tanks are ${ }^{137} \mathrm{Cs}$ and ${ }^{90} \mathrm{Sr}$. Tank $\mathrm{W}-4$ is among the three tanks of those sampled contalning the most significant radioactivity. The general betagamna background levels found in tanks $W-3$ and $W-4$ are 250 and $500 \mathrm{mrad} / \mathrm{h}$, respectively. Characterization data on tanks $W-3$ and $W-4$ is summarized in Tables 3-5.

The major radionuclides observed in the soll around tanks $W-3$ and $W-4$ are ${ }^{137} \mathrm{Cs}$ and ${ }^{90} \mathrm{Sr}$. No significant concentrations of transuranics were found in the soil samples.

\subsection{Stainless Steel Tanks in North Tank Farm W-13, W-14, and W-15}

2.3.1 Location and Adjacent Facilities. Tanks $W-14, W-15$, and $W-16$ are stainless steel tanks also located in the north tank farm. ${ }^{5}$ They are burled in concrete to a depth of $71 / 2 \mathrm{ft}$. A standard valve pit is located 
Immediately north of tanks $W-3$ and $W-4$. In addition, a plug valve plt and a surplus standard valve pit are located approximately $50 \mathrm{ft}$ northwest of tank $W-13$ on the north edge of the north tank farm.

2.3.2 Tank Construction. Tanks $W-i 3$ and $W-14$ are horizontal, cylindrical, type $347 \mathrm{SCb}$ stainless steel tanks $11 \mathrm{ft}$ long by $6 \mathrm{ft}$ in dlameter, each having a capacity of approximately 2,000 gals. These tanks rest on a $16 \mathrm{ft} \times 14 \mathrm{ft}$ concrete pad. Tank $W-15$ is a vertical, cylindrical, dished top, sloped bottom, type $309 \mathrm{SCb}$ stalnless steel tank, $6 \mathrm{ft}$ high by $8 \mathrm{ft}$ diameter having a capacity of approximately 2,000 gals. $W-15$ rests on a $16 \mathrm{ft} \times 9 \mathrm{ft}$ pad adjacent to tanks $W-13$ and $W-14$. A11 three tanks are embedded in a common concrete encasement to a depth of $71 / 2 \mathrm{ft}$ above the tallest tanks. The encasement extends above ground approximately $4 \mathrm{ft}$ on the south side and $1 \mathrm{ft}$ on the north side.

The three valve pits assciclated with tanks $W-13$ through $W-15$ are concrete construction as previously described. Two of the pits are recognized at the surface but one of them has been covered over with soll or possibly removed.

2.3.3 Tank History and Content.s. Tanks $W-13, W-14$, and $W-15$ are connected to the metal waste drains in B1dg. 3019, but they collected hot chemical waste for recovery of fission products. Tank W-13 normally served the Chem1stry Division Hot Laboratory group. Tanks $W-14$ and $W-15$ normally served the Uperations Division, Radioisotope Department. 3

These tanks have been out of service since 1958. Depth of contents in $W-13$ has been estimated at less than one foot. ${ }^{4}$ 
2.3.4 Tank Access and Sampling. Access to these tanks 1s through the following service connections:

Service

Alr Sparger

Sampler

Solution Inlet

Manhole

Jet Suction

Overflow to $\mathrm{W}-3$

Vent

Float Gauge

Spare

Blanks

$\frac{\text { S1ze }}{\mathrm{W}-13 \quad \mathrm{~W}-14}$

1 in. 1 in. 1 in.

2 in. 2 in. 2 in.

2 in. 2 in. 2 in.

$16 \mathrm{ln} .16 \mathrm{in.} 17 \mathrm{l} / 2 \mathrm{in.}$

1 in. 1 in. $1 \mathrm{ln}$.

2 in. 2 in. 2 in.

2 in. 2 in. 2 in.

$1 \mathrm{ln} .1 \mathrm{ln} .1 \mathrm{ln}$.

2 in. 2 in. 2 in.

- - -

\subsubsection{Radiological Characterization. The preliminary radiological}

characterization results for tanks $W-13$ and $w-14^{4}$ indicates residual

contents of 1,700 and 4701 , respectively. Tank $W-15$ was not sampled. The total radionuclide inventory in tank $W-13$ was estimated to be about $400 \mathrm{Cl}$, making tank $W-13$ one of the three tanks of those sampled containing the most significant radioactivity. The total radionuclide inventory in tank W-14 was estimated to be about $10 \mathrm{Cl}$. The general beta-gamma background levels fust adove the contents of tanks $W-13$ and $W-14$ is 6.5 and $5.7 \mathrm{rad} / \mathrm{h}$, respectively. Soll contamination in the north tank tarm around tanks $\mathrm{W}-13$, $W-14$ and $W-15$, s most $1 y^{137} \mathrm{Cs}$ and ${ }^{90} \mathrm{Sr}$. Characterization data on these tanks is summarized in Tables $3-5$.

\subsection{Concrete Thorium Waste Tank TH-4}

2.4.1 Location and Adjacent Fac1lities. The TH-4 tank is located about $50 \mathrm{ft}$ from Bullding 3500. There are no other adjacent waste tanks, the nearest waste tanks being approximately $300 \mathrm{ft}$ away. A dry well is adjacent to the tank. 
2.4.2 Tank Construction. This Gunite tank, according to Dwg. A-56869 (which was redrawn from May 29, 1943, drawing) 1s $20 \mathrm{ft}$ in diameter and $9 \mathrm{ft}$ from floor to center of dome. Capacity is approximately 14,000 gai. The side wall is 3-in. thick and the roof is $31 / 2-i n$. Relnforcing steel is $3 / 8$ and $1 / 2 \mathrm{in.} \mathrm{rods.} \mathrm{The} \mathrm{tank} \mathrm{is} \mathrm{covered} \mathrm{with} \mathrm{approximately} 6 \mathrm{ft}$ of sol1 and the bottom of the tank 1s approximately $15 \mathrm{ft}$ below grada. The dry well is fabricated of concrete and is $2 \mathrm{ft}$ square inside and $3 \mathrm{ft}$ square outside. It extends to the surface and is approximately $15 \mathrm{ft}$ deep. Several years ago, a drain from the dry well was damaged and covered with earth approximately $200 \mathrm{ft}$ south.

2.4.3 Tank History and Contents. During the 40 years since the tank was installed, it has received waste from the Irradiated thorlum and uranium p1lot plant development projects in the Bullding 3550 semiworks. The tank 18 filled $w$ alkaline thorlum and urantum sludge.

2.4.4 Tank Access and Sampling. The design construction of tank Th-4 provide for only one $30 \mathrm{in}$. manhole, a $12 \mathrm{ln}$. open pipe in the top and a $4 \mathrm{in}$. vent. These penetrations are surrounded by approximately $6 \mathrm{ft}$ of soll which covers the tank.

2.4.5 Radiological Characterization. The preliminary radiological characterization results for tank $\mathrm{TH}-4$ show the tank contains about 2,000 1 of sediment covered by 37,0001 of water. Radionuclide concentrations found in $\mathrm{TH}-4$ are relatively low; the total activity was estimated to be about $10 \mathrm{mCl}$. The most active radionuclide found was ${ }^{137} \mathrm{Cs}$. A variety of 
heavy radionuclides were also identified, but their activity concentrations were quite low. The beta-gamma background radiation measured just above the tank contents is $8.1 \mathrm{mrad} / \mathrm{h}$. Characterization data on tank $\mathrm{TH}-4$ is summartzed in Tables 3-5.

\subsection{Gunfte Concrete Tank W-11}

2.5.1 Location and Adjacent Facil "ies. Tank $W-11$ is located on the southeast corner of the south tank farm. W-11 is approximately $100 \mathrm{ft}$ north of the east end of Bldg. 3517 and approximately $50 \mathrm{ft}$ from Bldg. 3515. Tank W--12 (which is still in operation) is approximately $15 \mathrm{ft}$ away and has a $3 \mathrm{in.}$. SS overflow Iine into $W-11$. An adjacent valve pit serves both $W-11$ and $W-12$. A second surplus valve pit downstream serves only $\mathrm{W}-11$.

2.5.2 Tank Construction. Tank $W-11$ is the smallest gunite concrete tank, with a volume of $1500 \mathrm{gal}$. The diameter is $8 \mathrm{ft}$ and height $5.5 \mathrm{ft}$ to dome at the center of the tank. The sidewalls are $5 \mathrm{1n}$. thick and the roof and bottom $3 \mathrm{in}$. thick. Reinforcing steel consist of $3 / 8$ and $1 / 2$ in. bars with turnbuckles. The surplus valve pit is $4 \mathrm{ft} \times 5 \mathrm{ft} \times 7 \mathrm{ft}$ deep, constructed of concrete, and extends to surface level.

\subsubsection{Tank History, Use, and Contents. Tank W-11 was constructed} approximately 40 yrs ago. It has been used as a waste collection and monitoring tank from various research laboratorles in B1dg. 3550. The tank was removed from service because of leaks. It is highly contaminated Internally. Present contents are estimated to be $2 \mathrm{ft}$ deep. 
2.5.4 Tank Access and Sampling. Tank $W-11$ has a 30 in. manhole in the top. The entry goes through approximately $6 \mathrm{ft}$ of soll cover over the tank.

\subsubsection{Radiological Characterization. The preliminary radiological} characterization results for tank $w-11^{4}$ show the tank contains about 1701 of sediment covered by 1,0001 of water. Radionuclides found in tank W-11 include ${ }^{137} \mathrm{Cs},{ }^{238} \mathrm{Pu}$, and ${ }^{90} \mathrm{Sr}$, but the total estimated Inventory is less than $1 \mathrm{mCl}$. The beta-gamma background level found above the tank contents is about $40 \mathrm{mrad} / \mathrm{h}$. Radionuclides found in soil samples include ${ }^{137} \mathrm{Cs}$ and ${ }^{90} \mathrm{Sr}$. Characterization data on tank $\mathrm{W}-11$ is summarized in Tables $3-5$.

\subsection{Stainless Steel Thorlum Waste Tanks, TH-1, TH-2, and TH-3}

2.6.1 Location Adjacent Fac1lities. Tanks $\mathrm{TH}-1$, $\mathrm{TH}-2$, and $\mathrm{TH}-3$ are located just south of B1dg. 3503. These tanks are near operating waste tanks WC-5, WC-6, WC-8 and WC-9.

Tank $1 \mathrm{H}-2$ is bordered by $\mathrm{TH}-3$ on the east side and operating waste tank WC-5 on the south side. Tank TH-1 18 approximately $20 \mathrm{ft}$ from WC-9 and $25 \mathrm{ft}$ from tanks $\mathrm{TH}-2$ and WC-5. These tanks are all served by a common pump pit which is currently in use.

2.6.2 Tank Construction. Thorium waste tanks TH-1, TH-2 and TH-3 are subsurface stainless steel vessels with approximately $5 \mathrm{ft}$ of soil cover. Volumes are $2,500,2,400$, and $3,300 \mathrm{gal}$, respectively. Tanks $\mathrm{TH}-1$ and $\mathrm{TH}-2$ were used tanks prior to installation.

Tank TH-1 approximately $7 \mathrm{ft}$ in dia $\times 9.5 \mathrm{ft}$ long, was obtained from the burial ground. It is a single wall dished head tank with metal legs 
mounted on a six in. thick 7 ft $x 7$ ft flat surface concrete pad with $1-1 \mathrm{n}$. U-bolts. No Indication was found that this tank is embedded in concrete. It has approximately $5 \mathrm{ft}$ of soil cover.

Tank $\mathrm{TH}-2$, approximately $7 \mathrm{ft}$ in dia by $10 \mathrm{ft}$ tall and fabricated of 347 SS, was previously steam $\mathrm{j}$ acketed and used in metal recovery, B1dg. 3505. The tank had the steam jacket removed and anchor bolts welded around the tank for anchoring in a concentric facket of concrete up to the bottom of the dished head. A reverse dished head is used on the bottom. The concrete jacket extends under the tank including the cavity under the reverse dished head. Metal legs and $3 / 4 \times 18 \mathrm{in}$. long anchor bolts connects the tank to a $1 \mathrm{ft}$ thick $\times 10.67 \mathrm{ft} \times 20.67 \mathrm{ft}$ concrete pad. A 2 in. $x 4$ in. drainage trough is built into the concrete pad and is accessed by way of a dry well with $8 \mathrm{in}$. VC tile shaft.

Tank $\mathrm{TH}-3,9.17 \mathrm{ft}$ in dia $\times 10 \mathrm{ft}$ tall, is constructed of $1 / 4 \mathrm{in}$. 347SS. The tank with welded construction has flat heads with the bottom having a $2 \mathrm{in}$. slope. The top has two layers of: $1 / 4 \mathrm{in}$. plate. The tank is encircled with a $9 \mathrm{in}$. thick relnforced ( $1 / 2$ in. steel) concrete jacket held to the tank with $1 / 2$ in. steel anchor rods. The concrete jacket covers the top of the tank with an $11 \mathrm{in}$. layer. The concrete cover is supported by approximately 28 linear ft of $5.4 \mathrm{lb} / \mathrm{ft} 4 \mathrm{in}$. channel.

\subsubsection{Tank History, Use, and Contents. Installation details were} prepared in 1948 for TH-1 and in 1952 for tanks TH-2 and TH-3. All of these tanks recelved waste from the thorium pilot plant project located in Bldg. 3503. 
2.6.4 Tank Access and Sampling. Tank TH-1 has thirteen nozzles in the cover located on a $2.5 \mathrm{ft}$ radius about the center of the tank plus one additional small nozzle and a manhole with a $2 \mathrm{ft} 1 \mathrm{ln}$. cover plate. Access to the tank is olily through the service pipes provided including a $1 / 2$ in. sample return line, $1 / 2 \mathrm{ln}$. sample 1 ine, $1 / 2 \mathrm{in}$. 1iquid level line, $1 / 2$ in. specific gravity 1 ine, $1 / 2 \mathrm{ln}$. alr sparger line, a $1 \mathrm{ln}$. total draw line, $1 \mathrm{in}$. filler pipe and $2 \mathrm{in}$. inlet pipe from thorium drain from Bldg. 3503.

Tank $\mathrm{CH}-2$ has nine nozzles spaced around a circumference on the head of the tank plus a manhole at the center. The manhole is apparently a standard $18 \mathrm{in}$. size. Access to the manhole is by the hatch and a $2 \mathrm{in}$. suction line, 2 in. sparger 1 ine, and two $1 / 2$ in. sample 1 ines and a 2 in. gravity fill line from Bldg. 3503.

Tank TH-3 has nine nozzles spaced around a circumference on the tank head plus a manhole at the center. The manhole is apparently a standard 18 1n. size. Access to the tank is by the hatch, two $1 / 2$ in. sample 11nes, a 2 in. sparger line, 2 in. suction line and 2 in. gravity drain line from B1dg. 35 J3.

\subsubsection{Radiological Characterization. The preliminary radiological} characterization results for tanks $\mathrm{TH}-1$ and $\mathrm{TH}-3^{4}$ indicates residual contents of 1,8001 and 2,6001 , respectively. Tank $T H-2$ was not sampled because of high radiation levels. The direct beta-gamma dose measured over shielding covering the access to TH-2 was $150 \mathrm{mr}$ ad/h. This dose Increased to $6 \mathrm{rad} / \mathrm{h}$ when the shielding was removed. Raddonuclide inventories in tank TH-2 may exceed those in any of the tanks which were sampled. Radionuclide inventories in tanks $\mathrm{TH}-1$ and $\mathrm{TH}-3$ were estimated to be less 
than $1 \mathrm{Cl}$ each, consisting mostly of $137 \mathrm{Cs}, 90 \mathrm{Sr}$ and ${ }^{60} \mathrm{Co}$. Beta-gamma radiation levels above the contents of tanks $\mathrm{TH}-1$ and $\mathrm{TH}-3$ are 53 and $9 \mathrm{mrad} / \mathrm{h}$, respectively. Soll contamination at the site consists mainly of ${ }^{137} \mathrm{Cs}$ and ${ }^{90} \mathrm{Sr}$. Characterization results on tanks $\mathrm{TH}-1, \mathrm{TH}-2$ and $\mathrm{TH}-3$ are sumarized in Tables 3-5.

\subsection{Isotope Area Stainless Steel Tank WC-1}

2.7.1 Location and Adjacent Facilities. Tank WC-1 is a subsurface stainless steel tank located just east of Bldg. 3038 and west of B1dg. 3037 in the approximate center of the OKNL facilities at the X-10 site. An abandoned valve pit is located on the west side of the tank.

2.7.2 Tank Construction. Tank WC-1 is a 2,000 gal tank made of stainless steel. It has a flat top reinforced by external ribs. The tank has a diameter of $8.66 \mathrm{ft}$ and has a sloping bottom with the height being $5.75 \mathrm{ft}$ on the shallow side and $6 \mathrm{ft}$ on the deep side. It is mounted to a sloping octagonal concrete pad $9.5 \mathrm{ft}$ across the flats with four equally spaced anchor bolts $3 / 4 \mathrm{in} . \times 6 \mathrm{in}$. 1ong. The pad is $6 \mathrm{in}$. thick on the thin side and $9 \mathrm{in}$. on the thick side. The pad has $3 / 8 \mathrm{in}$. steel reinforcement rods $12 \mathrm{in}$. apart in both directions with layers at both top and bottom. Gravel backfill extends around the pad a minimum width of 18 in. A dry well with a 6 in. VC tile extending from the bottom edge of the pad to the surface is located next to the low side of the pad. The tank initially was covered with approximately $10 \mathrm{ft}$ of soll.

An associated valve pit is located on the west side of the tank. The abandoned valve pit is constructed of reinforced concrete. It is $8.25 \mathrm{ft} x$ 
5 ft $\times 7$ ft deep and has a 6 in. thick concrete cover. The pit has been entombed by filling with concrete.

2.7.3 Tank History, Use, and Contents. Tank WC-1 has been used for collection and monttoring of process liquid waste from lsotope production and development laboratories in B1dgs. 3038, 3028, 3029, 3030, 3031, 3032, 3033, 3047, f11ter Bldg. 3110, stack 3039, and scrubber 3092. The tank was abandoned in 1968 because of leaking discharge line. The tank contains curle quantities of ${ }^{60} \mathrm{Co},{ }^{137} \mathrm{Cs}$, and ${ }^{90} \mathrm{Sr}$ residual contamination.

\subsubsection{Tank Access and Sampling. Tank access is by ten lines which} provide tank services. Two $2 \mathrm{in}$. suction 1 ines run from the ejector pit through nozzles in the tank top and terminate at a tack-weld onto the bottom of the tank. A $1 / 2$ in. Ine runs to the sampling station along with a $1 / 2 \mathrm{ln}$. return drain line. Lines running from the tank to the ejector pit includes, a $1 / 2$ in. sparger line, $1 / 2$ in. short leg specific gravity line, $1 / 2 \mathrm{ln}$. long leg-spectfic gravity line, $1 / 2 \mathrm{ln}$. liquid level line and $1 / 2 \mathrm{1n}$. Datum line. Originally the tank was filled by a 6-in. waste drain which also vented the tank to the stack. A 3-in. stainless steel line now connects this tank to WC-10.

2.7.5 Radiological Characterization. Tank WC-1 was not surveyed as part of the preliminary radiological characterization as all access to the tank was eliminated when the valve pit was entombed. Previous reports suggest curie quantities of ${ }^{60} \mathrm{Co},{ }^{137} \mathrm{Cs}$ and ${ }^{90} \mathrm{Sr}$ may be present. Soll samples taken at the WC-1 site were contaminated with ${ }^{60} \mathrm{Co},{ }^{137} \mathrm{Cs}$, and $90 \mathrm{Sr} .4$ 


\subsection{Butlding 4500 Area Stainless Stee1 Tanks WC-15 and WC-17}

2.8 .1 Location and Adfacent Facil1t1es. Tanks WC- 15 and WC-17 are subsurface stalnless steel tanks located fust south of Bldg. 3587 and west of B1dg. 4508. These tanks are located just inside the north-west quadrant formed by the intersection of Fifth Street and White Oak Avenue.

Tanks $W C-15$ and $W C-17$ are on the north end of a row of fIve Identical tanks Installed on the east side of a common pad. The other three tanks in this row, $W C-12, W C-13$ and $W C-14$, are sti11 in service as are two horizontally mounted tanks WC-10 and WC-11 positioned on the west side of the pad. A partially submerged concrete vault pump pit which serves all of these tanks is located on the west side of this tank cluster.

\subsubsection{Tank Construction. Tanks $W C-15$ and $W C-17$ are constructed of} 1/4 in. 347 stainless steel. They are 1,000 gal, vertically orlented dished head vessels $5 \mathrm{ft}$ in dia by $6.5 \mathrm{ft}$ tall. Each tank is mounted with four welded legs to the sides of the tanks made of $3 \times 3 \times 3 / 8$ in. steel angle with $41 / 2 \times 41 / 2 \times 1 / 4$ in. feet plates. The tanks are anchored to the common pad with $3 / 4 \mathrm{in}$. anchor bolts. The concrete pad which serves the two defective tanks and five operating tanks has a ralsed curb around the perimeter. The pad reinforced with $6 \times 12 \mathrm{in}$. mesh 33 wire both ways has dimensions of $16.75 \times 34 \times 1 \mathrm{ft}$ with the thickness at the curb being $1.5 \mathrm{ft}$. A dry well sump 1s located west of WC-10. The dry wel1 $1 \mathrm{~s}$ accessed by a 24-in. concrete pipe which extends from the pad to the surface. After installation the tanks were backfilled with soil and gravel which has the appearance of local shale-type soll to a cover depth of approximately $10 \mathrm{ft}$. 


\subsubsection{Tank History, Use, and Contents. Tanks WC-15 and WC-17} collected waste from varlous research laboratories in B1dg. 4500 . They were removed from service because of leaks.

\subsubsection{Tank Access and Sampling. Access to tanks WC-15 and WC-17 1s} by way of the service piping. Each tank had a $16 \mathrm{in}$. manhole in the center of the head through which a float gauge was mounted. However, the opening on WC-15 no longer reaches to grade level. The float gauge line is a $2 \mathrm{In}$. pipe which is now capped. Tank nozzles for other piping are located around a clrcumference on the tank head. An Inlet fill line comes to each tank from the Bldg. 4500 area. Other service lines make connection with the pump pit including a $1 / 2 \mathrm{ln}$. sample drawoff 1 ine and $1 / 2 \mathrm{ln}$. sample retum IIne, two $2 \mathrm{in}$. spare 1 ines to the pump pit and a line connecting the header to tanks WC-10 and WC-11. These tanks presently have no readily accessible opening.

\subsubsection{Radiological Characterization. The preliminary radiological} characterization showed that tank WC-17 contalns about 15001 of 011 and 36001 of water. ${ }^{4}$ Tank WC-15 was not sampled as no surface connections remain. The total radionuclide inventory is 1 ess than $10 \mathrm{mCl}$, and consists of a variety of transuranice, ${ }^{90} \mathrm{Sr}$, and ${ }^{137} \mathrm{Cs}$. The radiation level above the tank contents is about $0.15 \mathrm{mrad} / \mathrm{h}$. Soll cores taken in the vicinity of tanks WC-15 and WC-17 are contaminated over their full length w1th no predominant distribution patterm. Radionuclides observed in the soll include ${ }^{137} \mathrm{Cs},{ }^{90} \mathrm{Sr},{ }^{60} \mathrm{Co},{ }^{241} \mathrm{Am}$ and ${ }^{244} \mathrm{Cm}$. The history of this site suggests previous problems with tank leakage. Results of the radiological characterization are summarized in Tables 3-5. 


\subsection{DECOMMISSIONING ALTERNATIVES ASSESSMENT}

Several of these surplus tanks leak. Others are slngle-wall concrete tanks. These tanks have essentially no lmmediate or long-term reuse potential. Therefore, they need to be decontaminated and decommissioned.

The ad hoc review committee considered the variable alternatives. Excerpts

from the minutes of their meeting sumarize the alternatives as follows.

"The discussion of alternatives for the LLW waste tanks centered around the two basic options of in situ entombmerit and complete removal. Long-term reuse of the tanks was rejected due to the presence of leaks in may of the tanks and the outdated containment, transfer and monitoring designs. In general, the concensus of the cormittee was that of the two alternatives only the removal option provided any real long-term solution to the abandoned tanks. Entombment of the tanks would only result in an increase in the number of "radioactive waste disposal sites" at ORNL and would permanently tie up potentlally valuable areas within the main ORNL complex. Furthermore, entombment of the waste tanks would not solve the soll contamination problems that are associated with many of the abandoned tank farms. The discussions on removal alternatives for the tanks then was concentrated on the feasibility of one-plece removal of the tanks, particularly with the larger gunite tanks. It was felt that all of the stalnless steel tanks could be removed without much problem, and that the smaller gunite tanks (8-ft diameter) could perhaps also be handled in one piece. However, for the larger gunite tanks (25- and 50-ft dlameter) some type of segmenting would likely be required.

Prior to removal of any of the tanks, the residual materials inside the tanks (11quids and sludges) would have to be removed. Although most of the tanks have been 1solated from the rest of the tank farm system, it was felt that the removal could be accomplished without great difficulty through new tie-ins to the active LLW system at appropriate points. All the residual materials would be transferred to the LiW processing facilities for treatment prior to final disposal via hydrofracture. Additional decontamination of the interior of the tanks would be accomplished by chemical washing or scarification techniques, as appropriate.

In addition to removal of the waste tanks, all associated facilities (pump pits, valve stations, ingtrumentation, etc.) and contaminated soil would also have to be disposed of. The results of the radiological characterizations of the tank sites can be used to estimate the extent of the soll contamination at most 
sites. In some instances only that soll Imedlately around the tanks would require disposal, while in other instances

(particularly the north tank farm) the sol1 throughout the tank farm would have to be considered contaminated and dealt with accordingly. In the process of removing the ancillary factlities at the tanks, the transfer 11 nes into and away from the sites w1ll have to be removed to the nearest tie-1n to the system or at a well defined boundary of the alte. Each tank farm would have to be analyzed separately to determine the most appropriate point at which to cap the lines.

Based on the compittee declsions and deliturations, the following outline for decommissioning of the tanks should therefore be utilized for the englneering study and estimate: (1) conduct necessary additional characterizations of the tank sites to allow detalled engineering, (2) perform necessary design studies to prepare for decommissioning activities, (3) perform removal tasks for the residual materials in the tanks, (4) conduct any requtred decontamination of the tank interiors, (5) remove tanks eitl. $:$ by one plece lift or controlled segmenting, (6) remove contaminated soll from the site to levels that are consistent with ORNL guidelines for controlled areas, and (7) restore the site to a natural condition. Due to the magnitude of these removal tasks, this work should be costed as a kust* construction fob for all major new construction and tank removal tasks. UCC-ND forces should be utilized for tank clean-out operations, as appropriate."

* On-site construction contractor. 


\subsection{DESCRIPTION OF DECOMMISSIONING PLAN}

The elght groups of waste tanks considered in this report are addressed as separate profects except for some common equipment such as work platforms and assoclated 1tems 11ke pumps, controls, cutting and scarification equipment. The general approach to each group of tanks w111 begin by emptying, rinsing and decontaminating the tank interiors, if necessary. The metal tanks will then be excavated and removed intact. The larger concrete tanks w1ll be segmented into smaller pleces before removal. The operations are summarized below:

The first task w1ll be to complete a radiological characterization study to verify decommissioning requirements. Next, access will be provided to the tanks if needed, usually by setting a platform over the tank for use in mounting access drilling equipment and, finally, pumping and scarification equipment. Such a platform is shown In Fig. 4.

If the tanks have no leaks, the contents of the tanks will be removed followed by washing of the walls remotely with robotic equipment as 11lustrated in Figs. 4 and 5. If the tanks leak, surrounding sol1 w111 be excavated and the leaks located and repalred if posstble. If the leaks cannot be repaired, sumps w111 be bulld under the edge of the tank pad at the leak site to catch any leakage. following remote cleaning, hands-on cleaning using "C" zone clothing may be used, particularly with tanks that are to be segmented before removal and burial.

The metal tanks in most cases w111 be lifted out intact after remote cleaning without hands-on cleaning and segmenting. For the larger gunite 


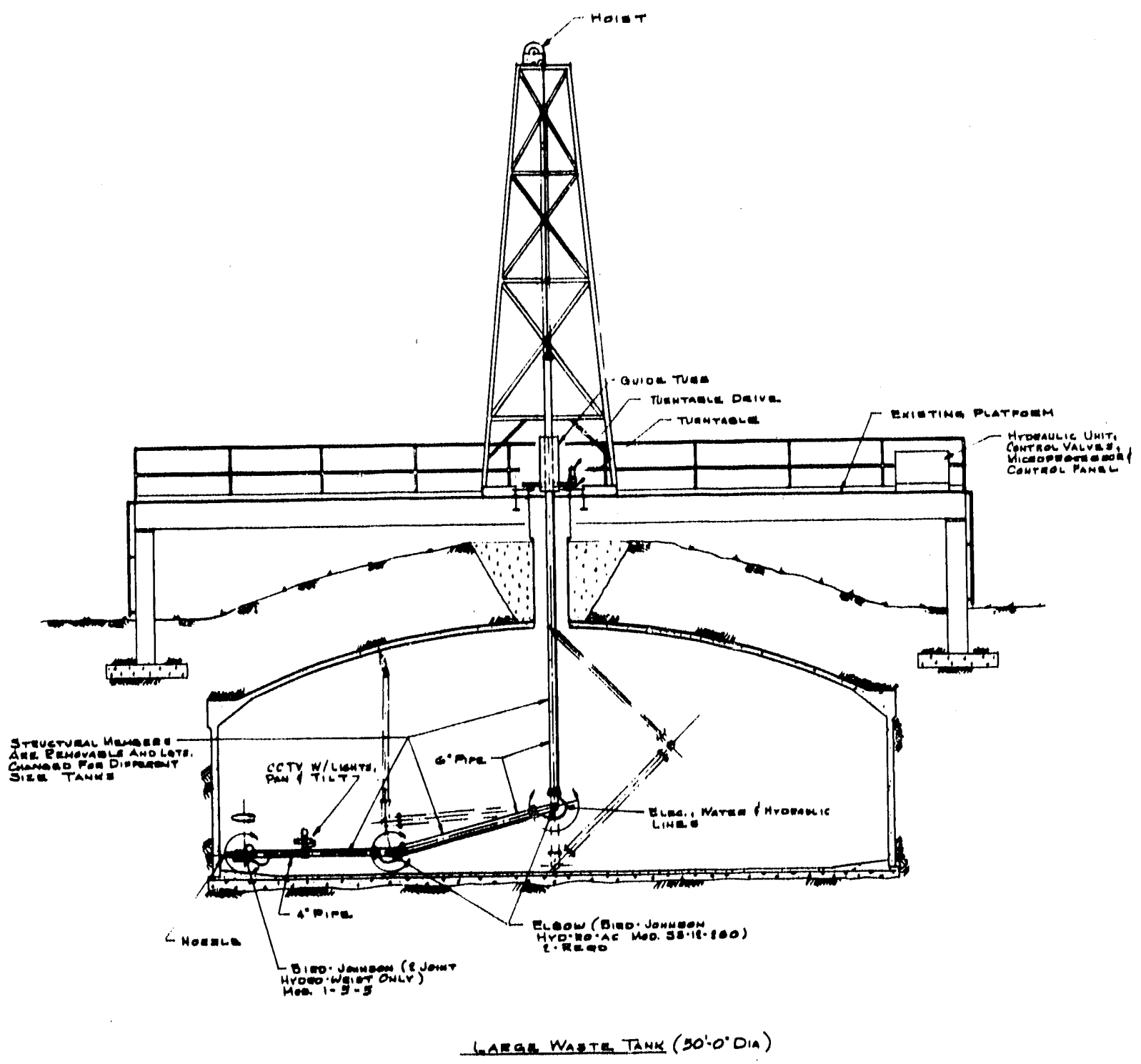

Fig. 4. Work platform and robot arm (shown on large Gunite tank). 


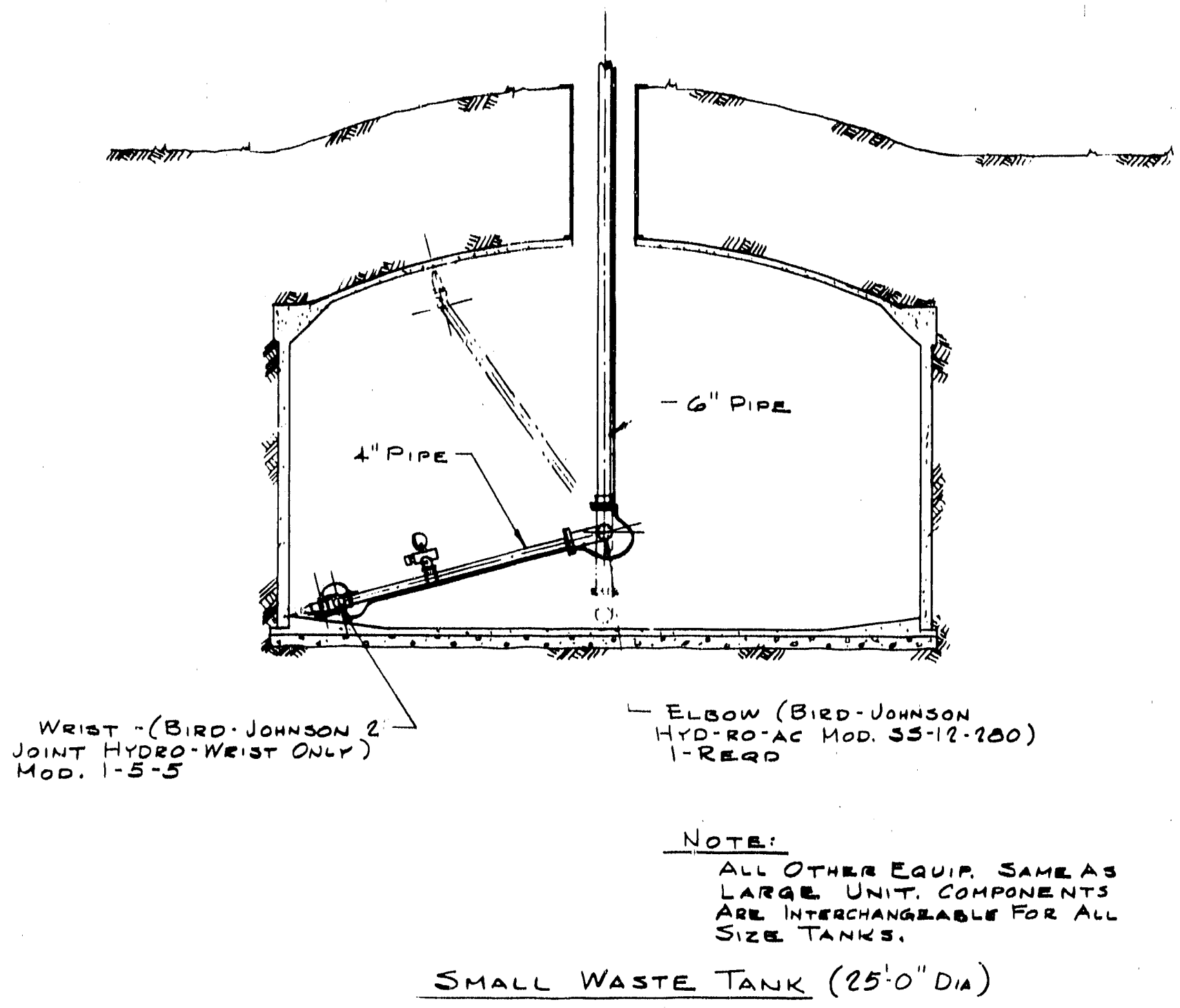

Fig. 5. Robot arm shown on small concrete tank. 
tanks, segmenting will be requixed. The estimates were prepared based on using abrasive fet cutting as the primary cutting technique.

After removing the tanks, any contaminated soll w111 be removed and taken to the burlal ground in dump trucks equipped with plastic liners and zuvers. Transportation and burlal of the tanks and contaminated soll 1s a major task involving up to $10,000 \mathrm{~m}^{3}$ of solid low level radioactive waste. About $94 \%$ of this waste 18 contaminated so11; the rest is the tank material, general rubble, and miscellaneous wastes such as shoe covers, etc. About twice this amount of 8011 will be moved and replaced in the process of uncovering the tanks. These excavations, burlal at the waste disposal site, and backfilling operations cover a major part of the decommissioning effort.

The general approach to the decommissioning of these elght groups of tanks will be:

1. prepare a project plan, support documentation, and radiological characterization;

2. perform detall design and finalize decomissioning procedures; and

3. Implement decomisstoning operations.

Spectfic activities for Individual tanks are found in the cost estimate work sheets in Appendix I. 


\subsection{COST ESTIMATE AND SCHEDULE}

The total cost for decommissioning the eight groups of tanks addressed in this report is $\$ 8,519,000$ in FY-85, first quarter dollars. The cost by group is shown in Table 6 .

Table 6. Lecommissioning Cost of Individual Groups of Tanks

\begin{tabular}{lr}
\hline & \multicolumn{1}{c}{$\$$} \\
\hline North Tank Farm & $1,825,000$ \\
Concrete Tanks W-1 and W-2 & $2,375,000$ \\
Concrete Tanks W-3 and W-4 & $1,901,000$ \\
Stainless Steel Tanks W-13, W-14, and W-15 & $3,101,000$ \\
Subtotal (North Tank Farm) & 407,000 \\
Concrete Tank W-11 & 389,000 \\
Concrete Tank TH-4 & 291,000 \\
Stainless Steel Tanks T-1, TH-2, and TH-3 & 321,000 \\
Stainless Steel Tank WC-1 & 621,000 \\
Stainless Steel Tanks WC-15 and WC-17 & \\
Special Equipment (Common to all of above) & \\
\hline
\end{tabular}

The total cost for each group of tanks would ! e higher than shown in Table 6 after adding the cost of a proportional amount of the $\$ 621,000$ for special equipment which is usable with each group of tanks (including the 
large gunite tanks). If only one group of tanks were involved, that group would encounter all of the special equipment cost. The expenditures by flscal year is provided In Fig. 6. The largest capital equipment costs precede tank removul. Equipment is used at all the sites. The cost estimate work sheets are provided in Appendix I.

The schedule for decommissioning the eight groups of tanks is provided in Fig. 6. The first year involves characterization studies and assessments. Project planning including engineering and equipment development follows, spread out over years two to flve. Actual decommissioning operations are scheduled for years four through seven. Decommissioning of three groups of tanks in the north tank farm are scheduled for years four and five, three groups for year six, and two groups for year seven. The schedule could be shortened considerably under an accelerated program, if necessary. 


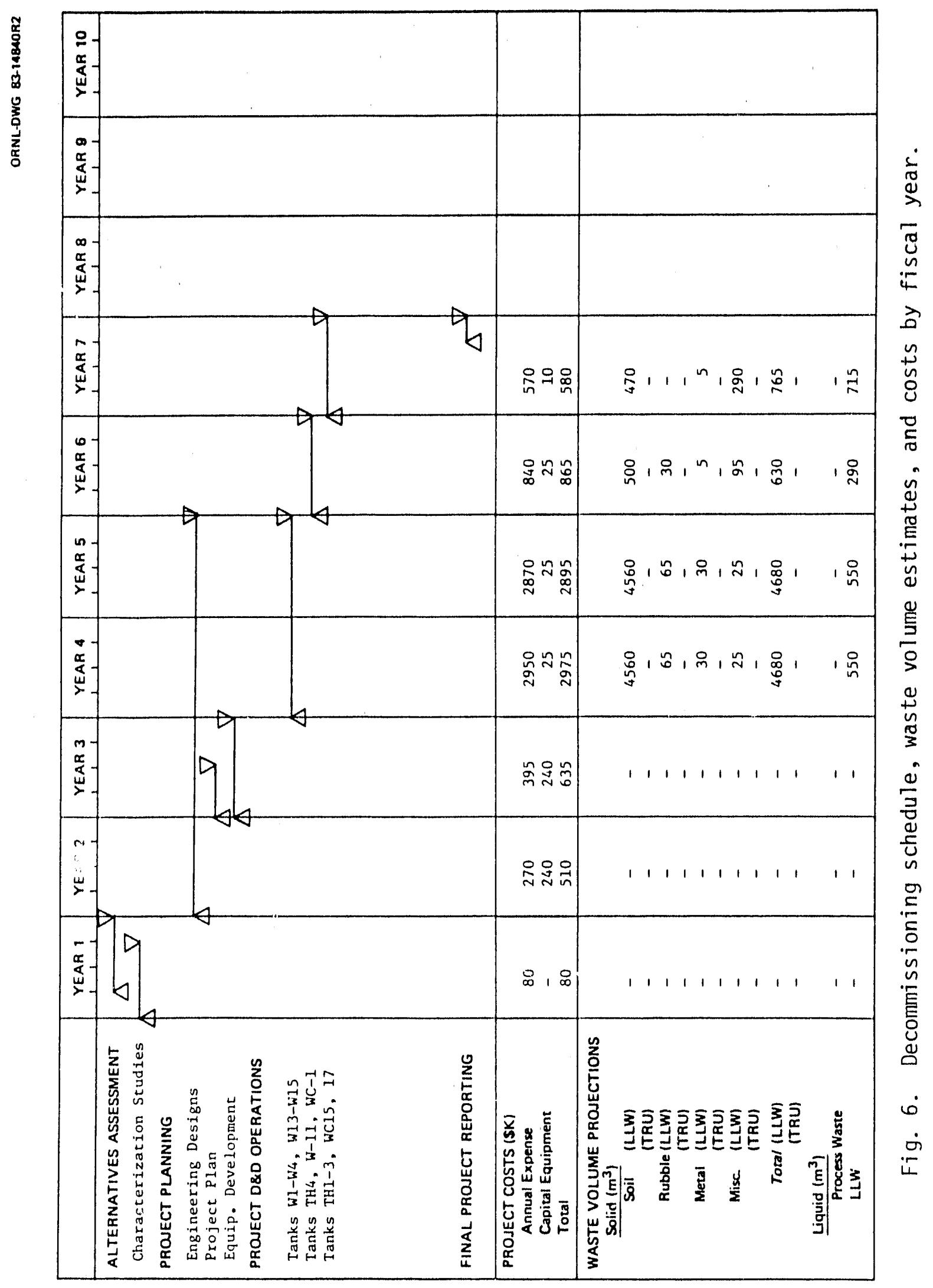




\subsection{REFERENCES}

1. J. R. Horton, Preliminary Decommissioning Study Reports, Volume 4: Gunite Storage Tanks, X-OF-231, Vol. 4, September 1984 .

2. J. A. Cox, E. D. Witkoswk1, L. C. Lasher, Operating Procedures for Radioactive Liquid and Gaseous Waste Disposal, ORNL-CF-64-11-62, June 1971, p.1-8.

3. F. N. Browder, Description and Operation of the Liquid Waste Collection and Monitoring Systems for Bullding 3019, ORNL-CF-54-10-87, p. 6 .

4. S. F. Huang, W. A. Yexander, J. B. Watson, T. W. Oakes, Preliminary Radiological Characterization of the LLW Colletion Tanks, ORNL/CF-84/203, September 1984.

5. G. S. Sadowski, Operating Instructions for Tanks $W-13, W-14$ and $W-15$ in the North Tank Farm Area, ORNL CF 50-3-39, May 1958, p. 1-5.

6. R. D. Ehrlich and H. D. MacNary, et al, Conceptual Design Report for Gunite Tank Sludge Removal, X-OE-73, June 1979.

7. Personal Communication, D. P. Kuban of the Martin Marletta Energy Systems E'ngineering Division, to J. R. Horton, April 1984. 
APPENDIX I

COST ESTIMATE SHEETS 


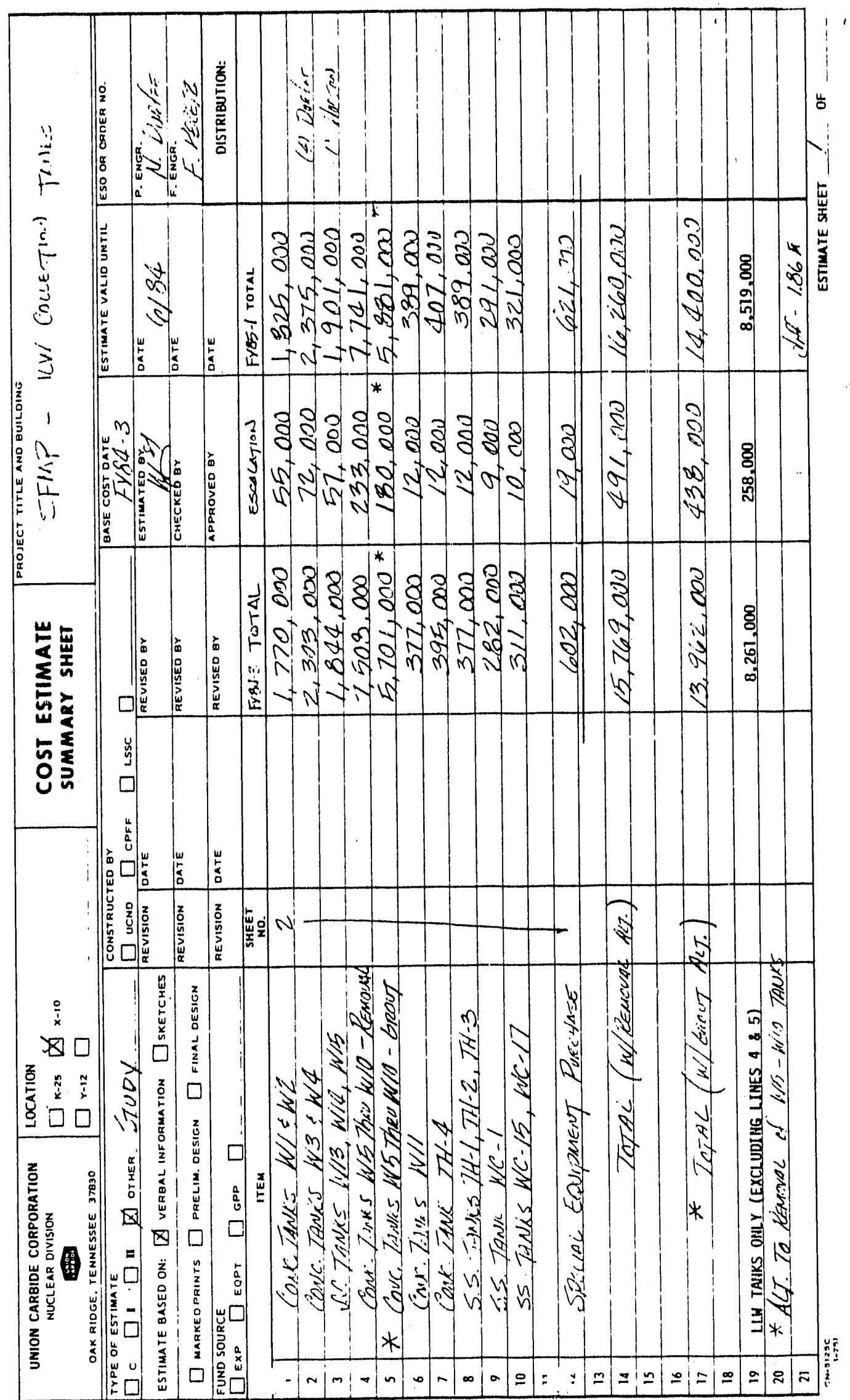




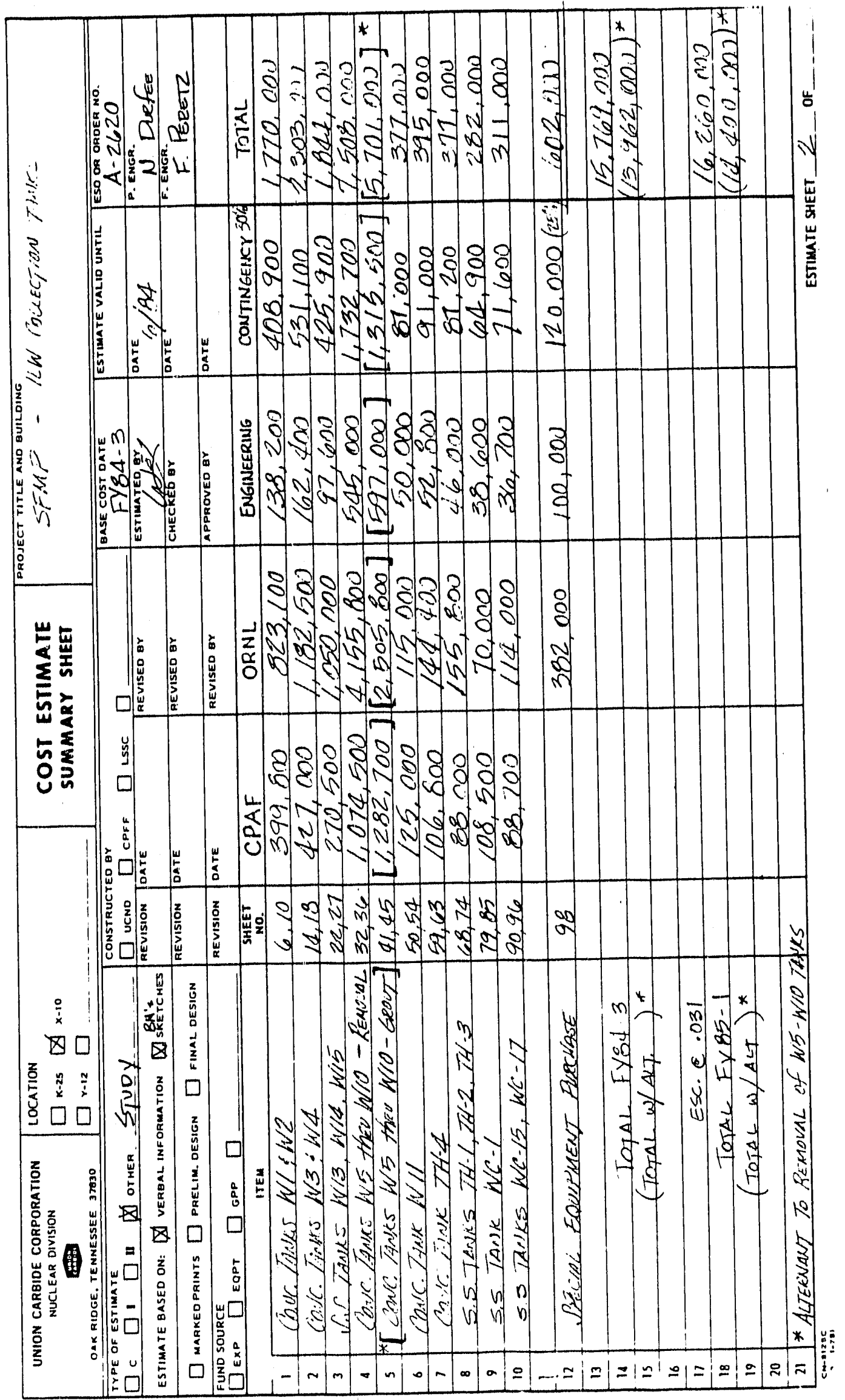




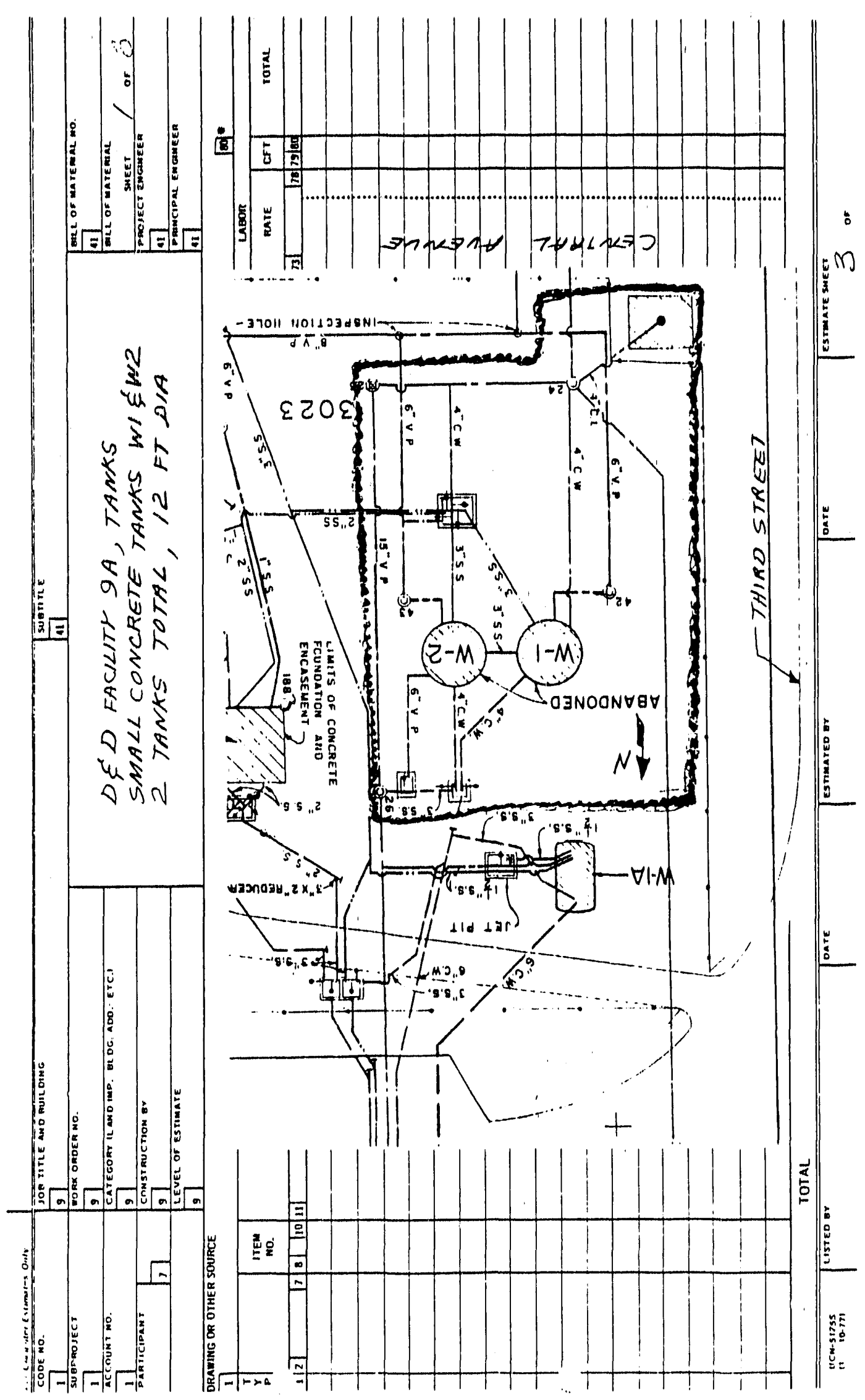




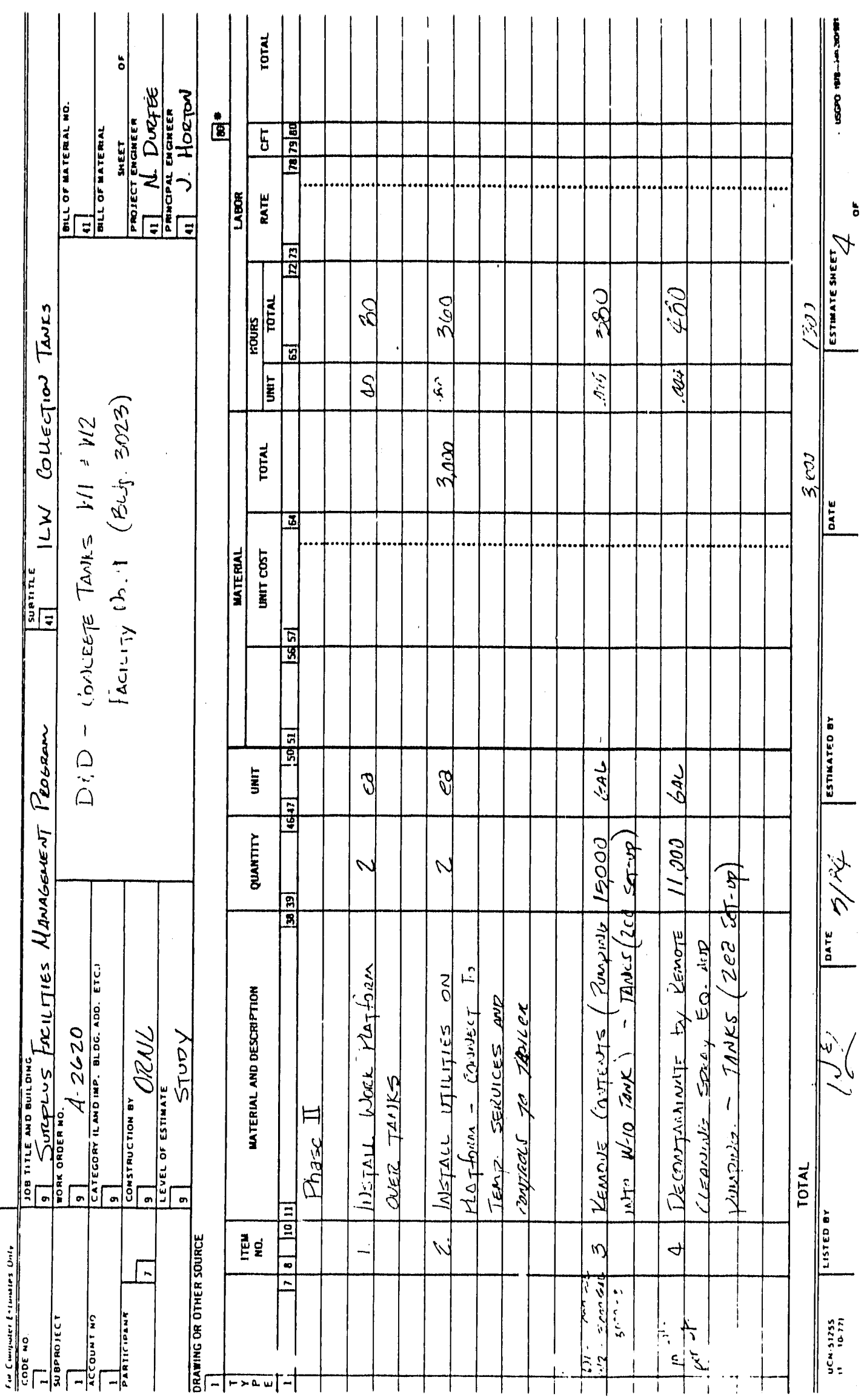




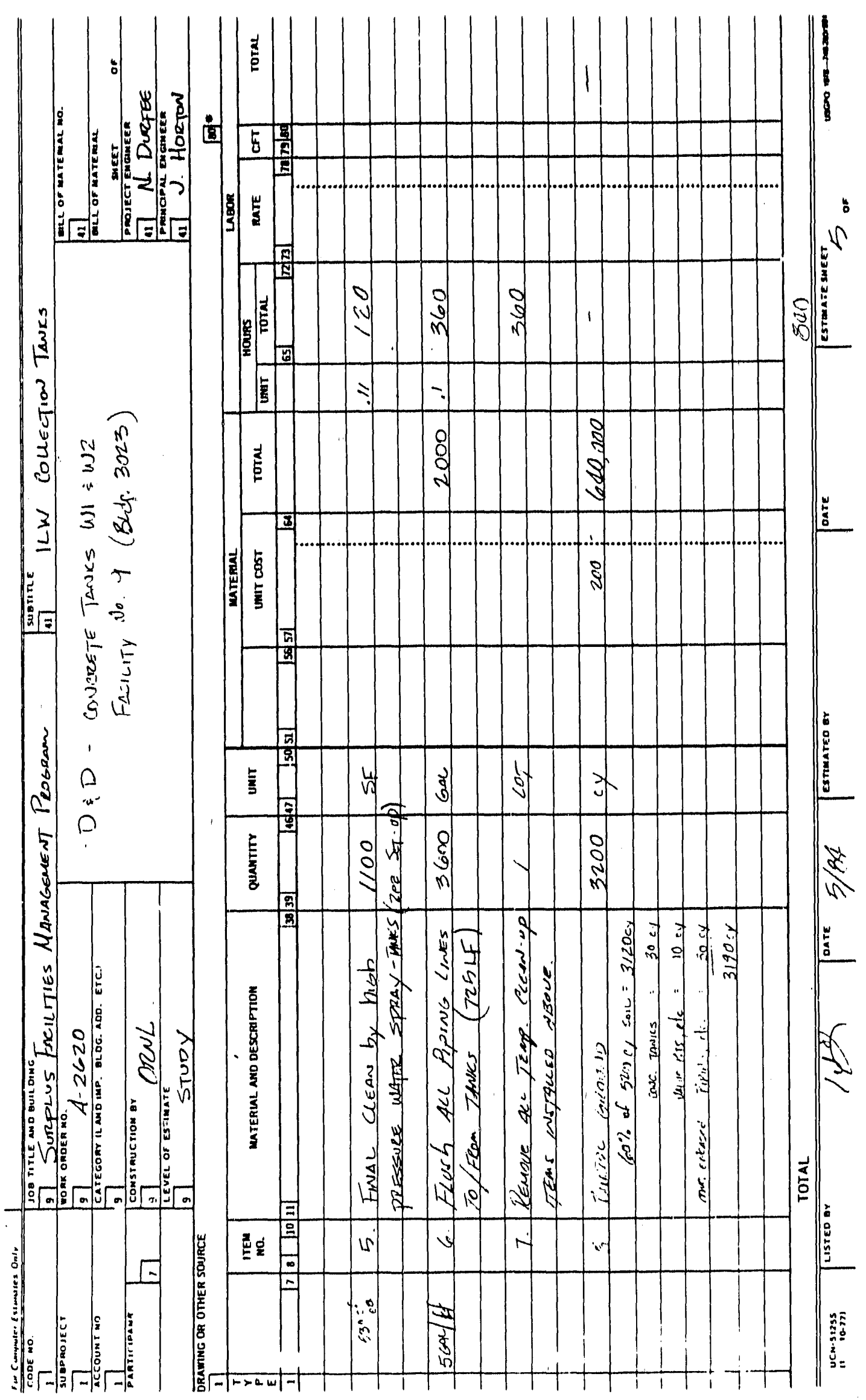




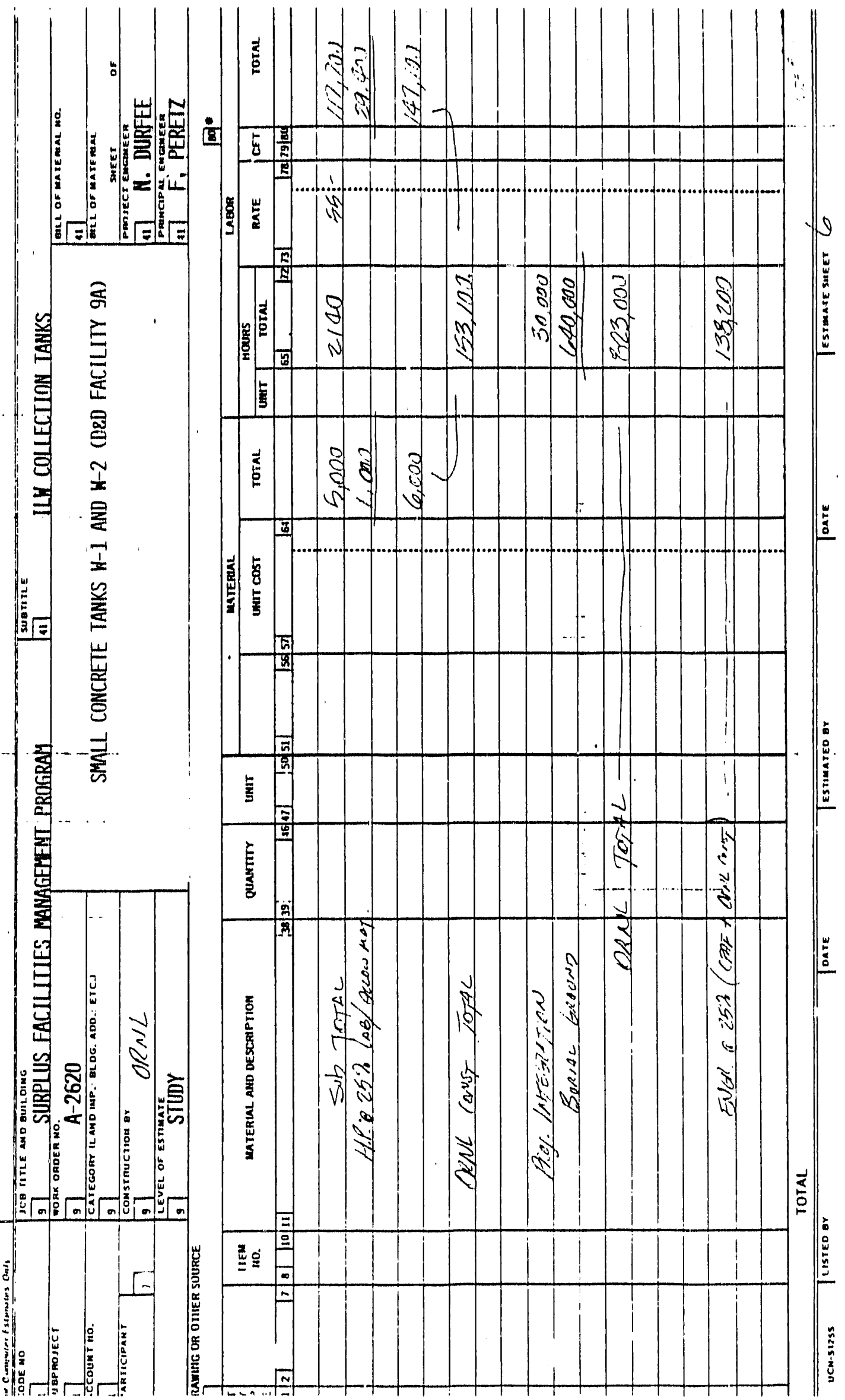




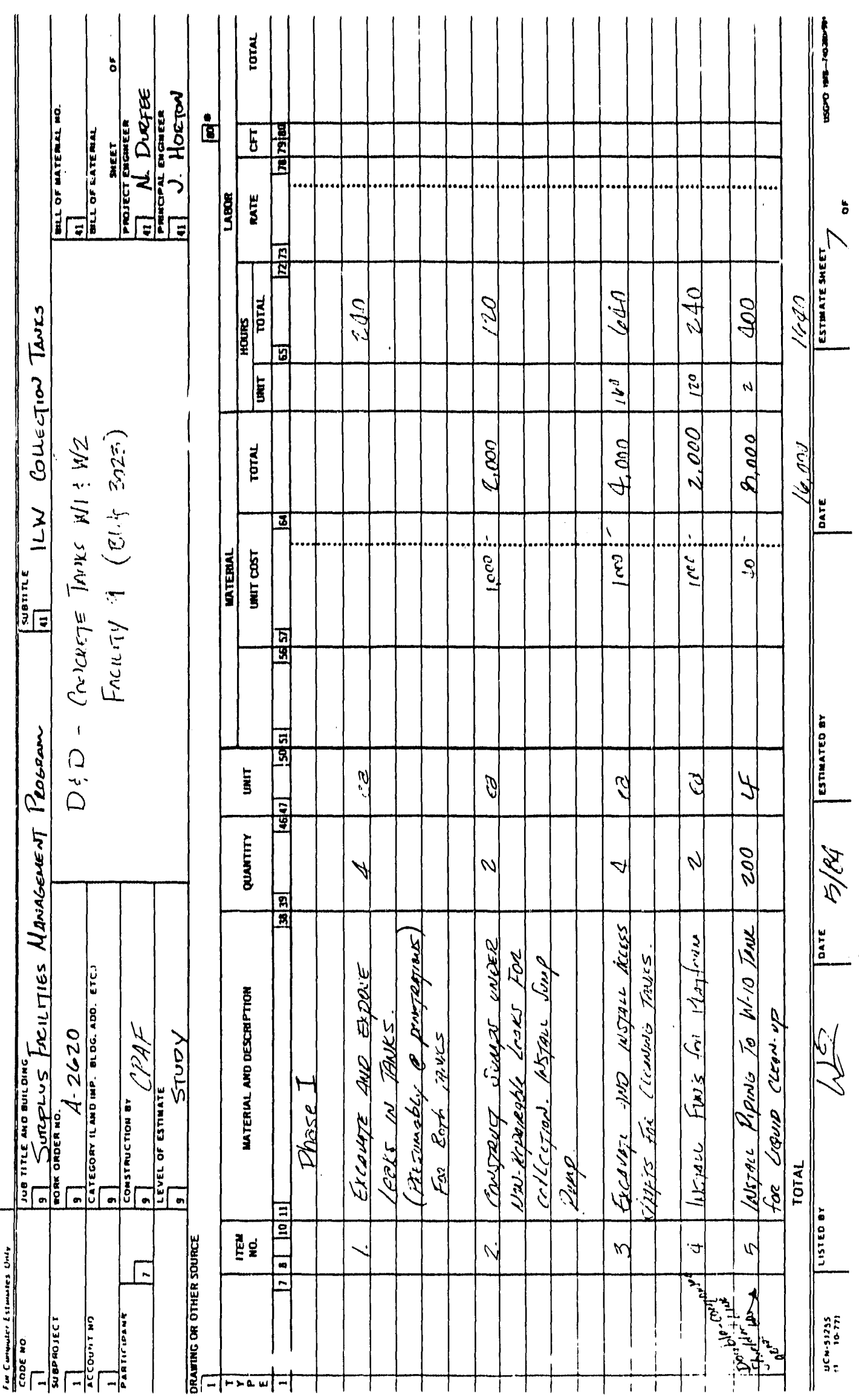




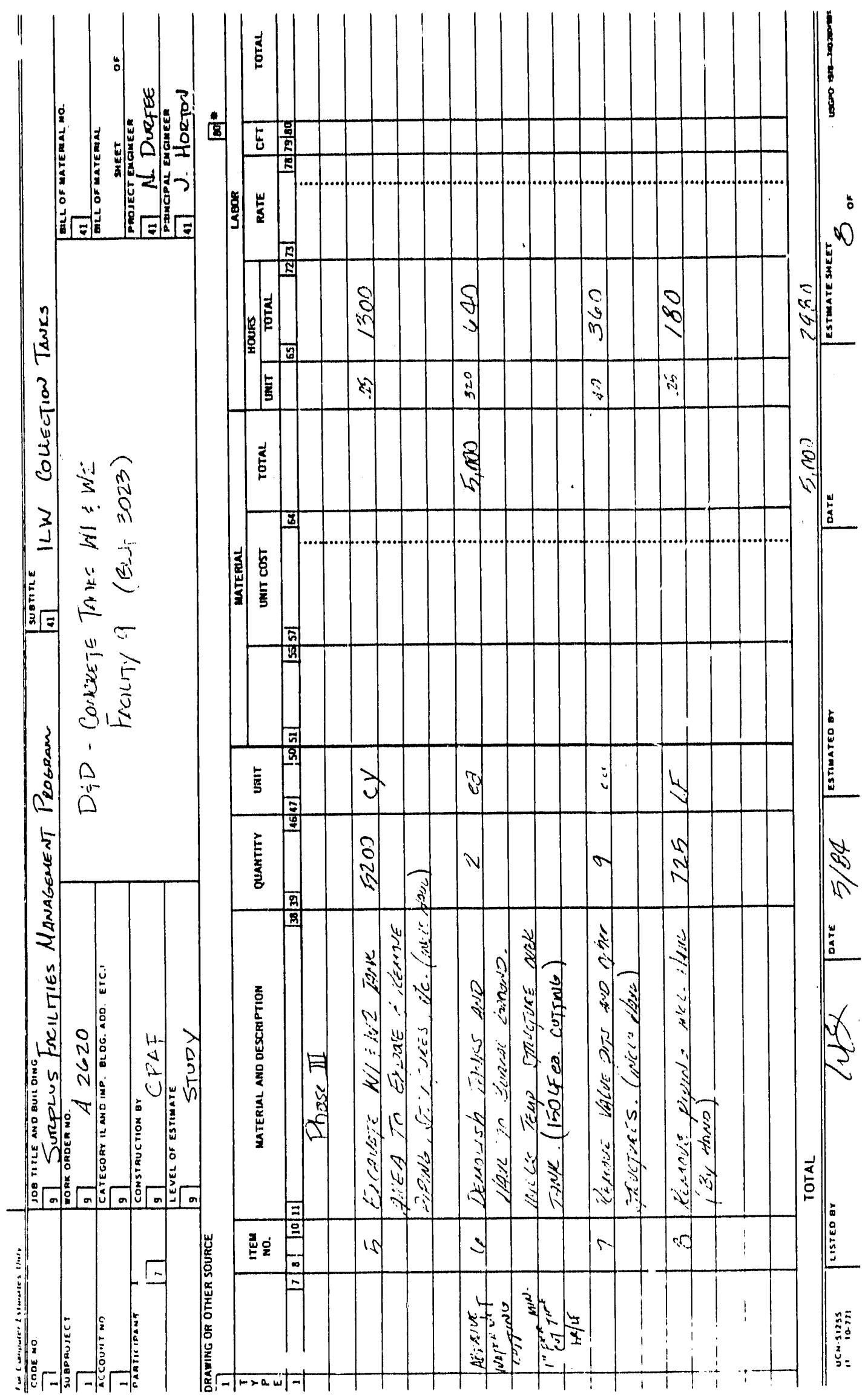


51

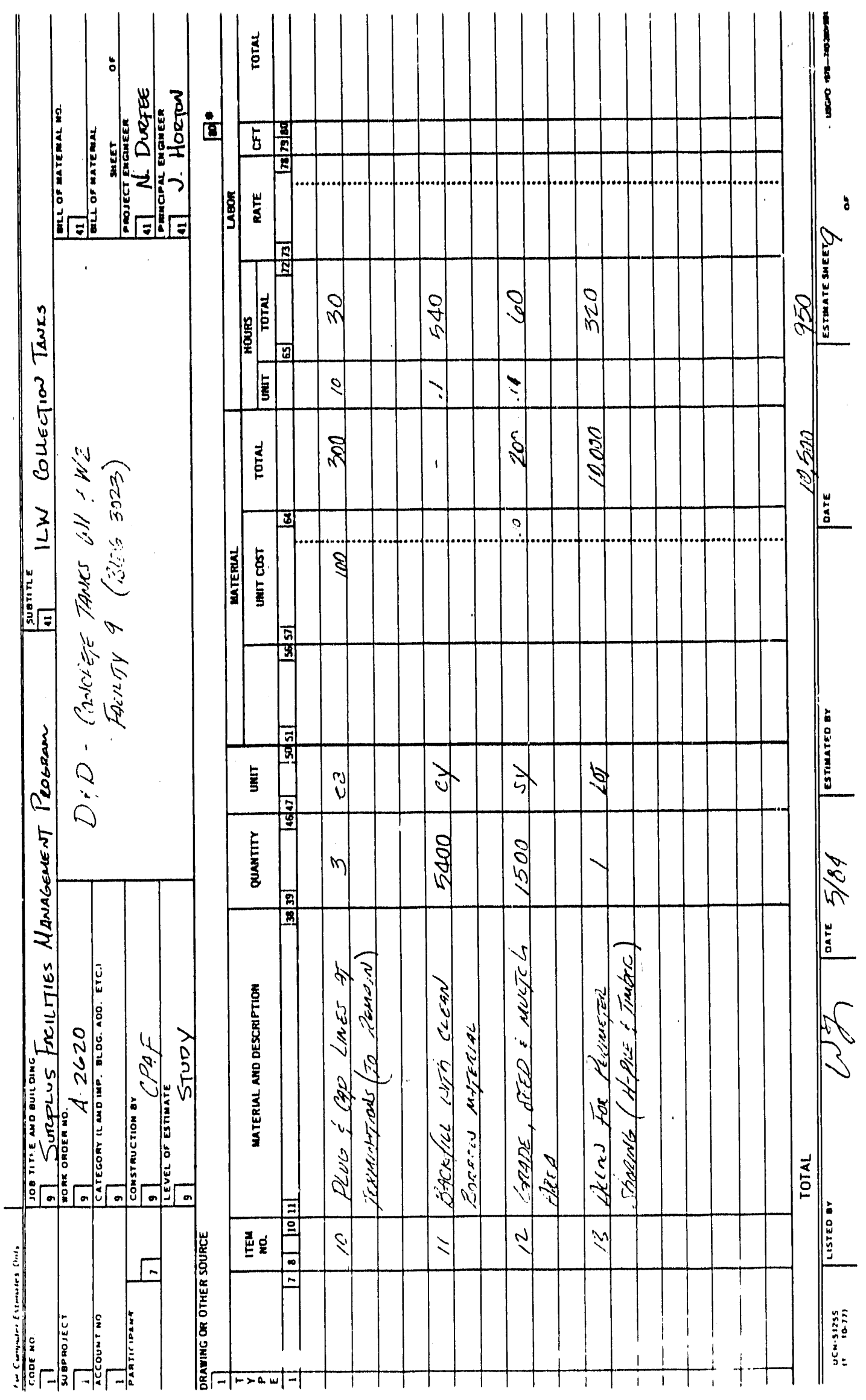




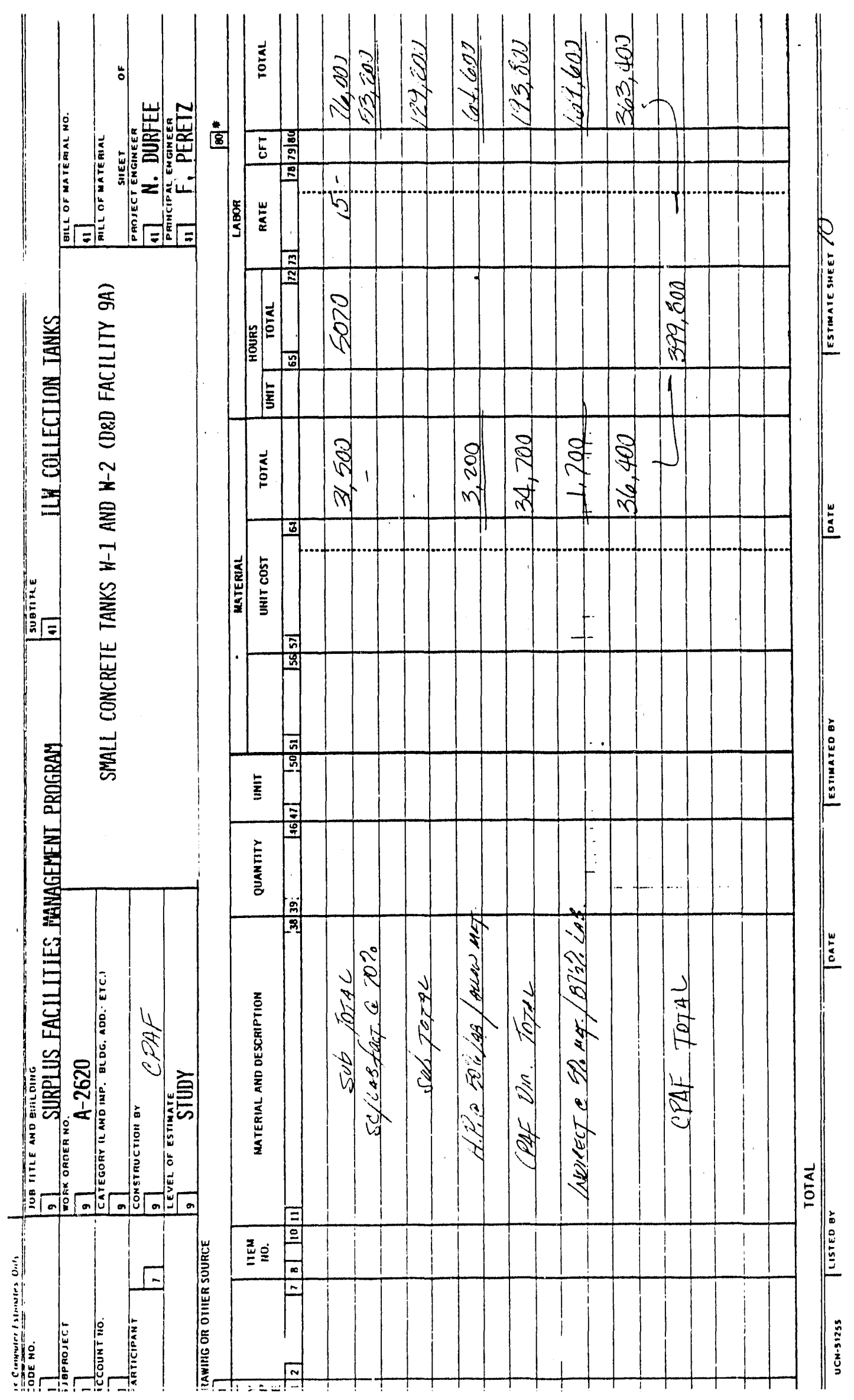




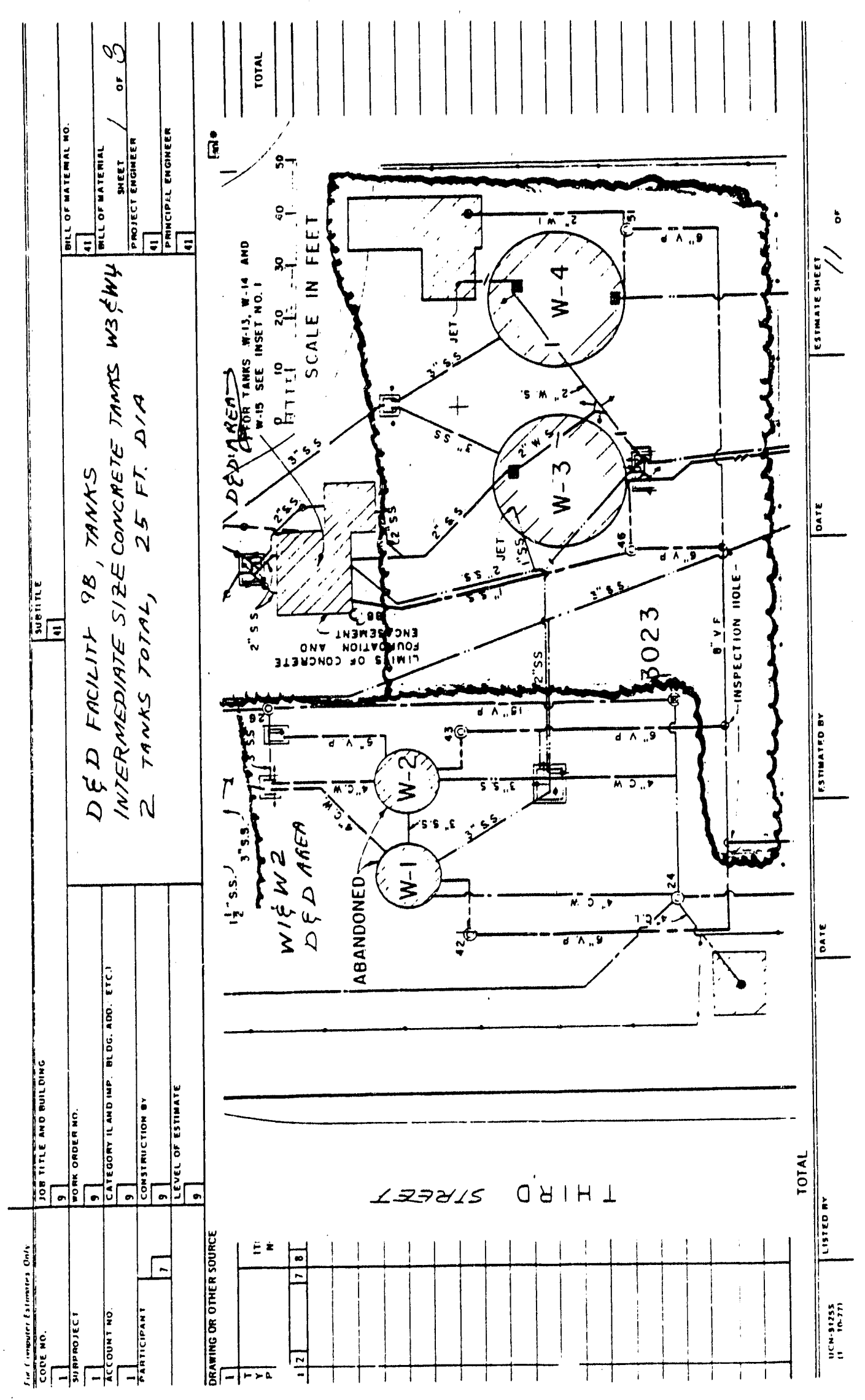




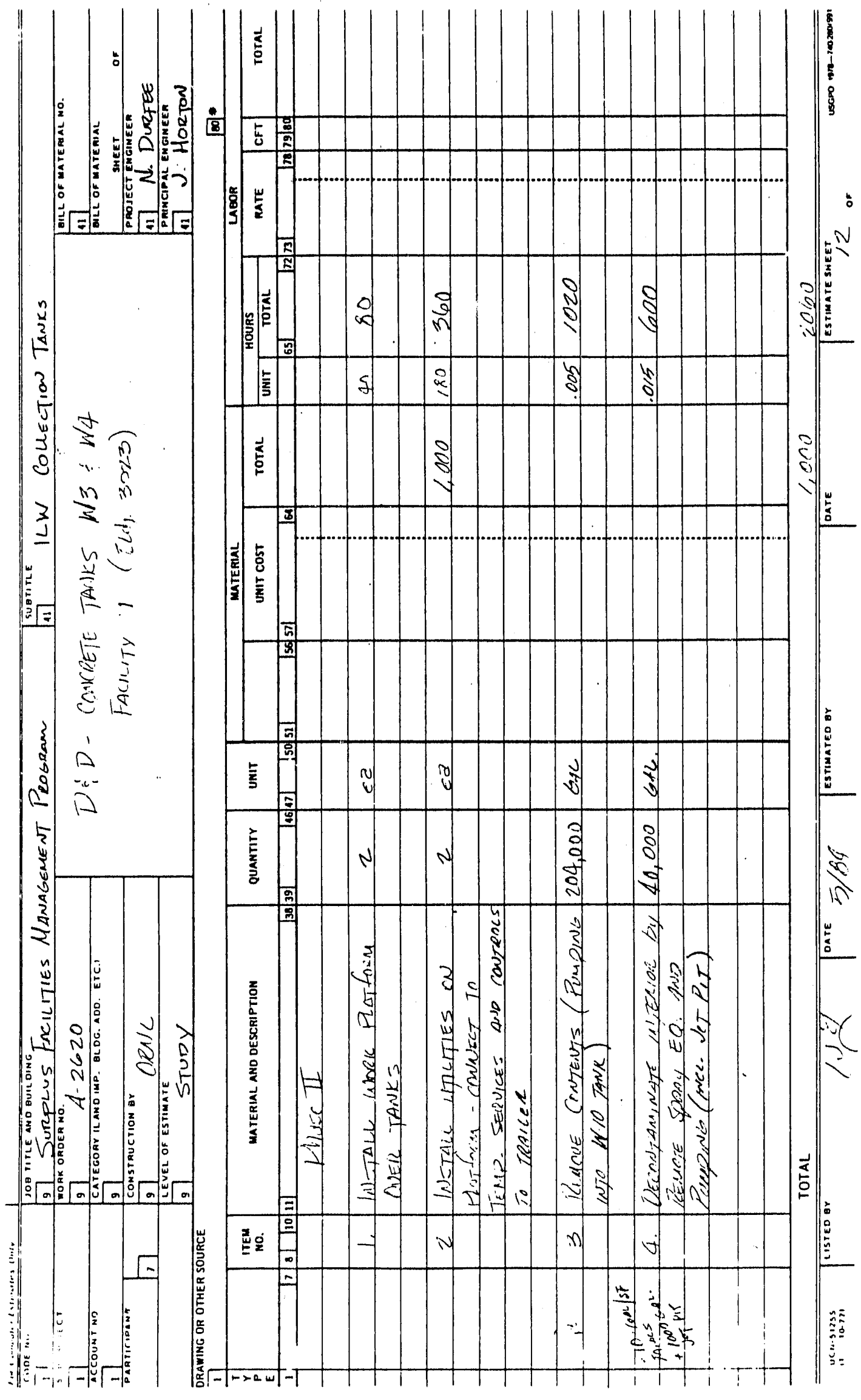




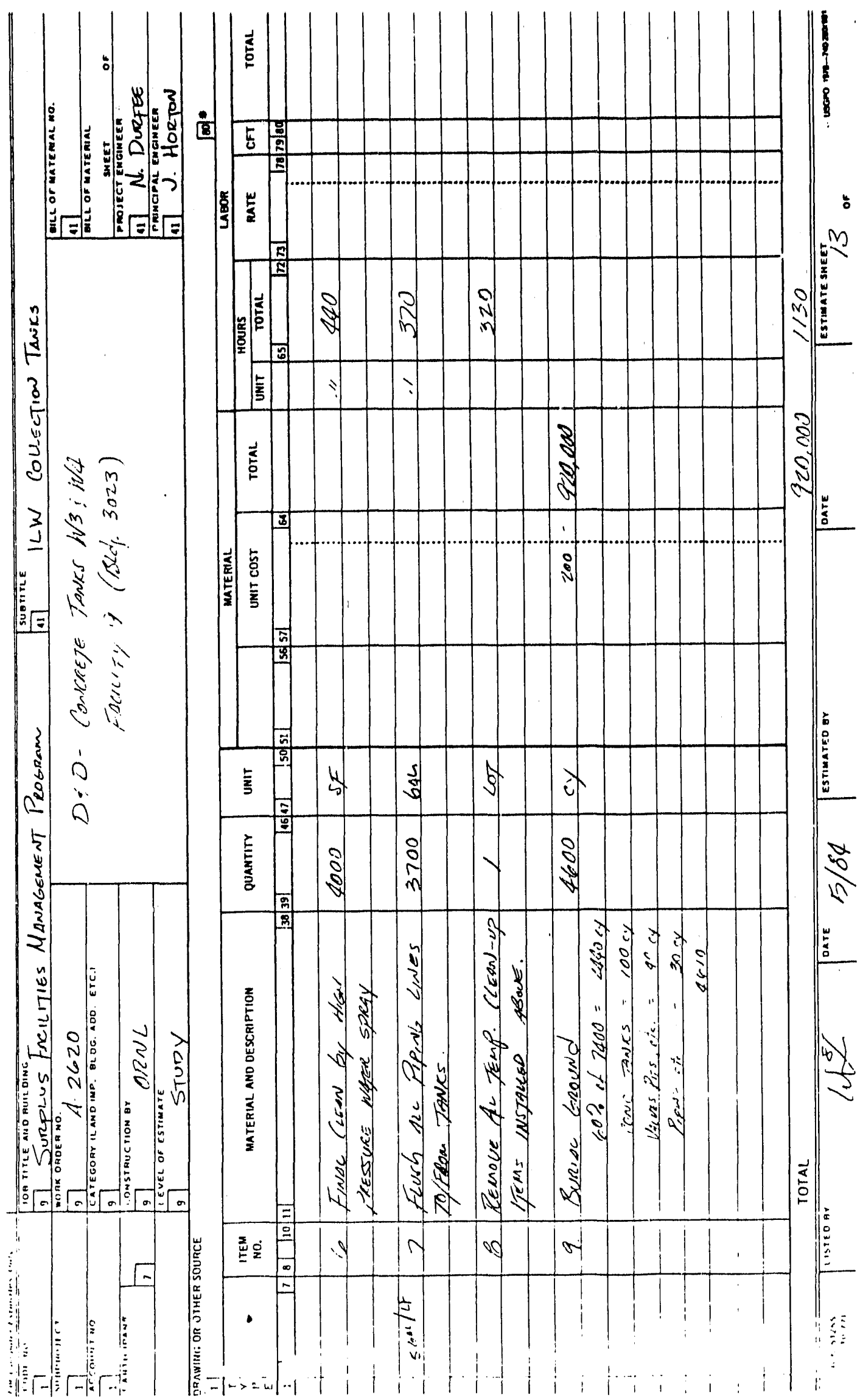




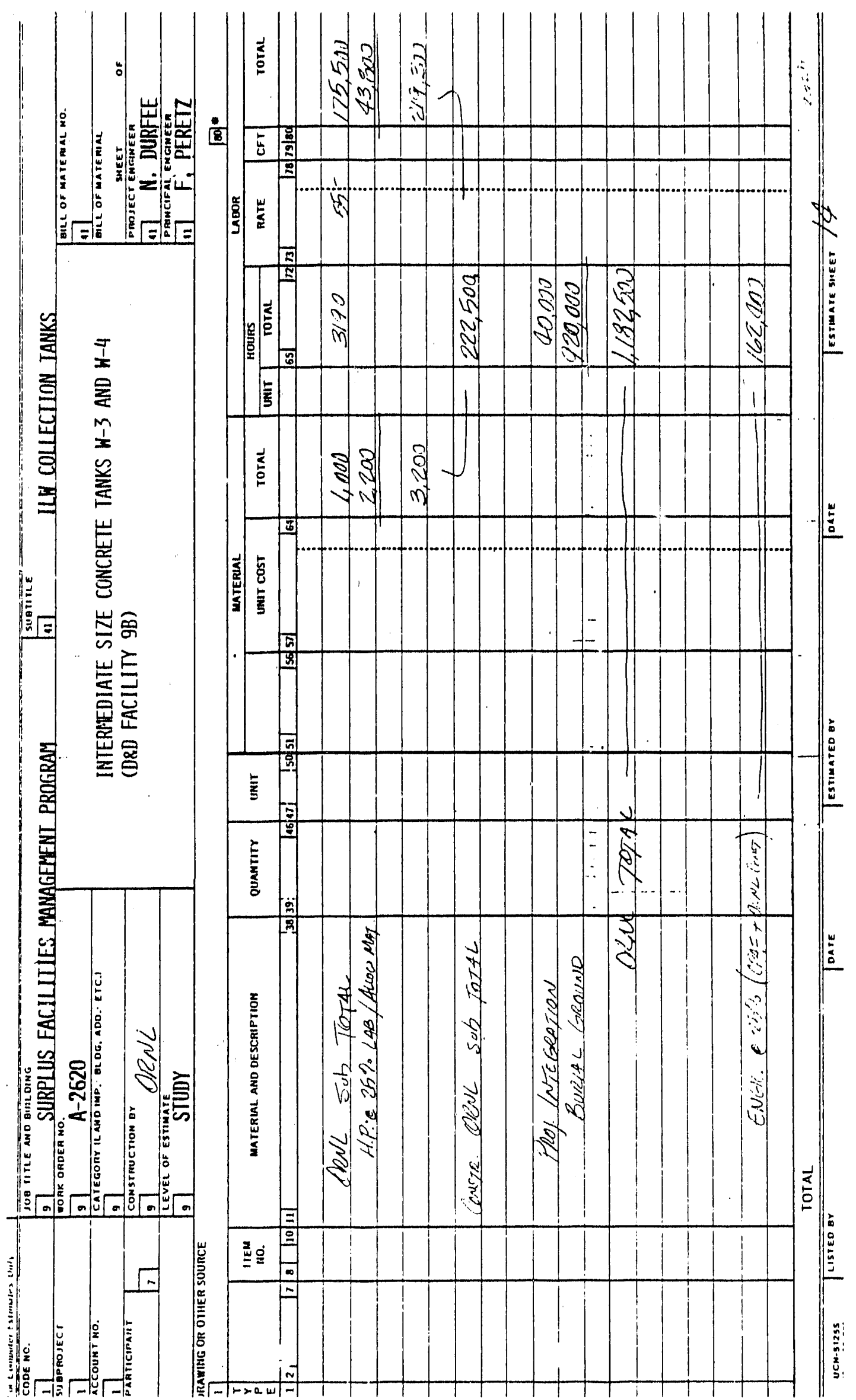




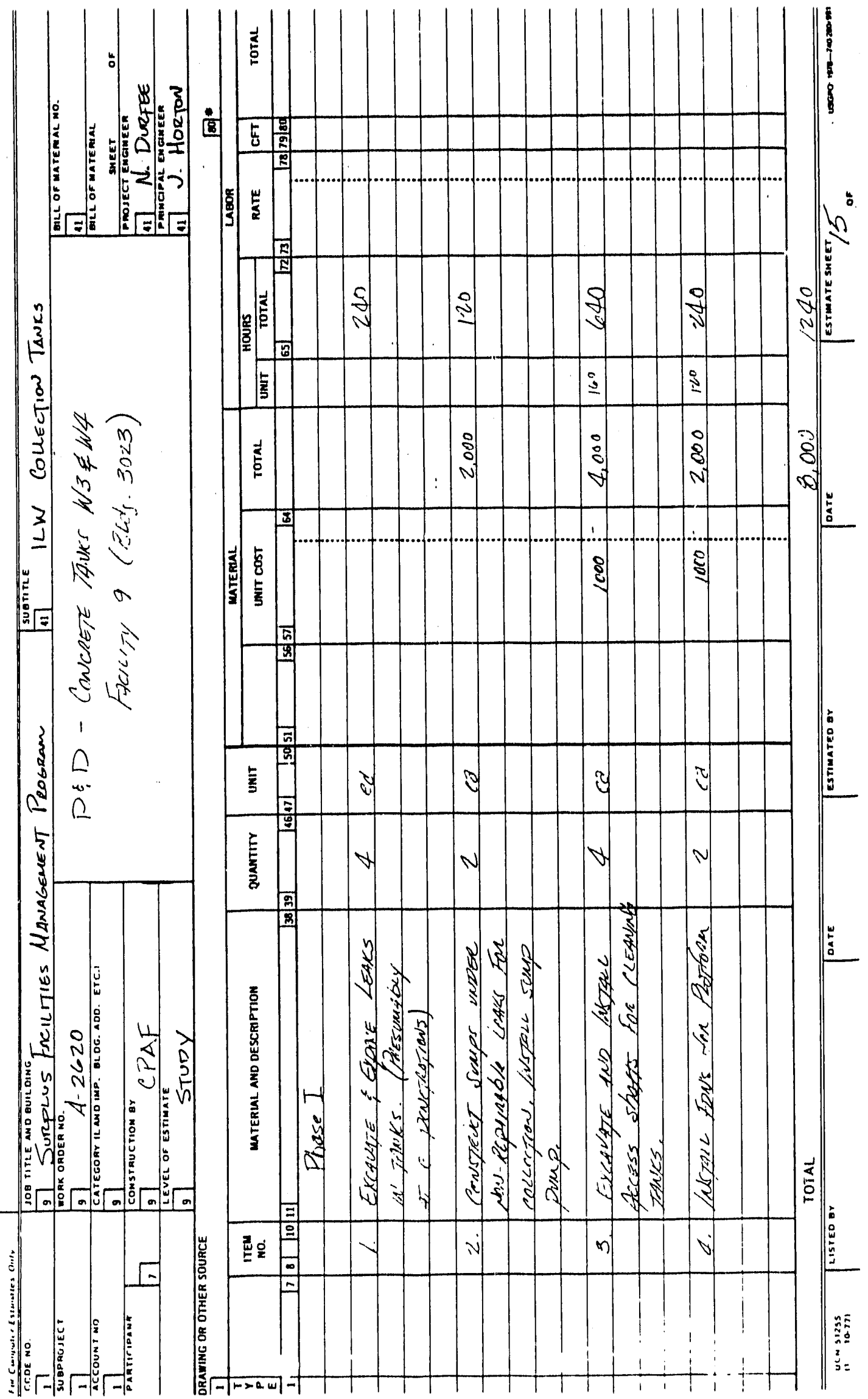




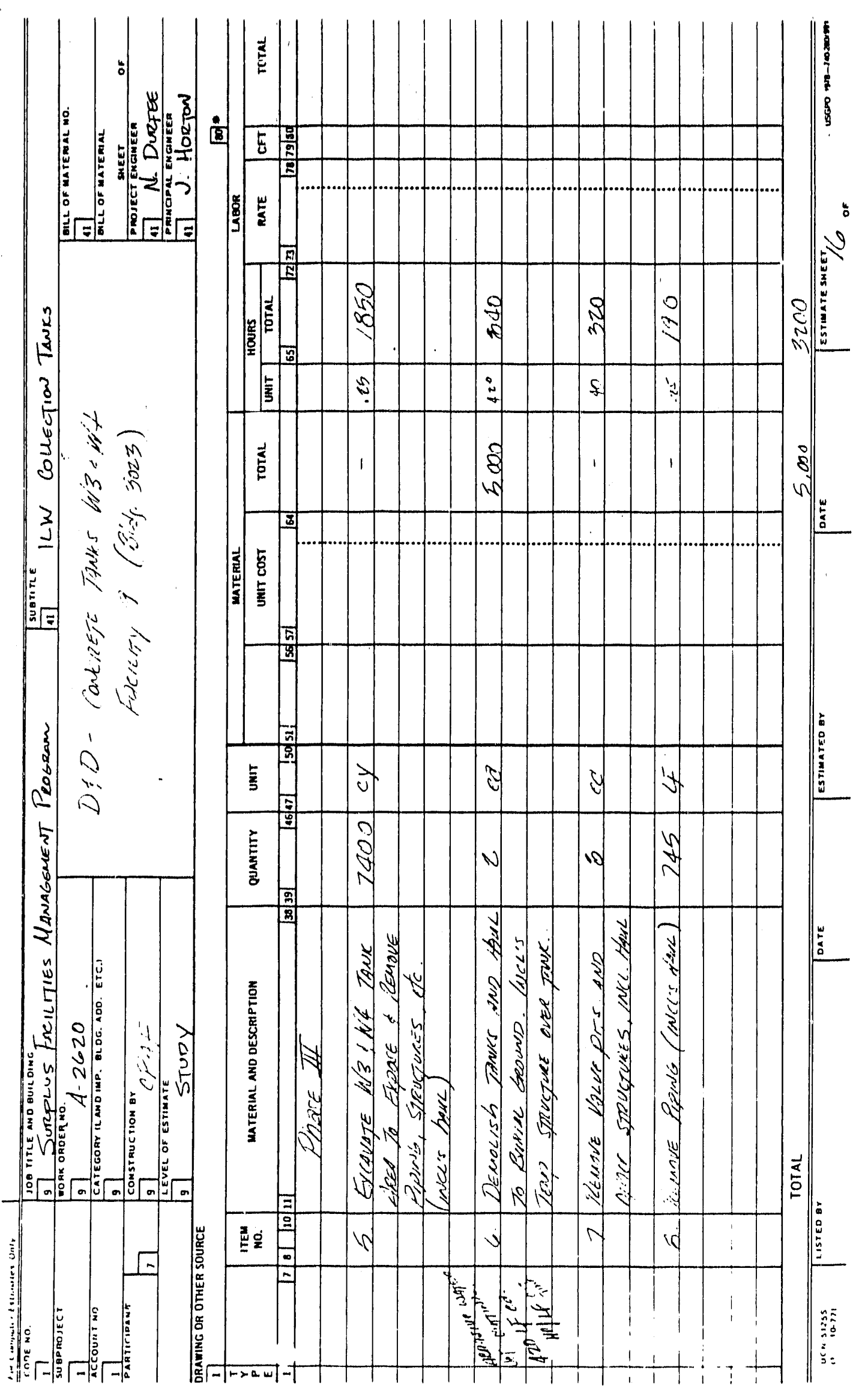




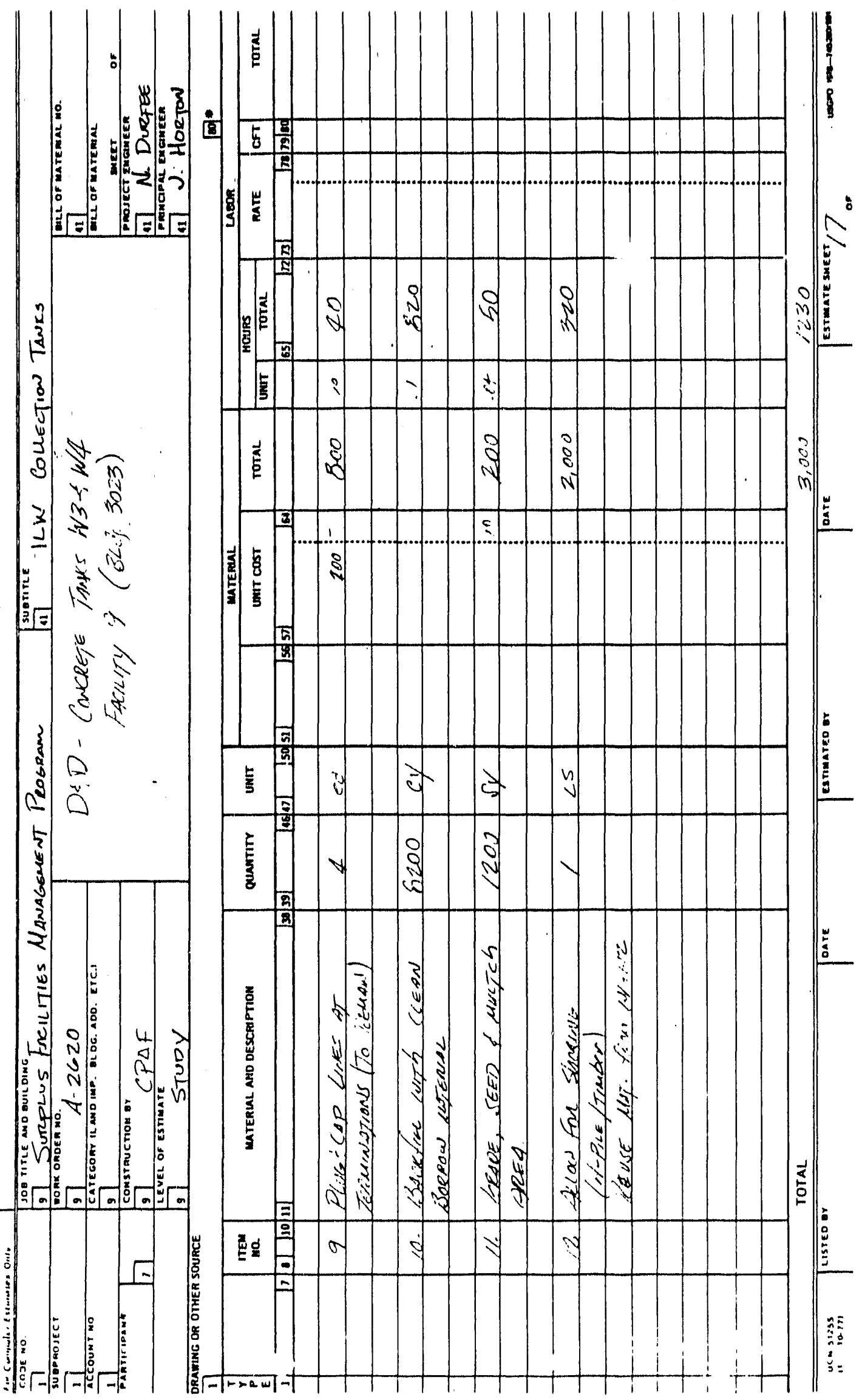




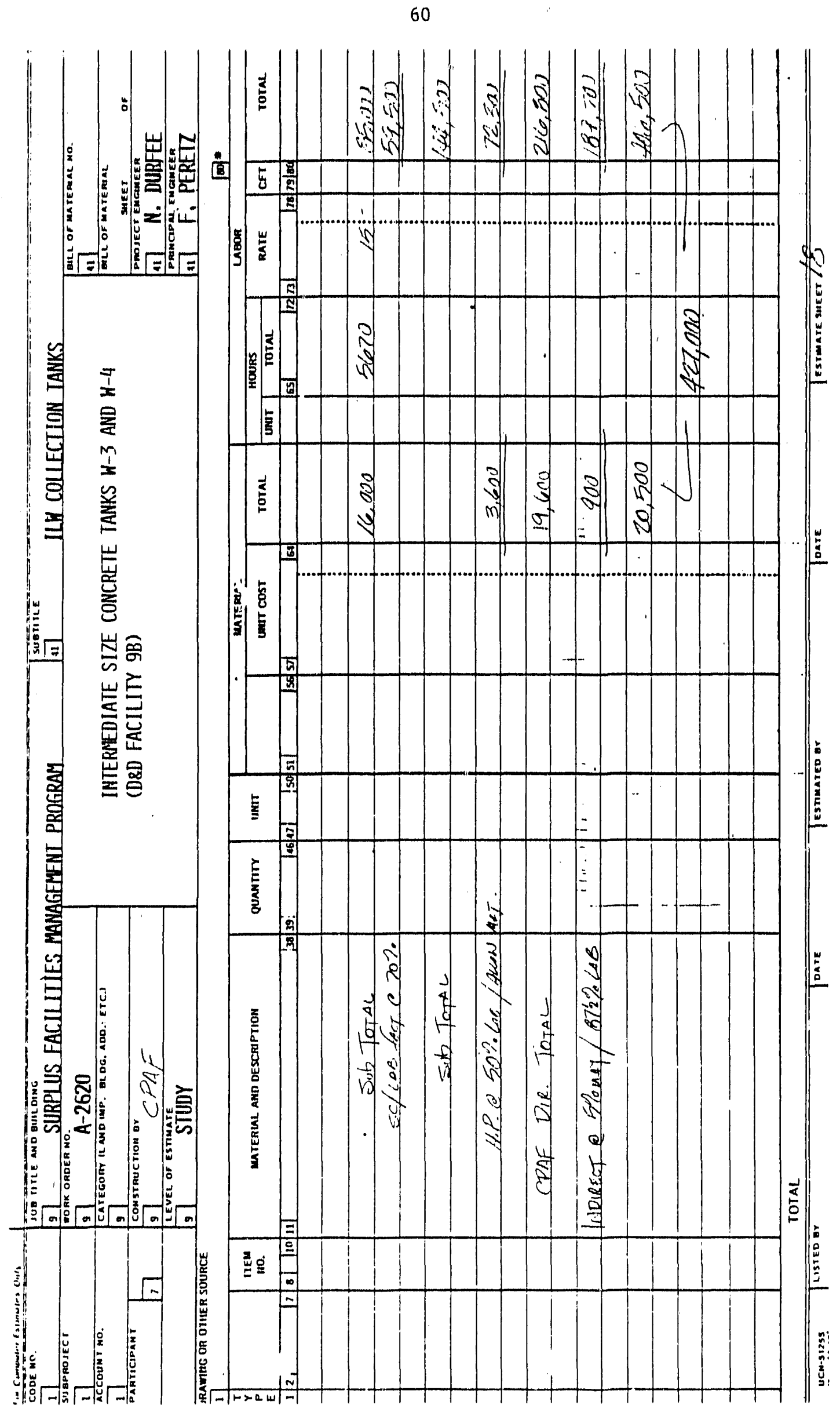




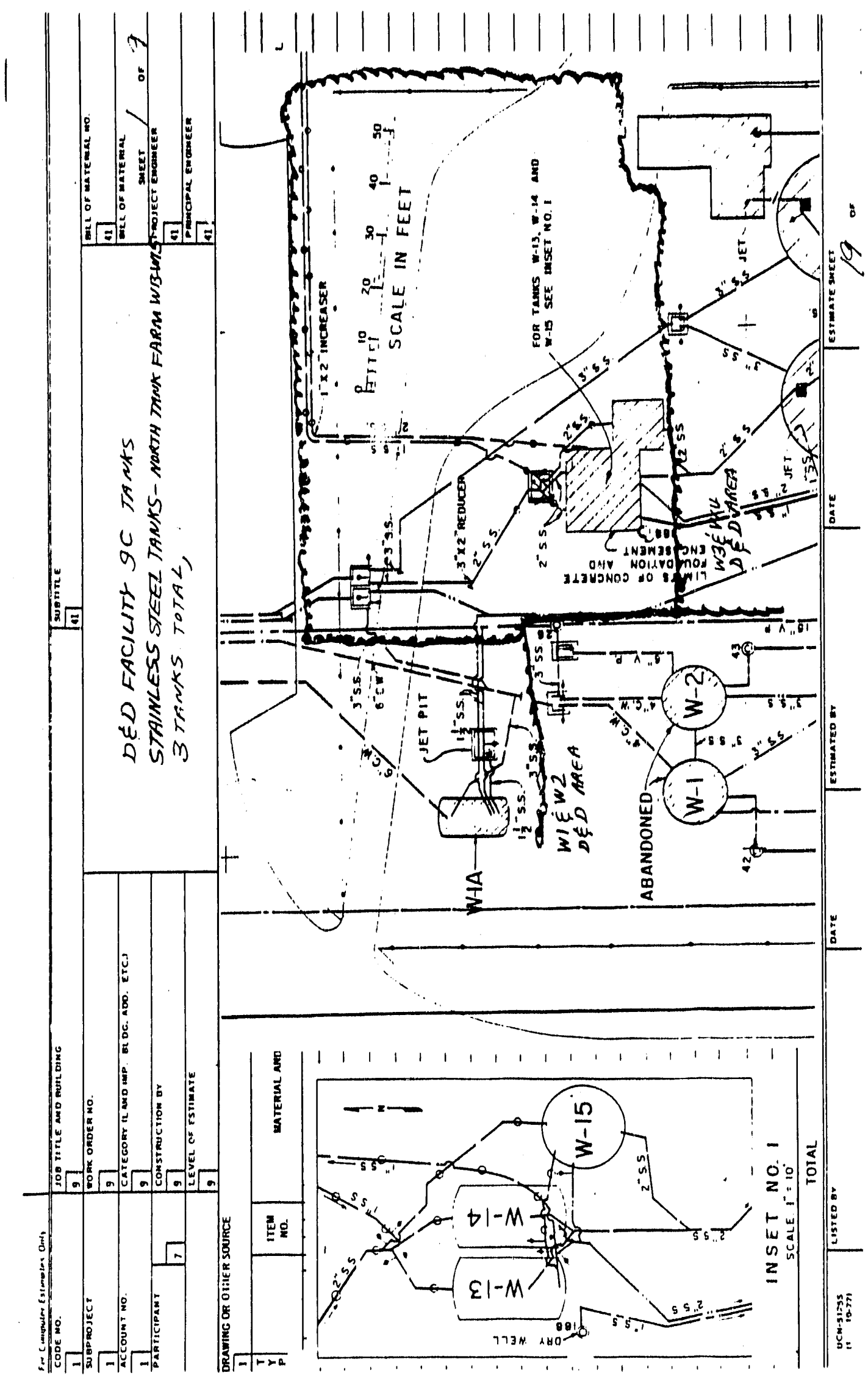




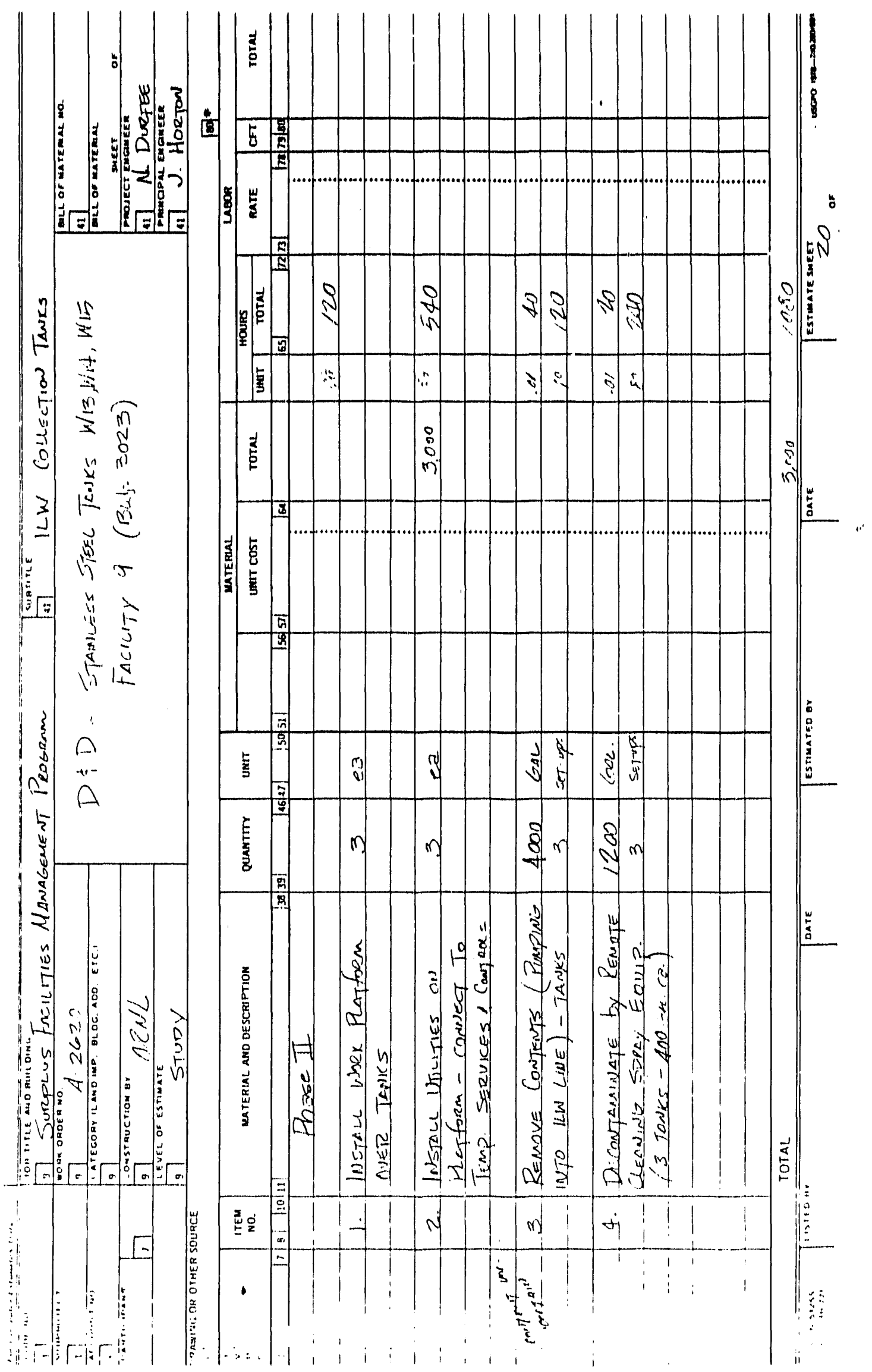




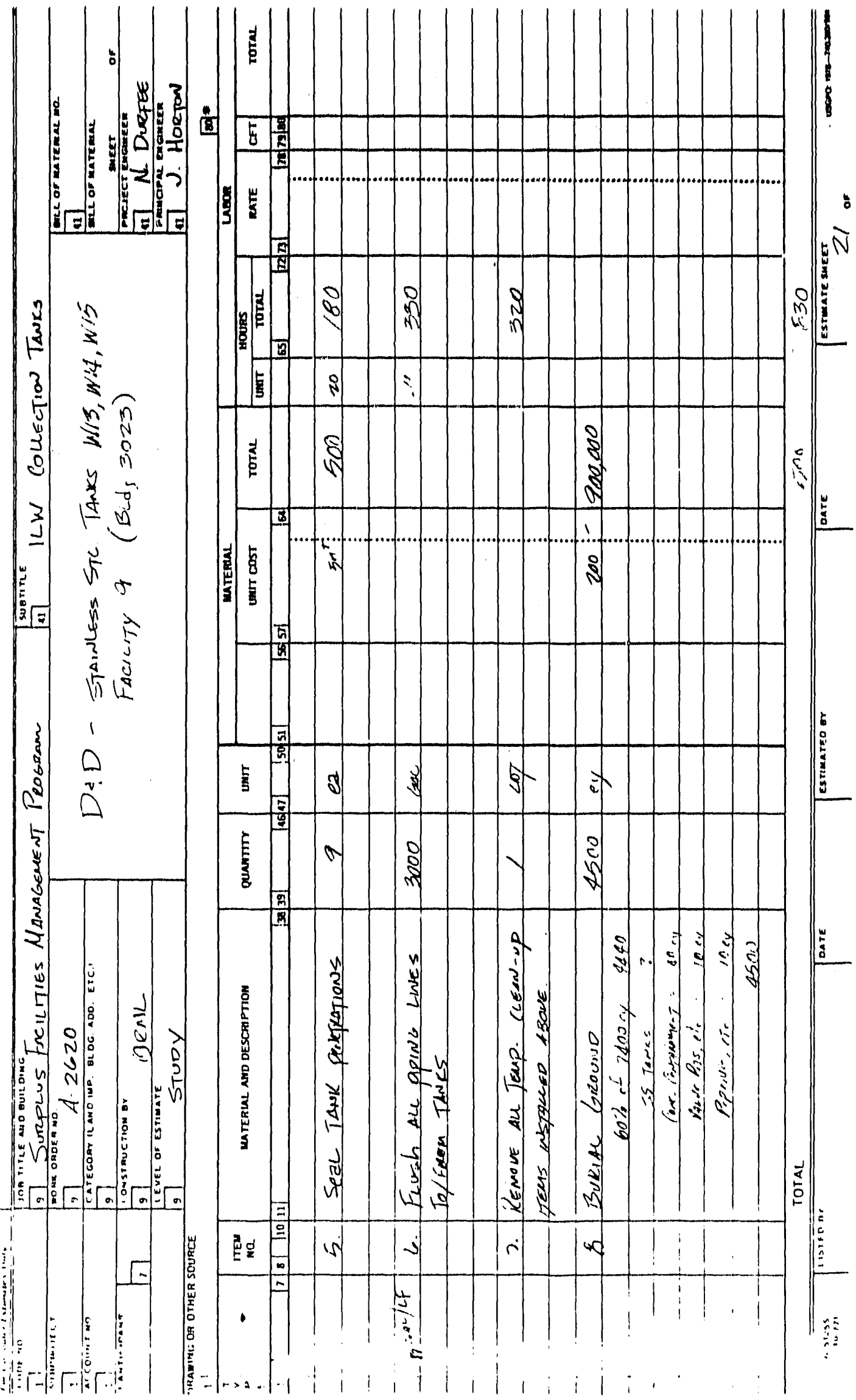




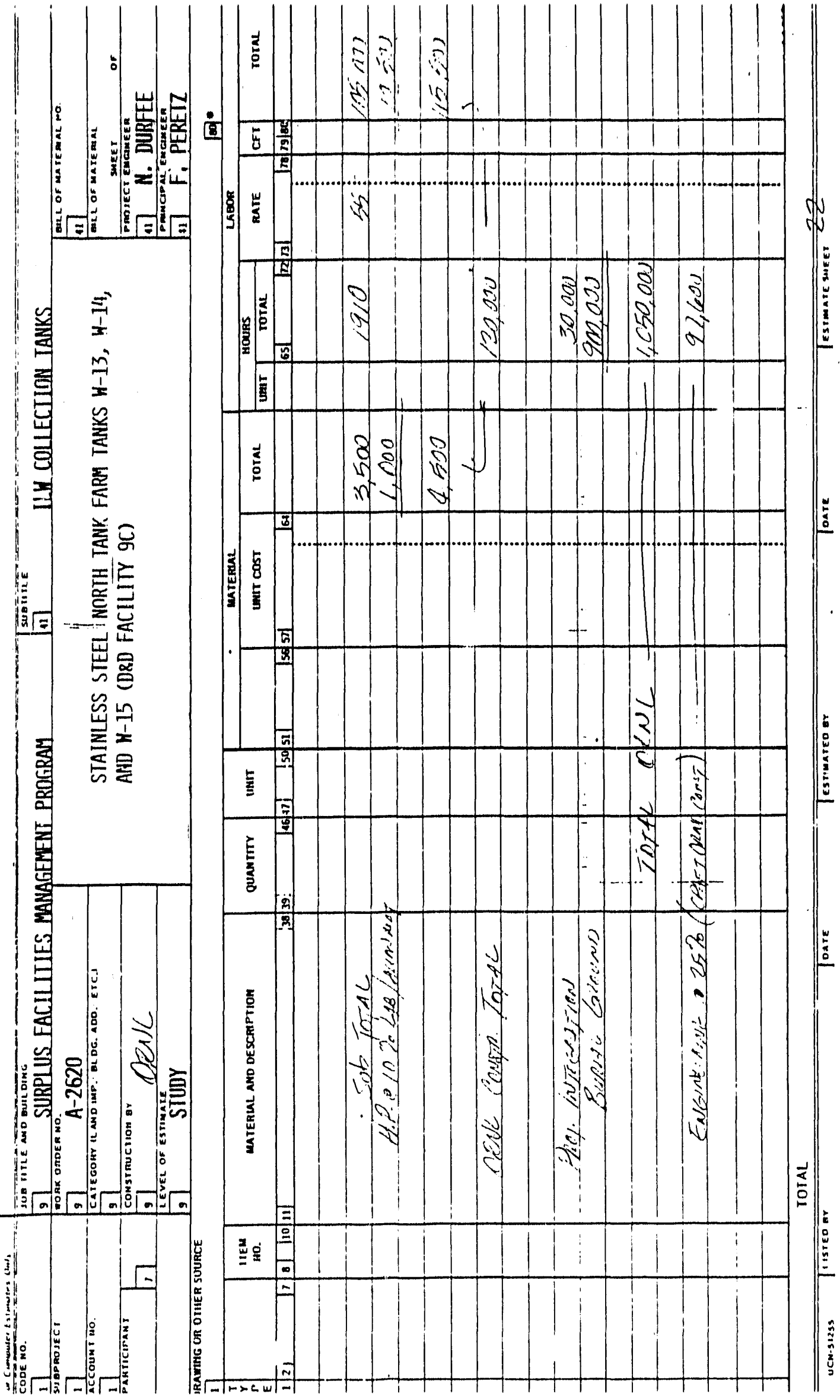




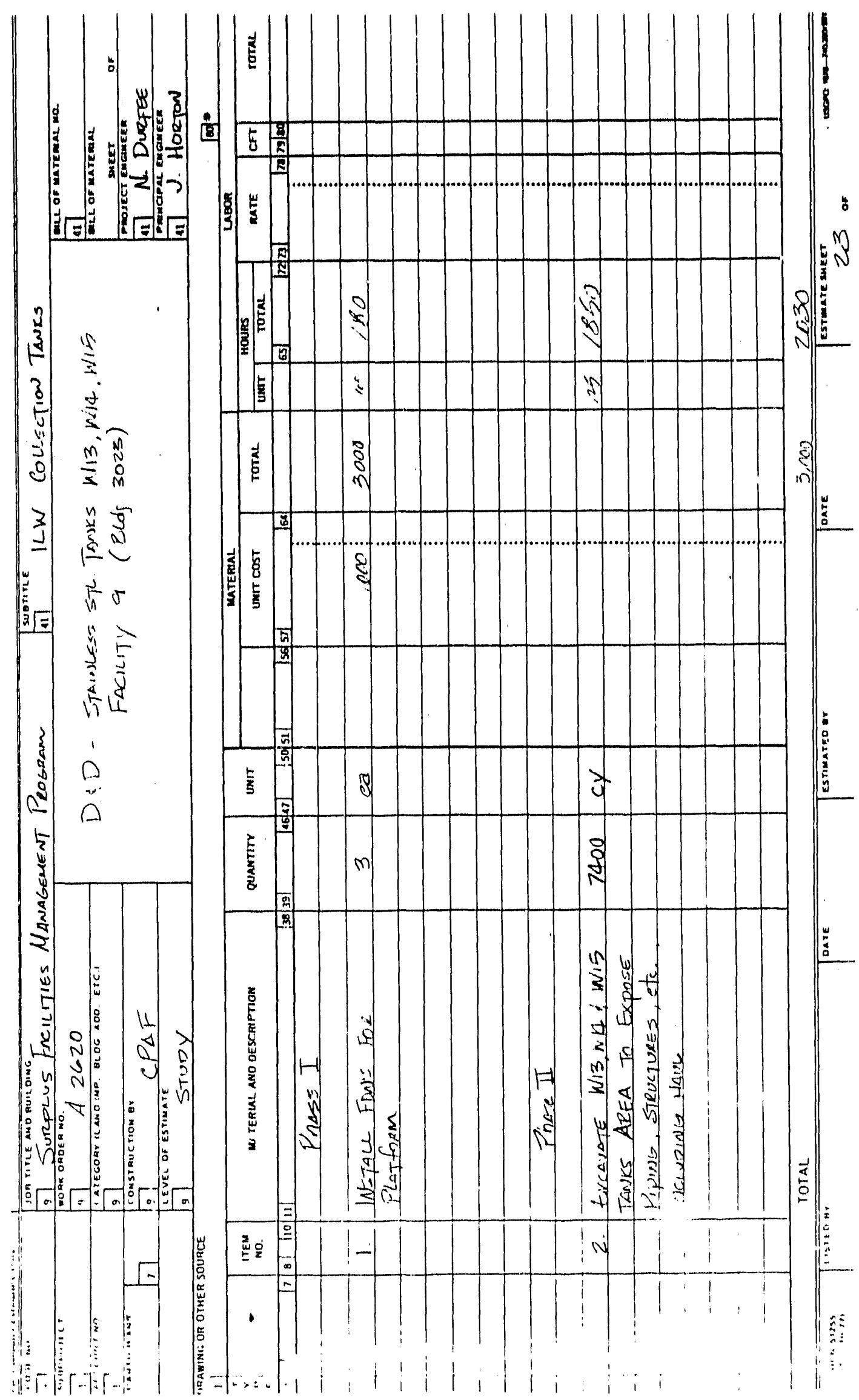




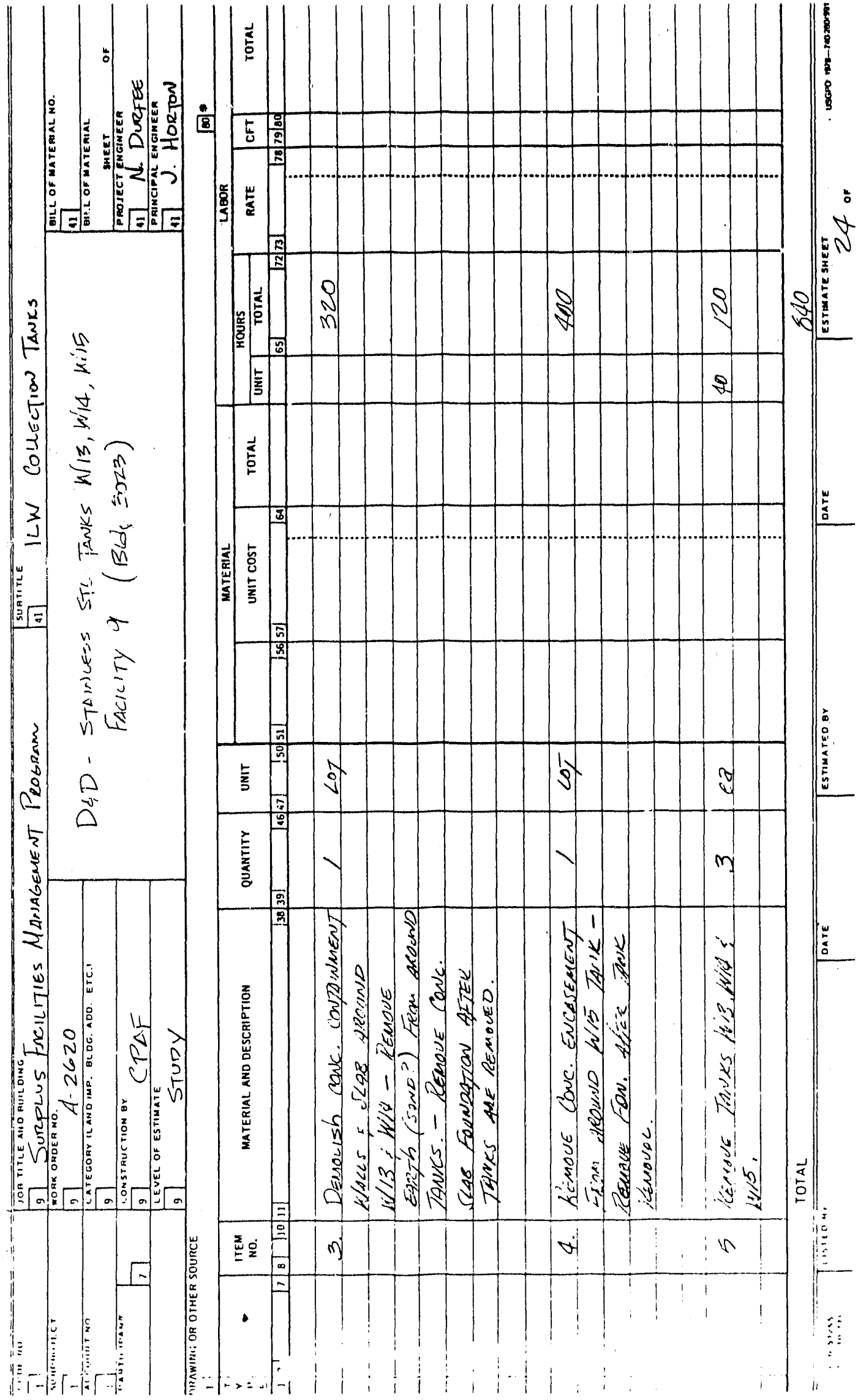




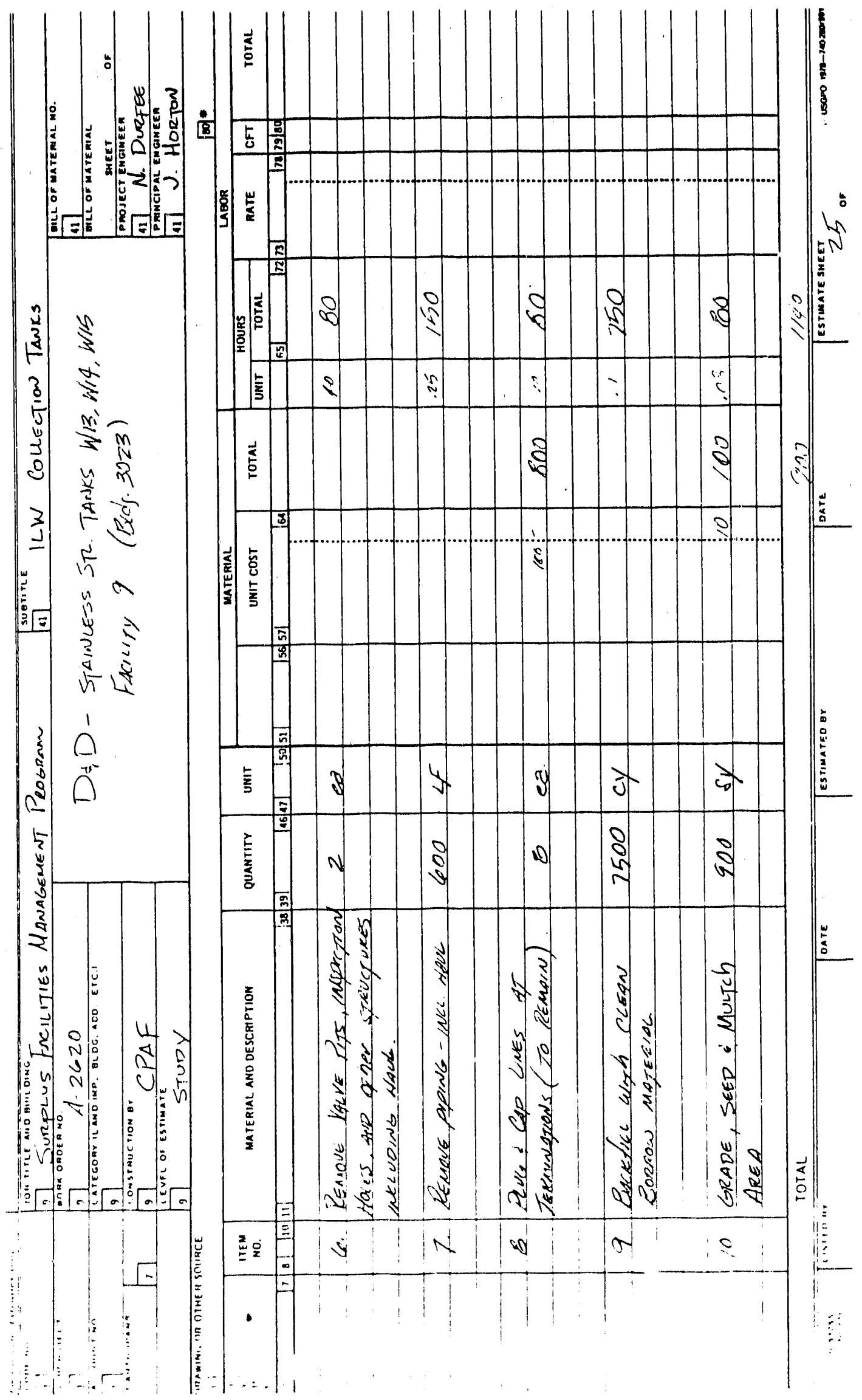




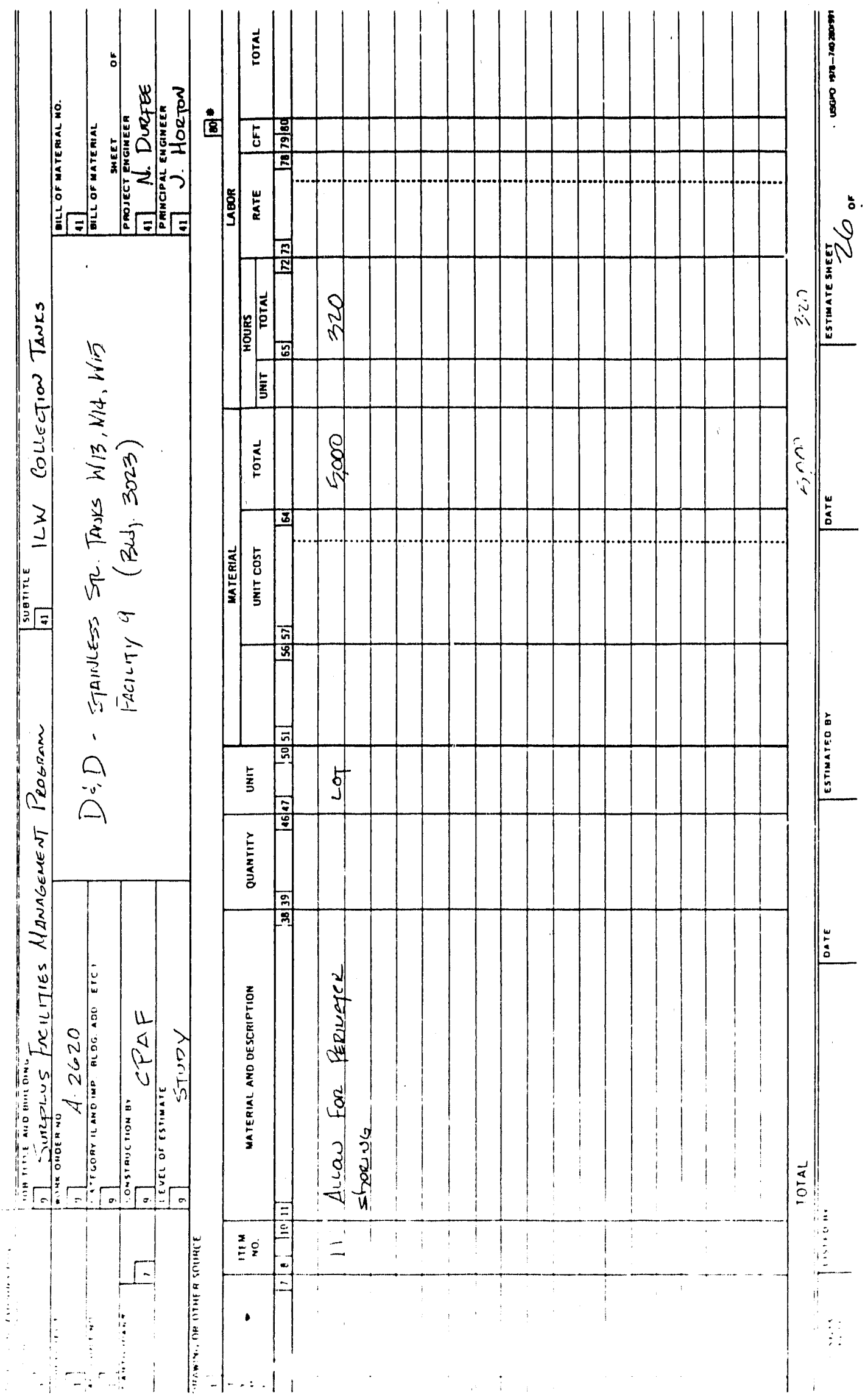




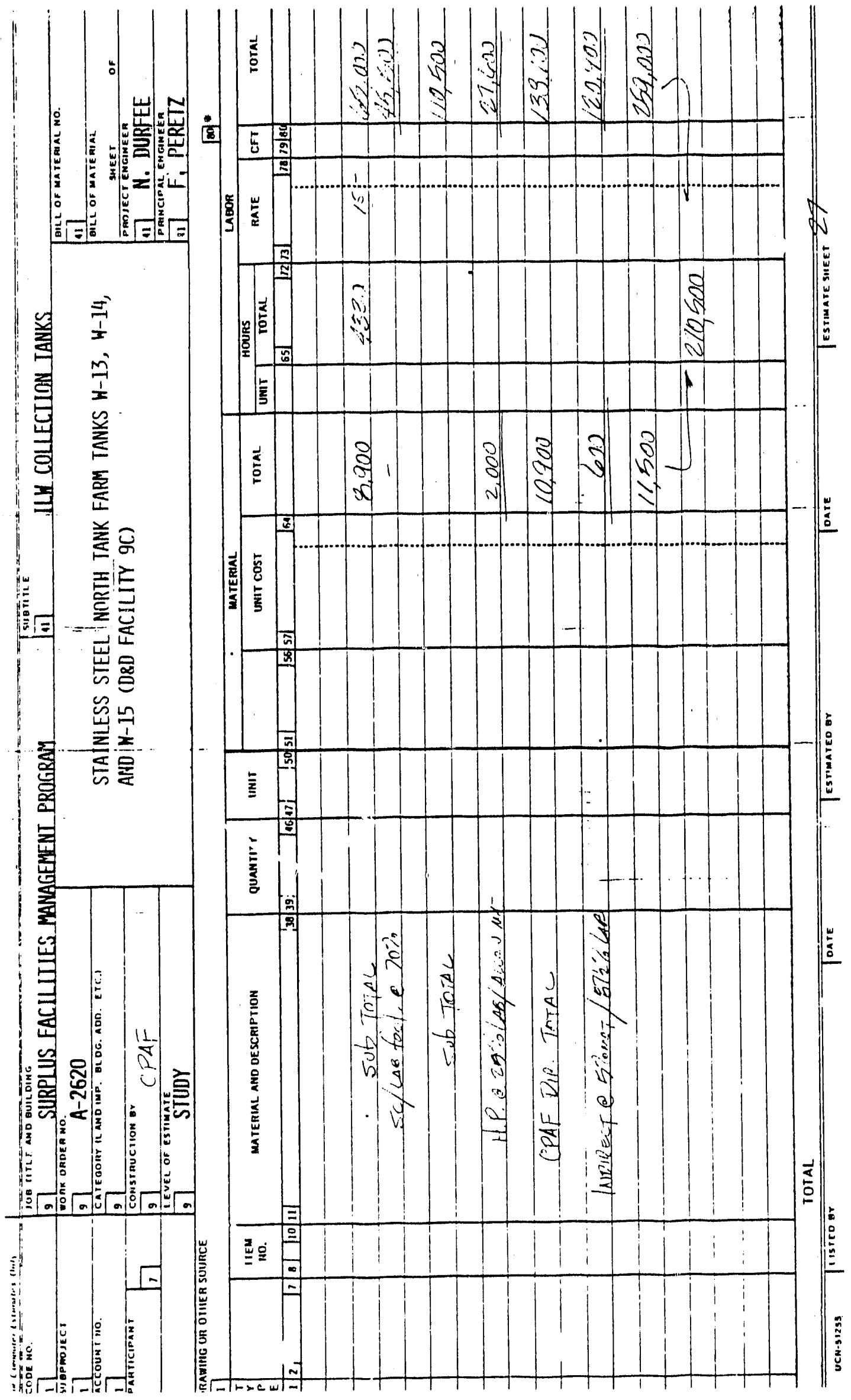




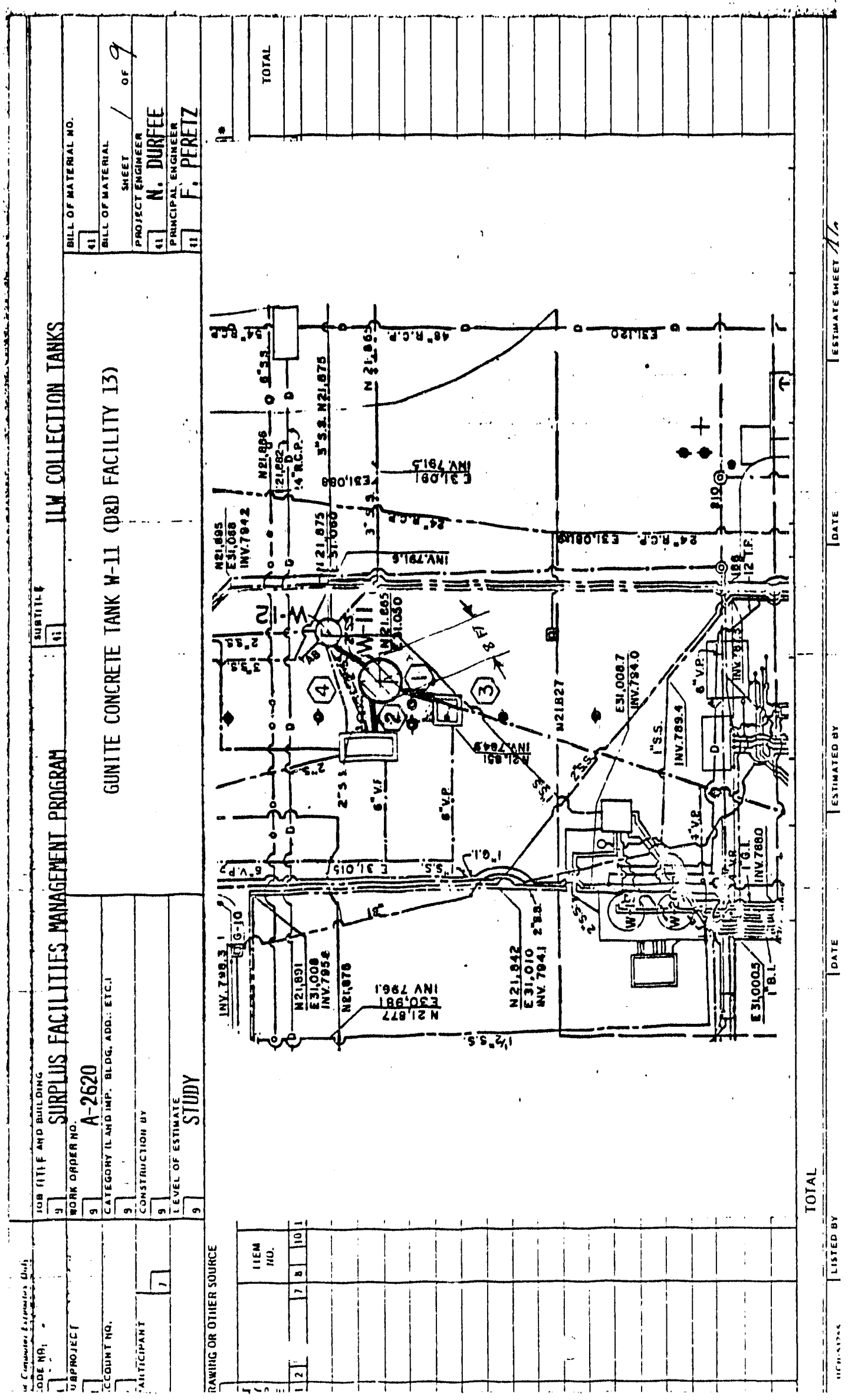




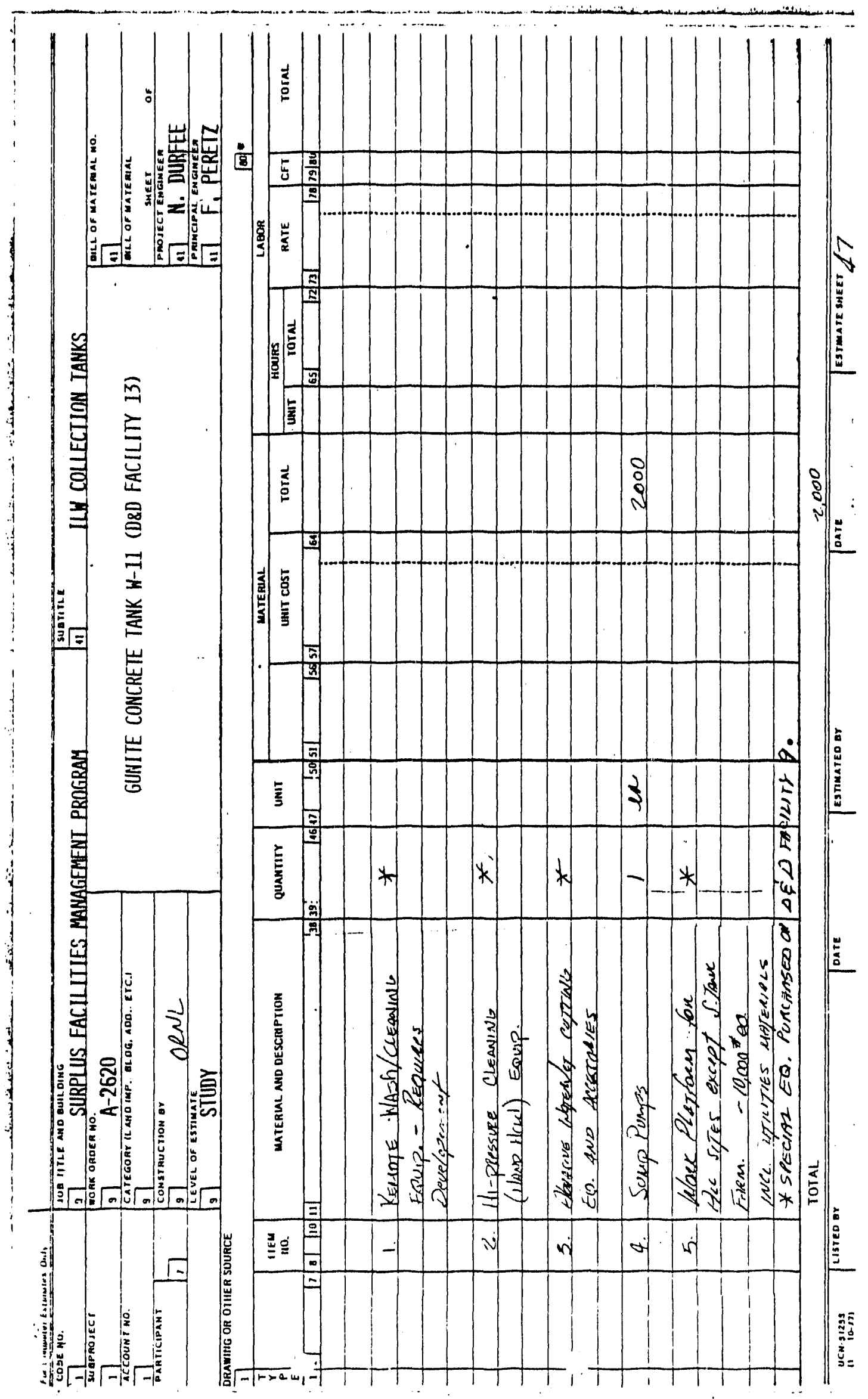




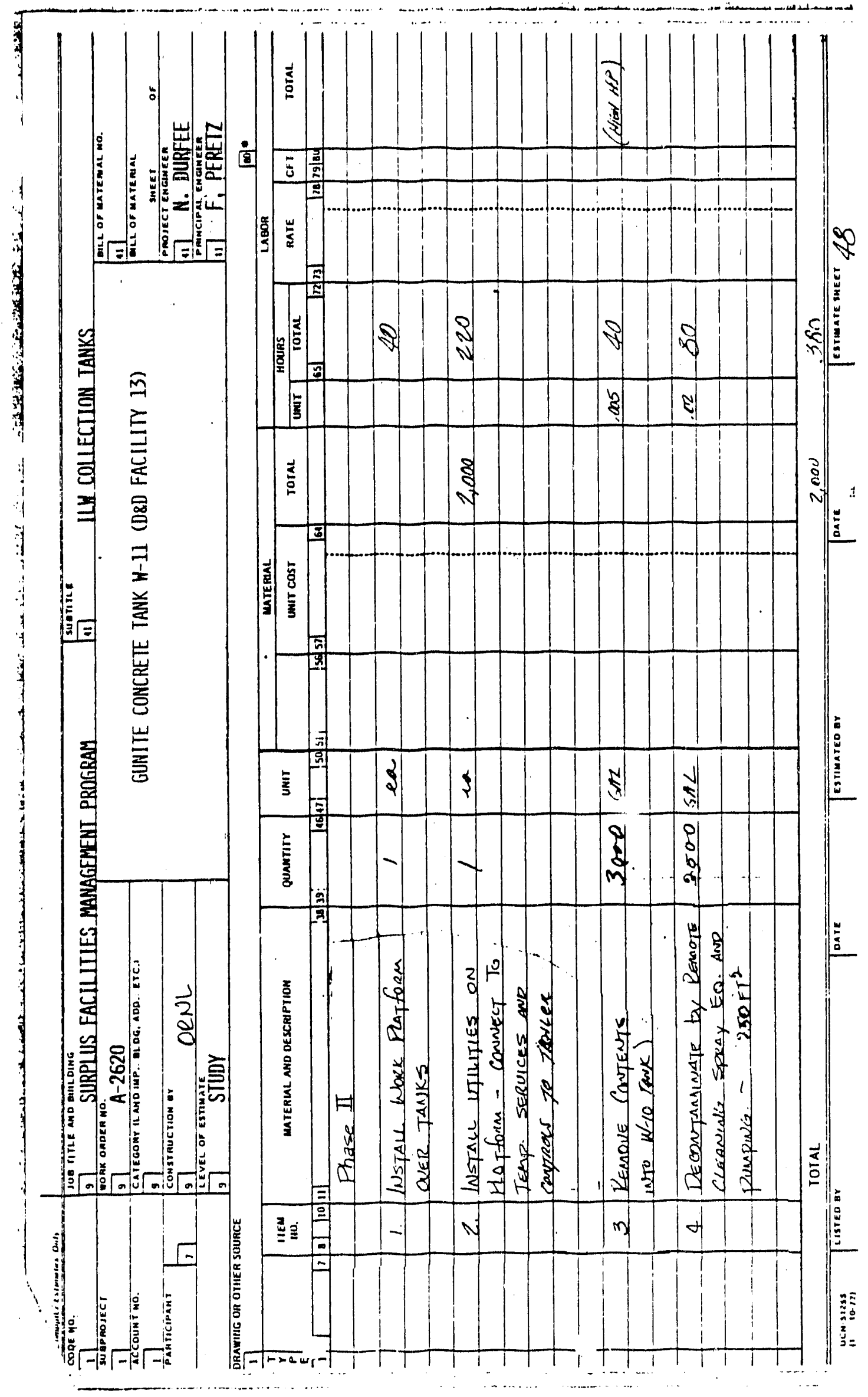




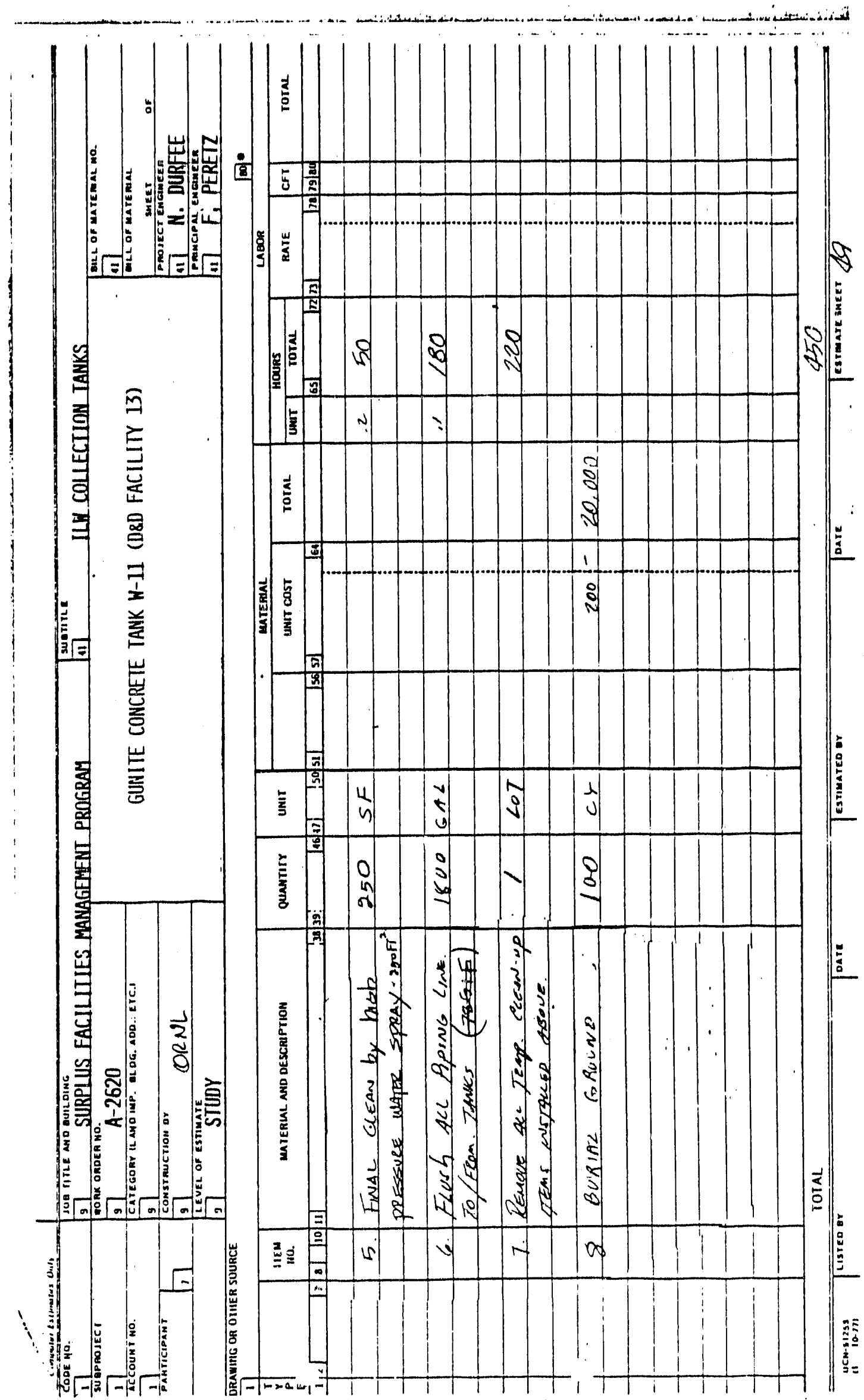




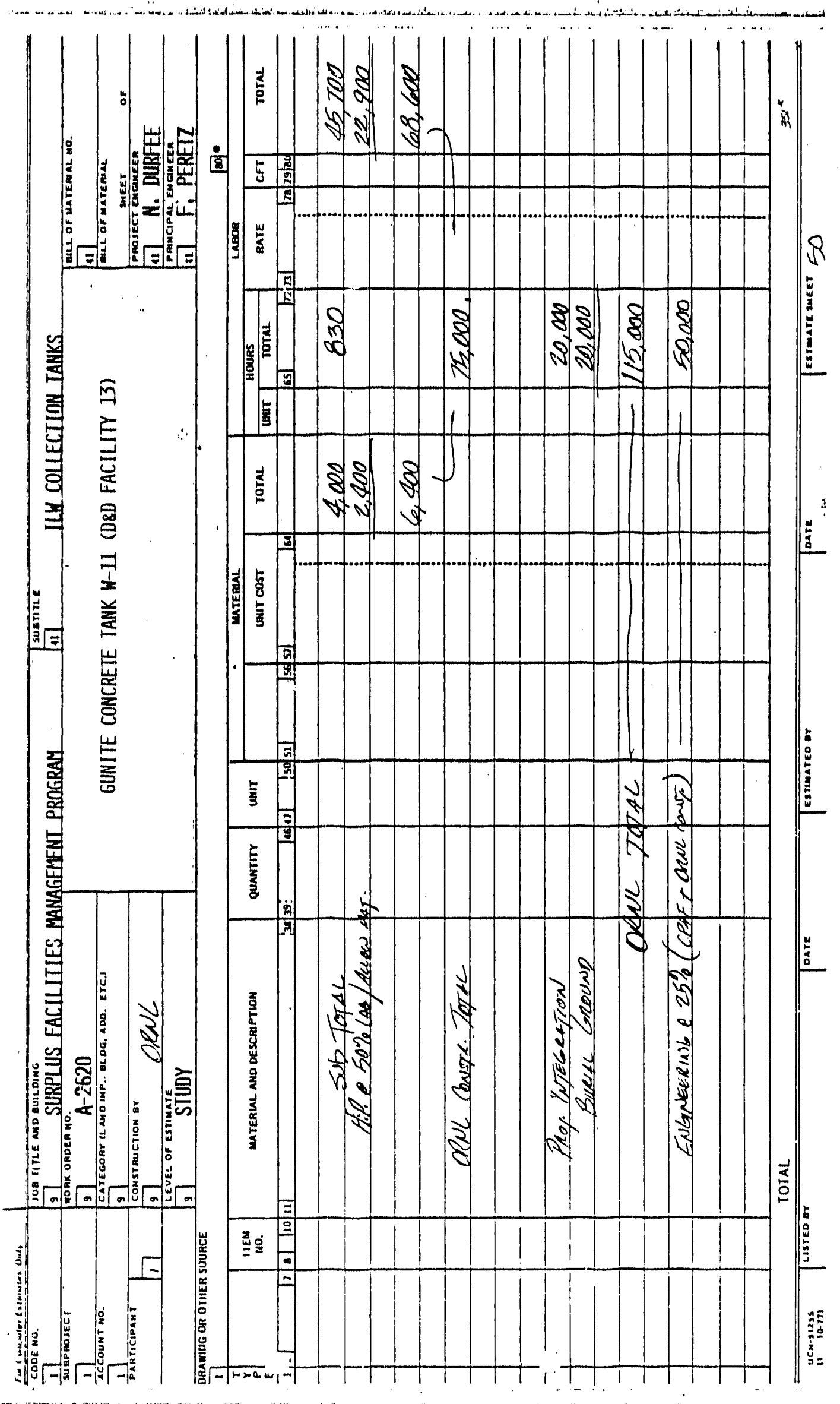




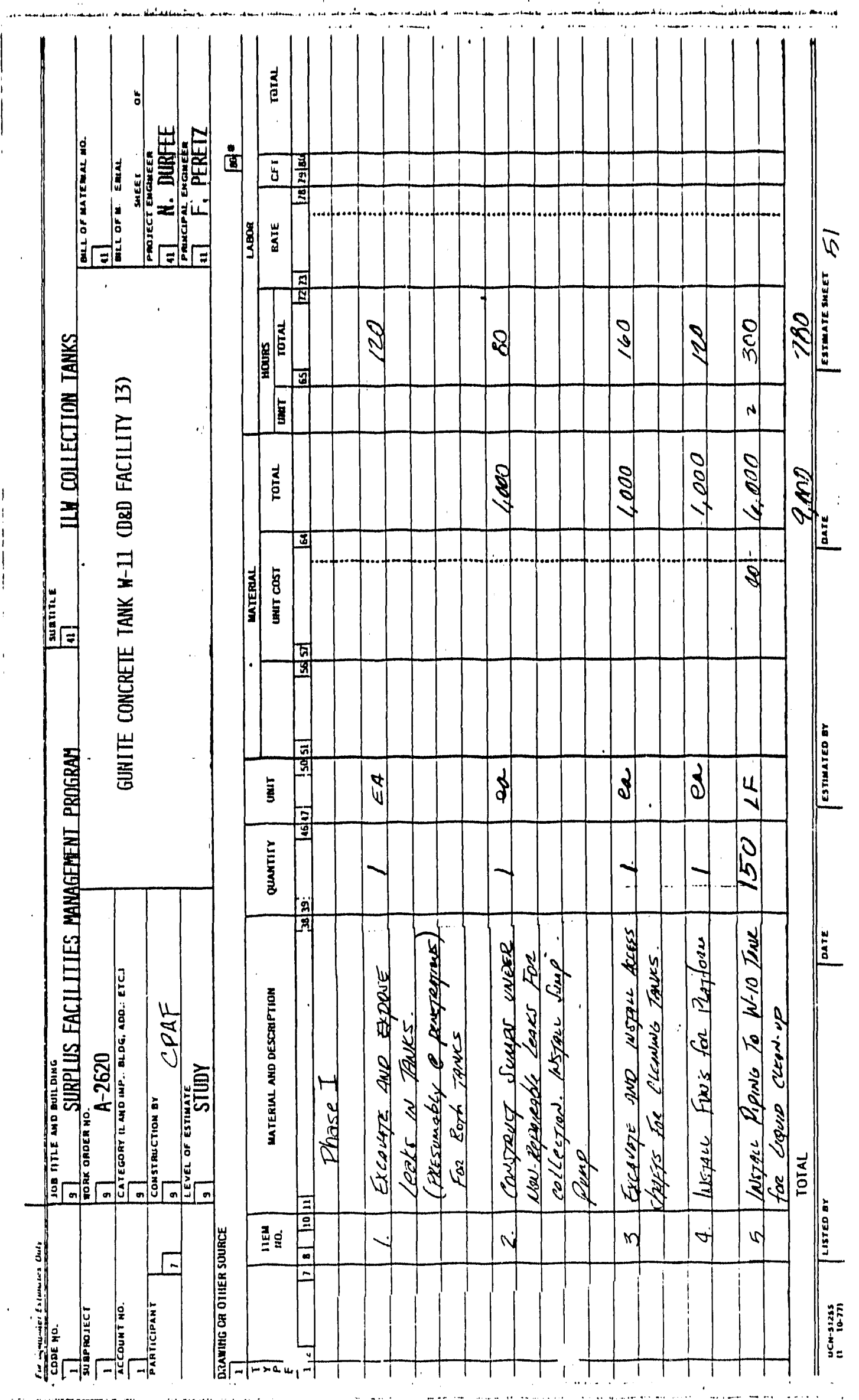




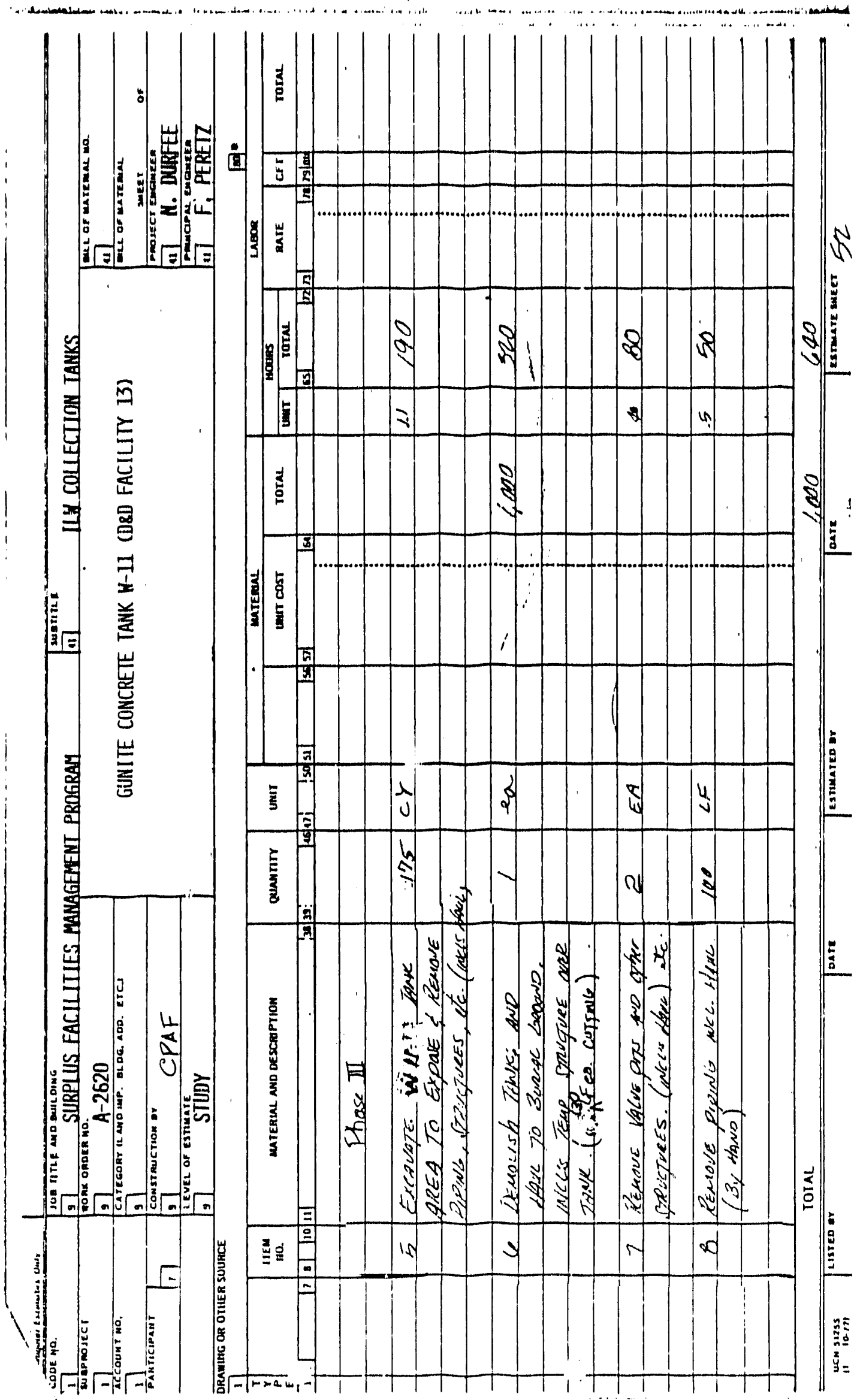




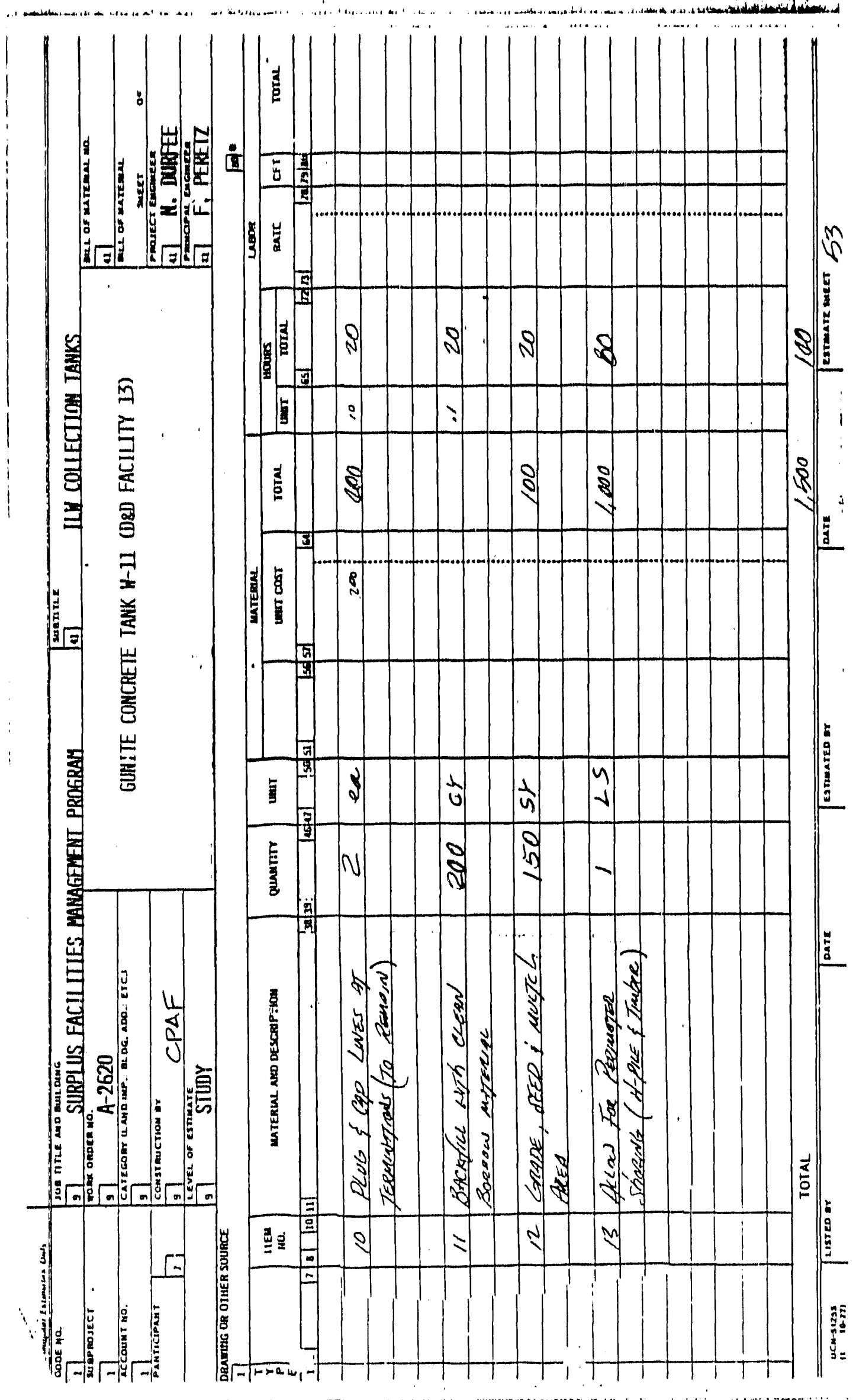




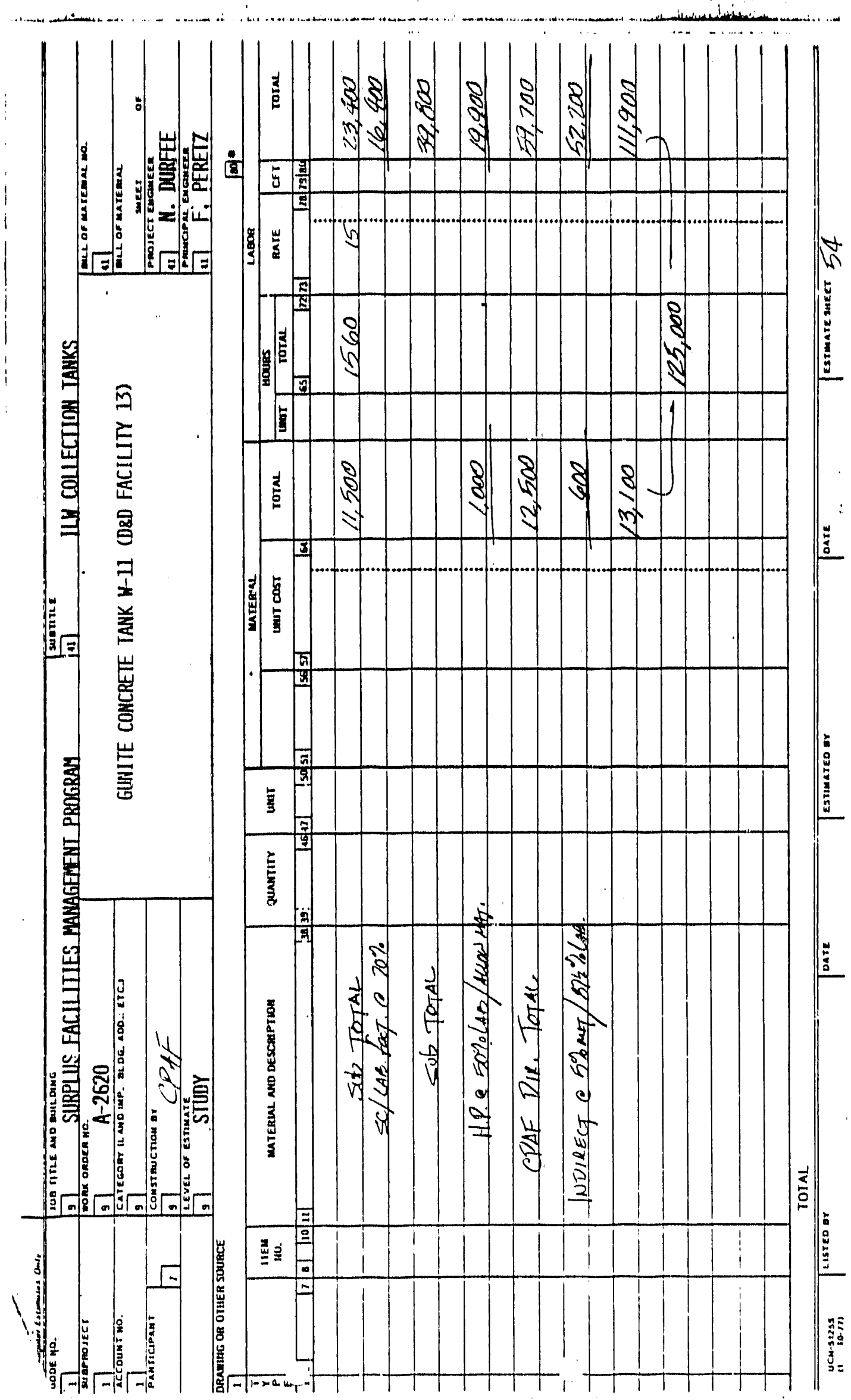




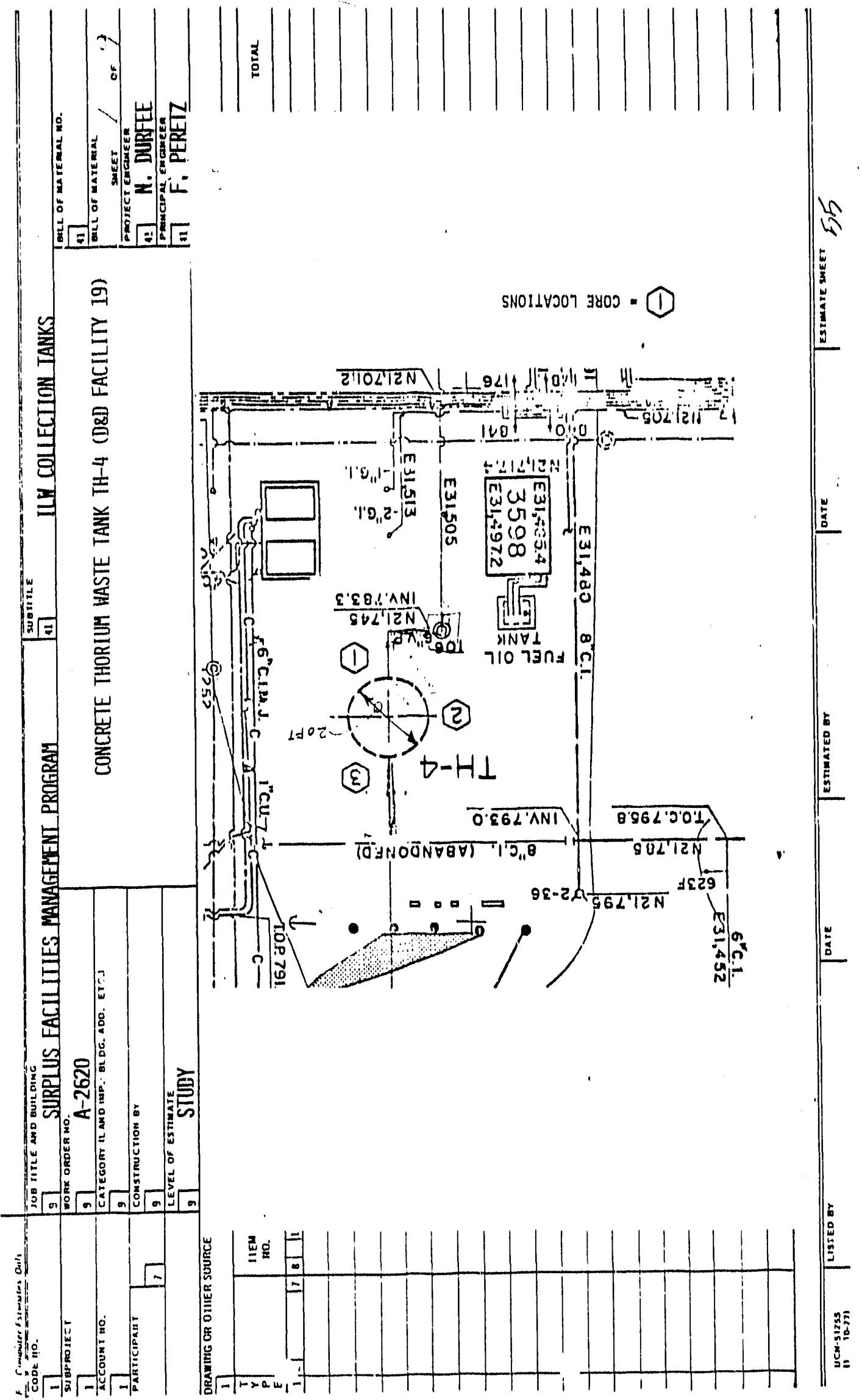




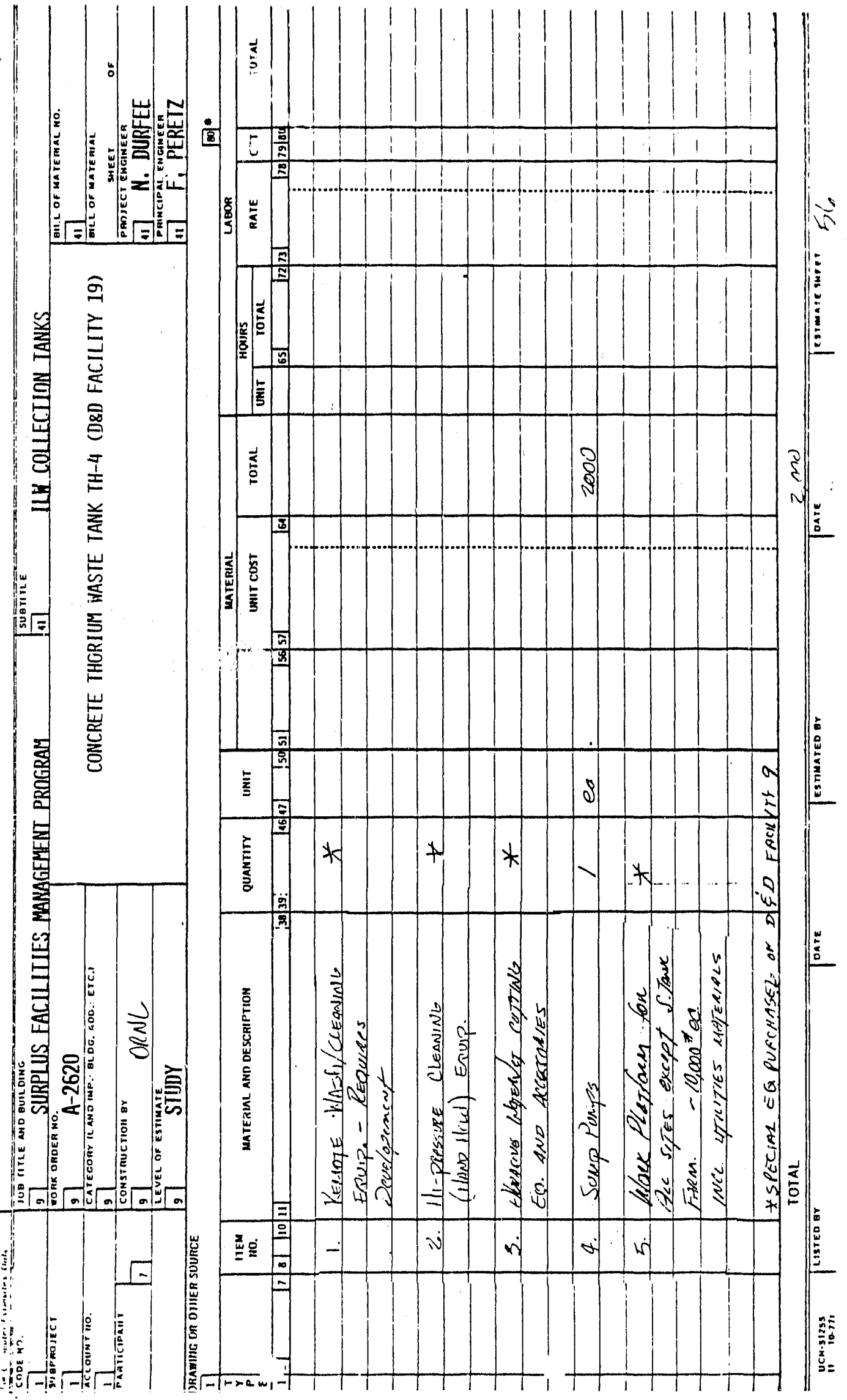




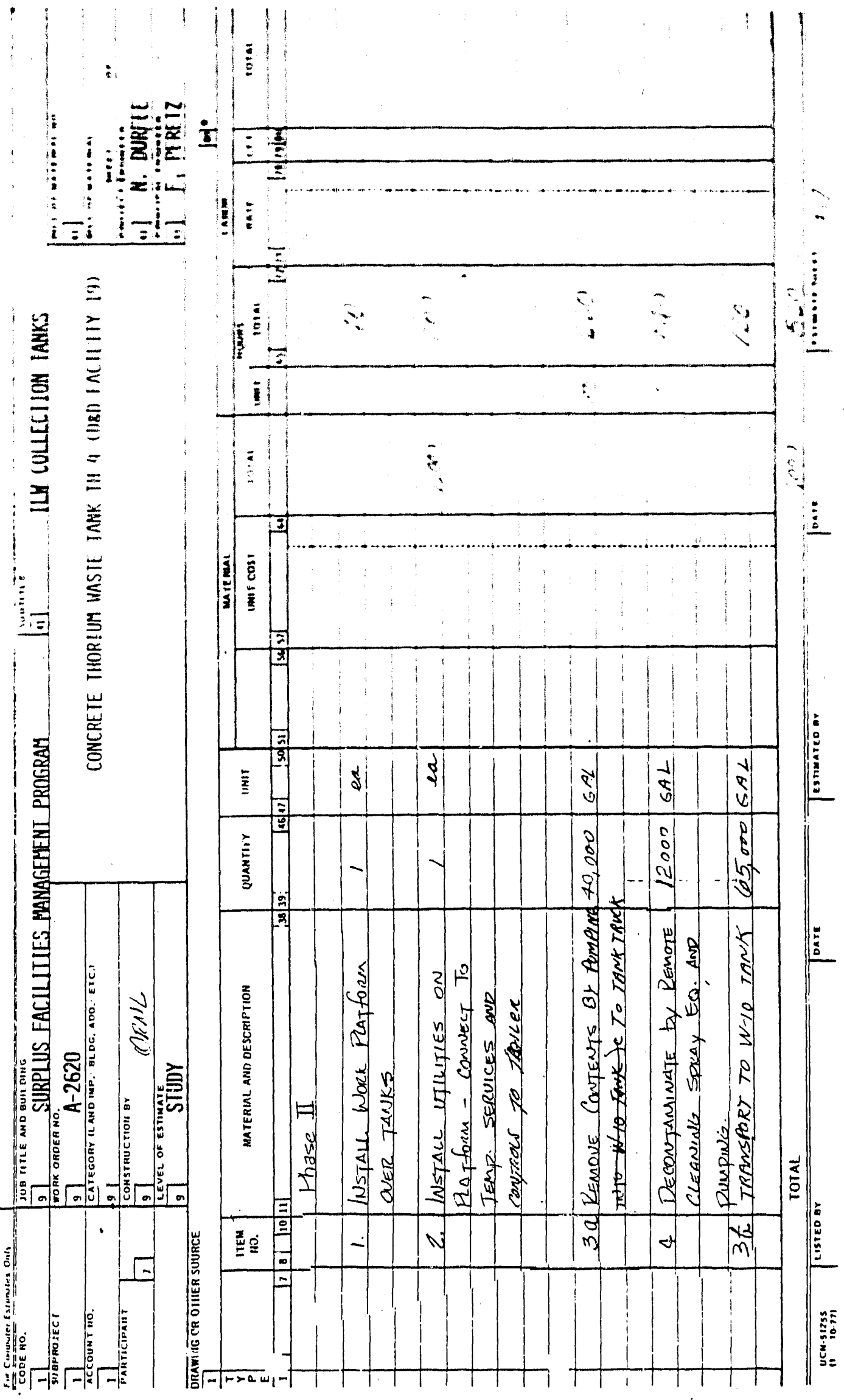




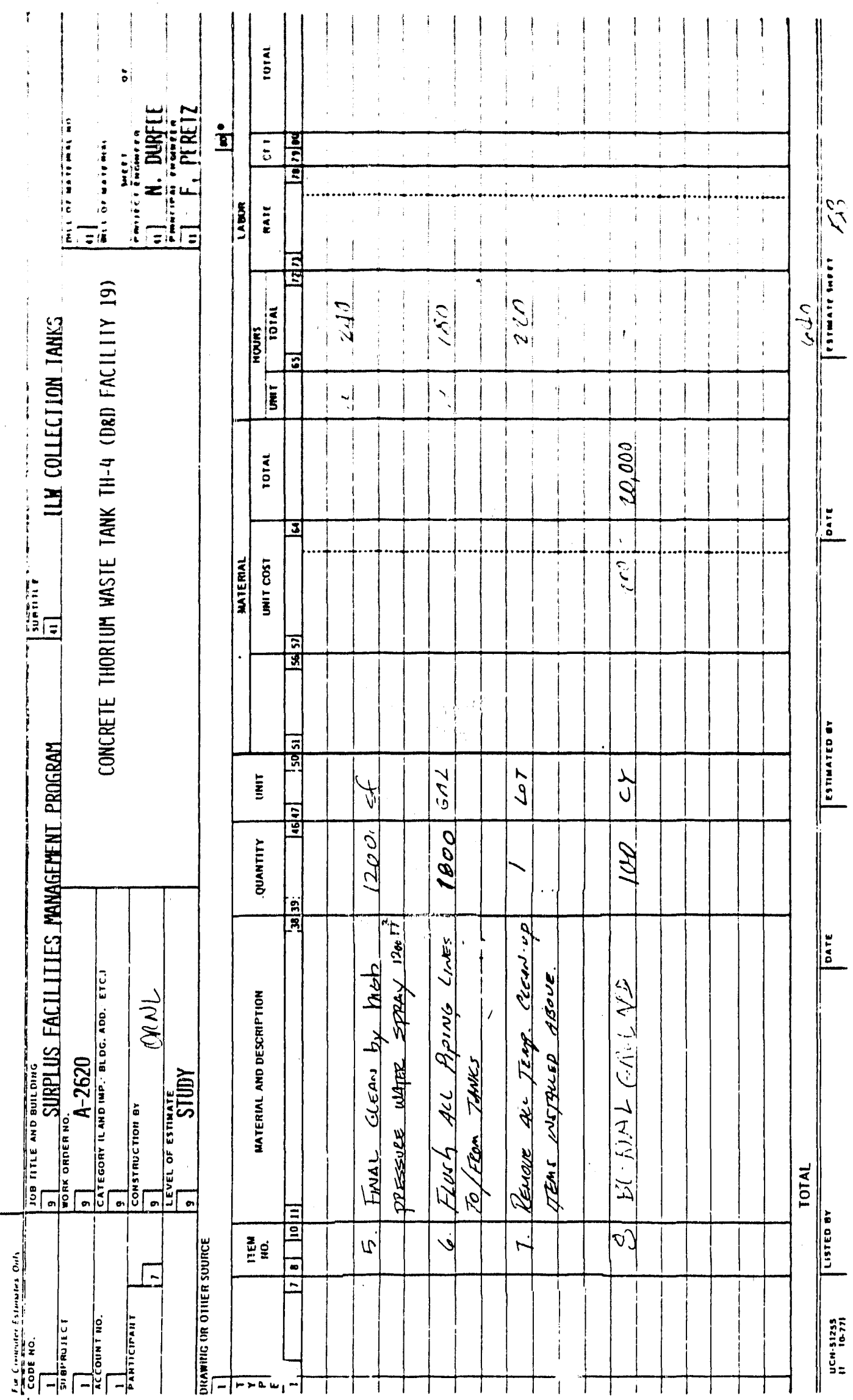




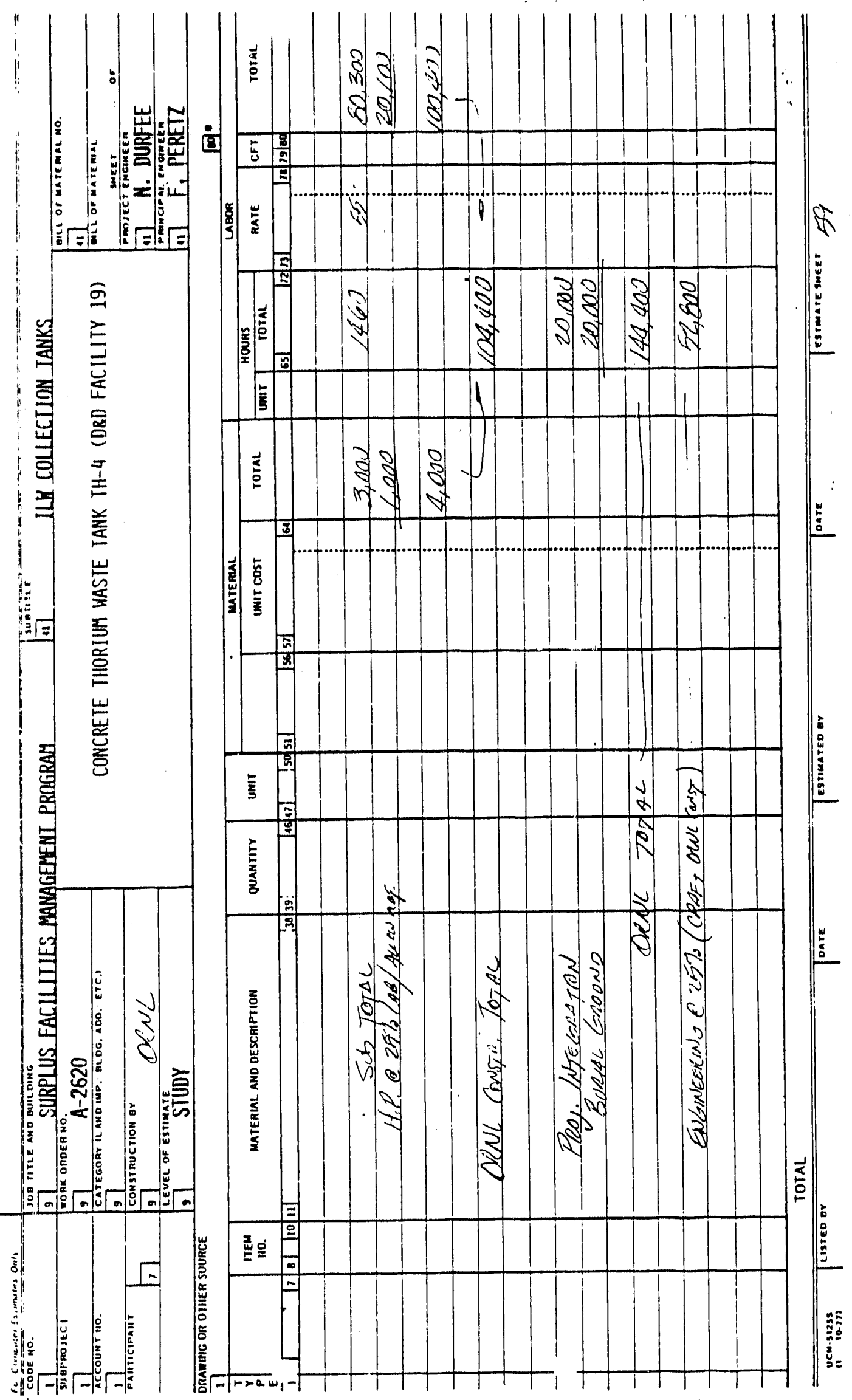




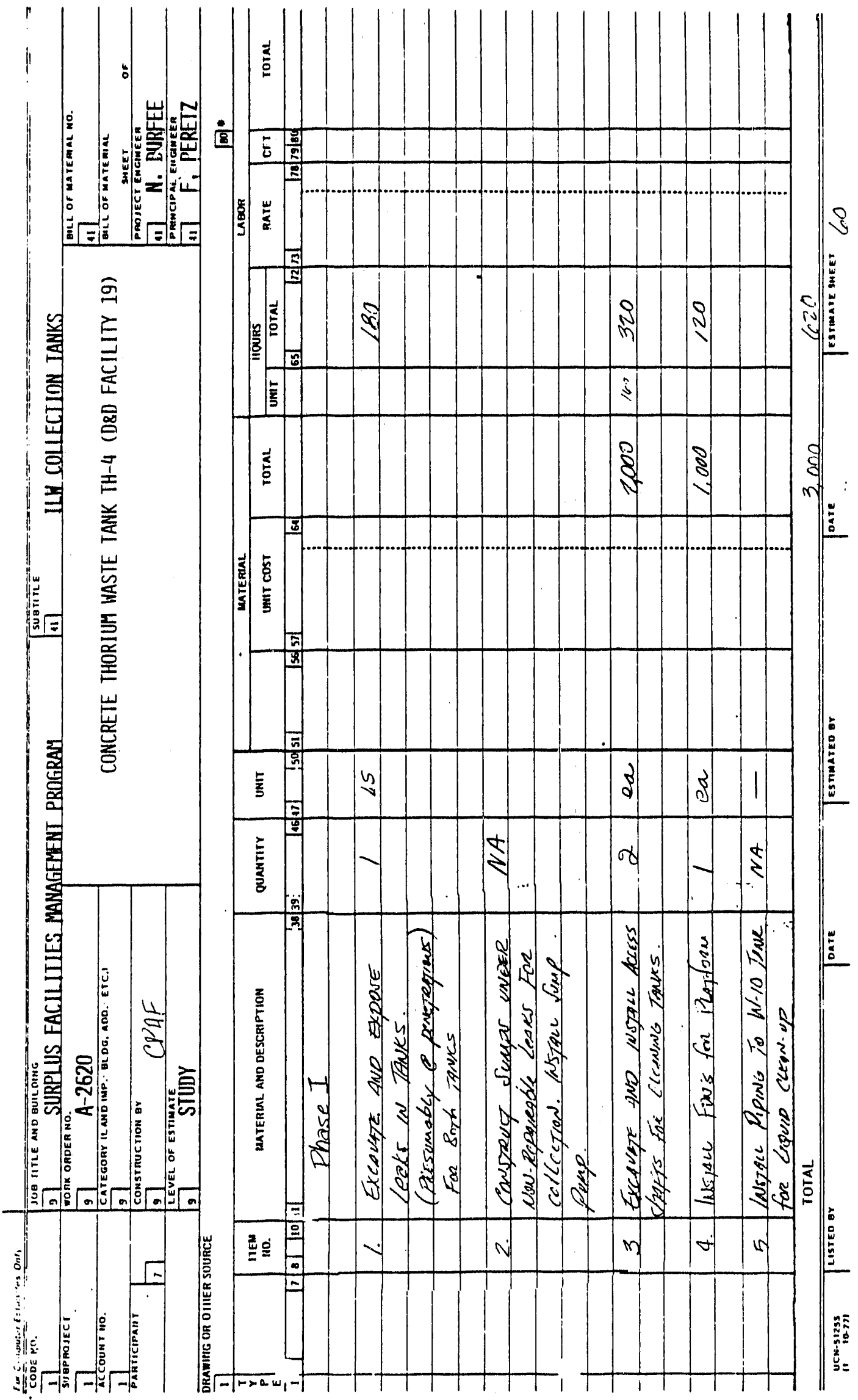




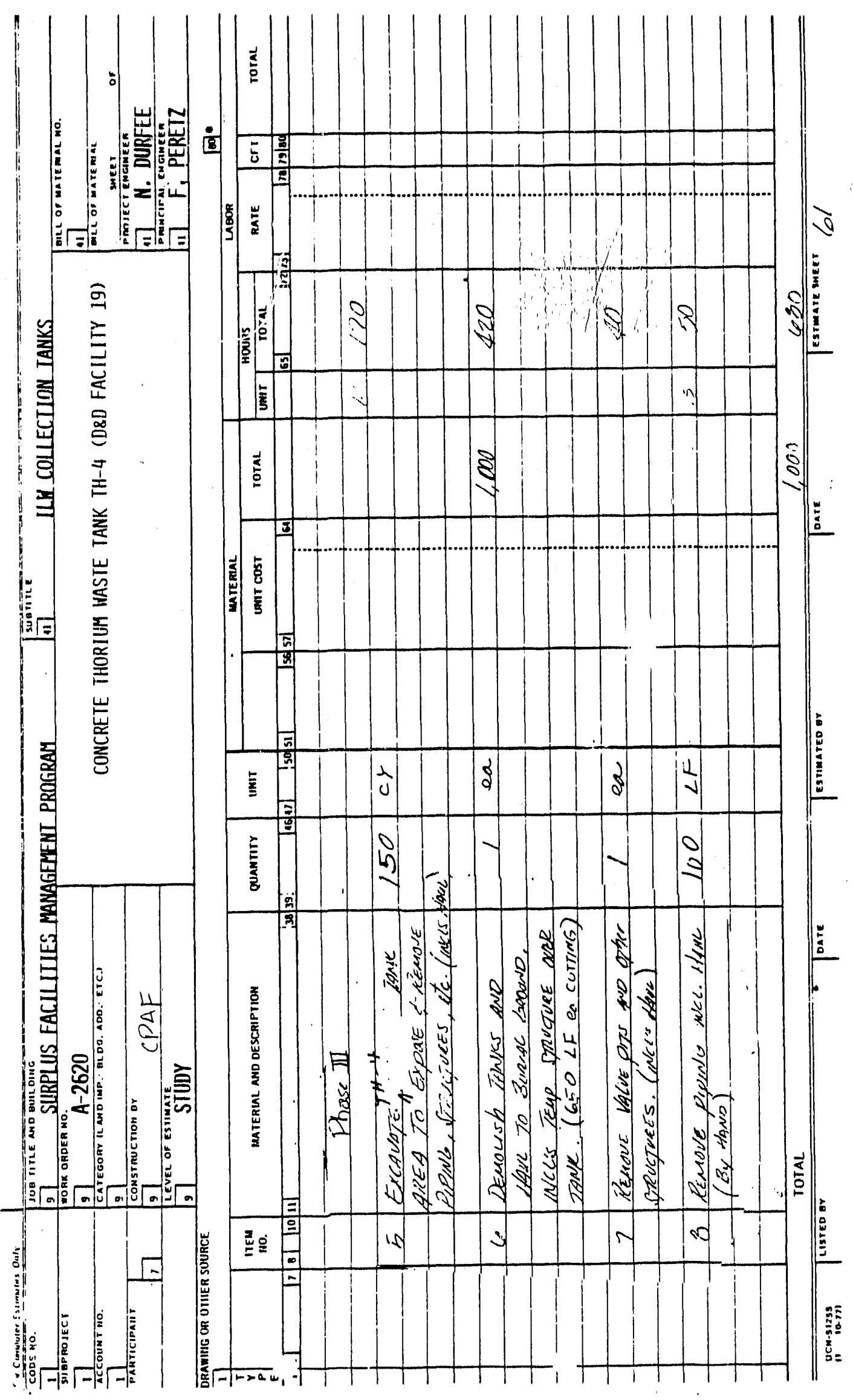




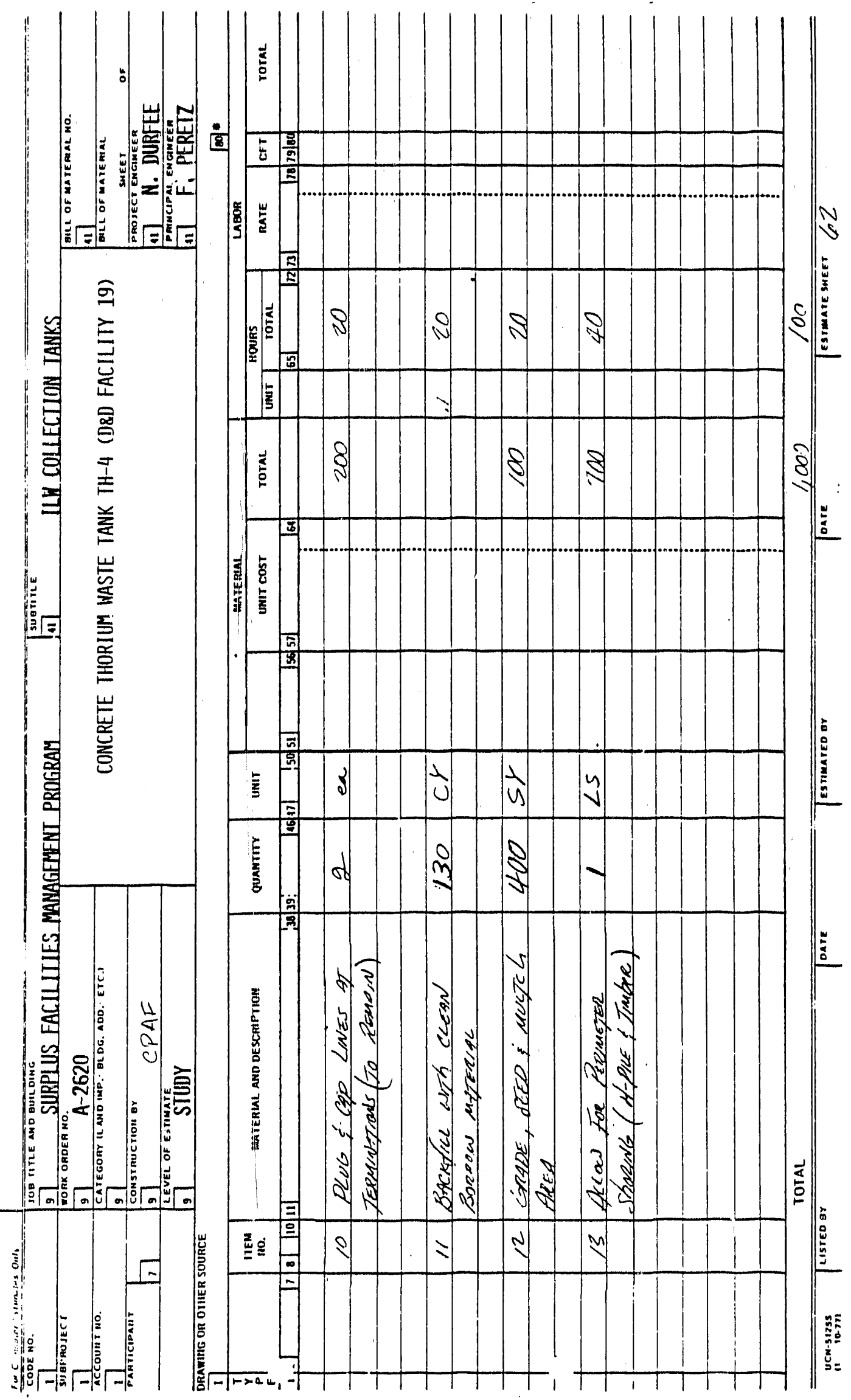




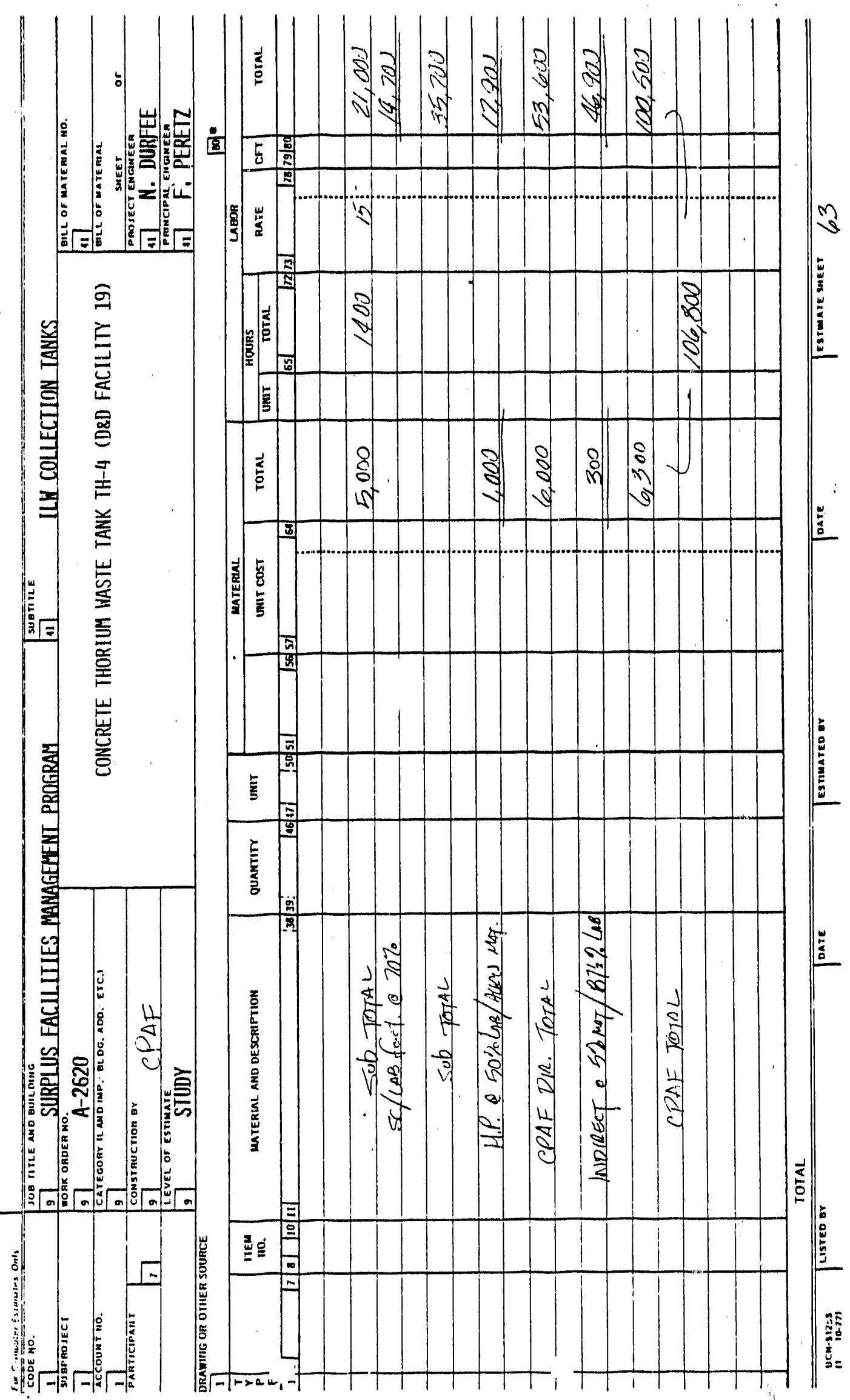




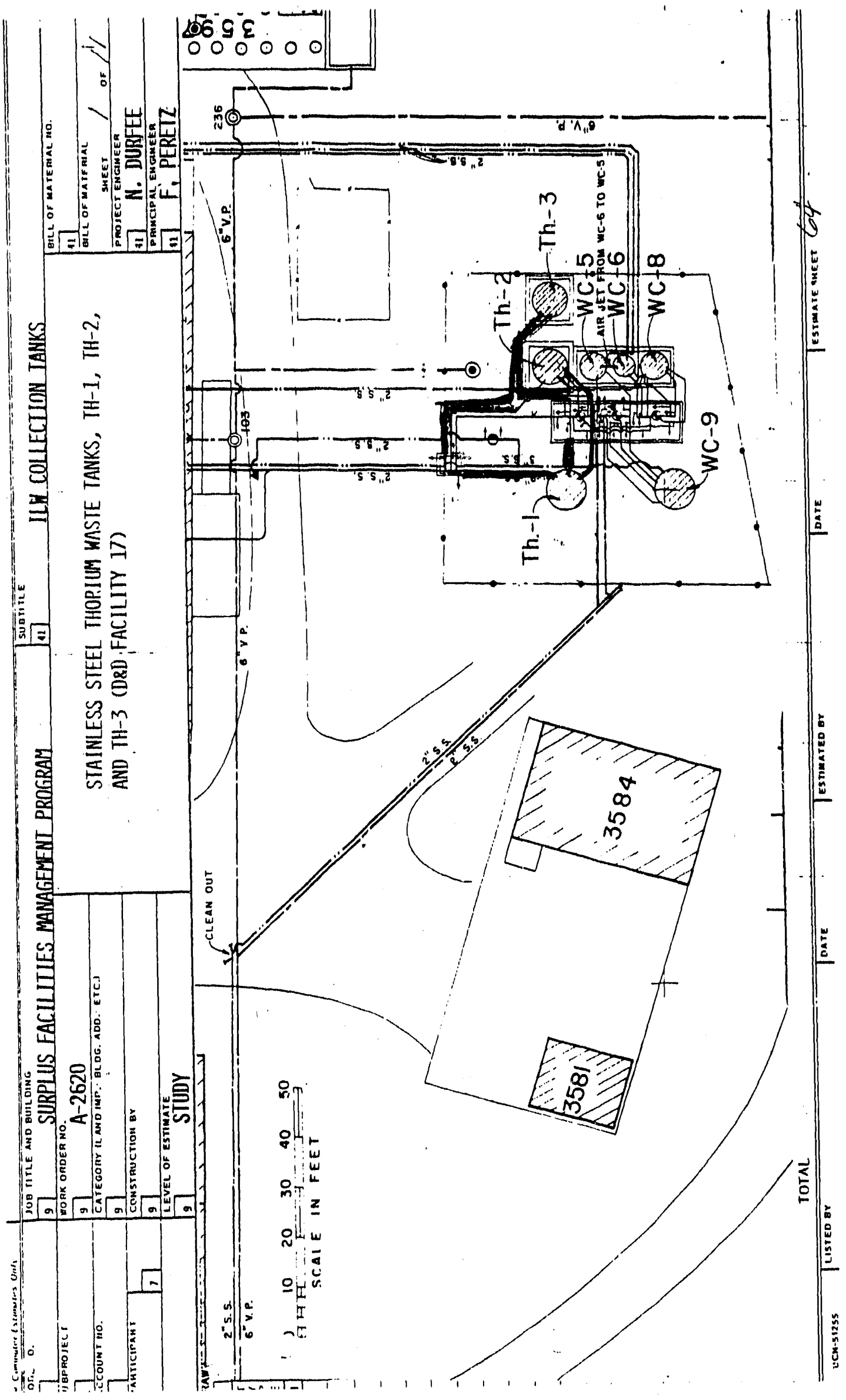




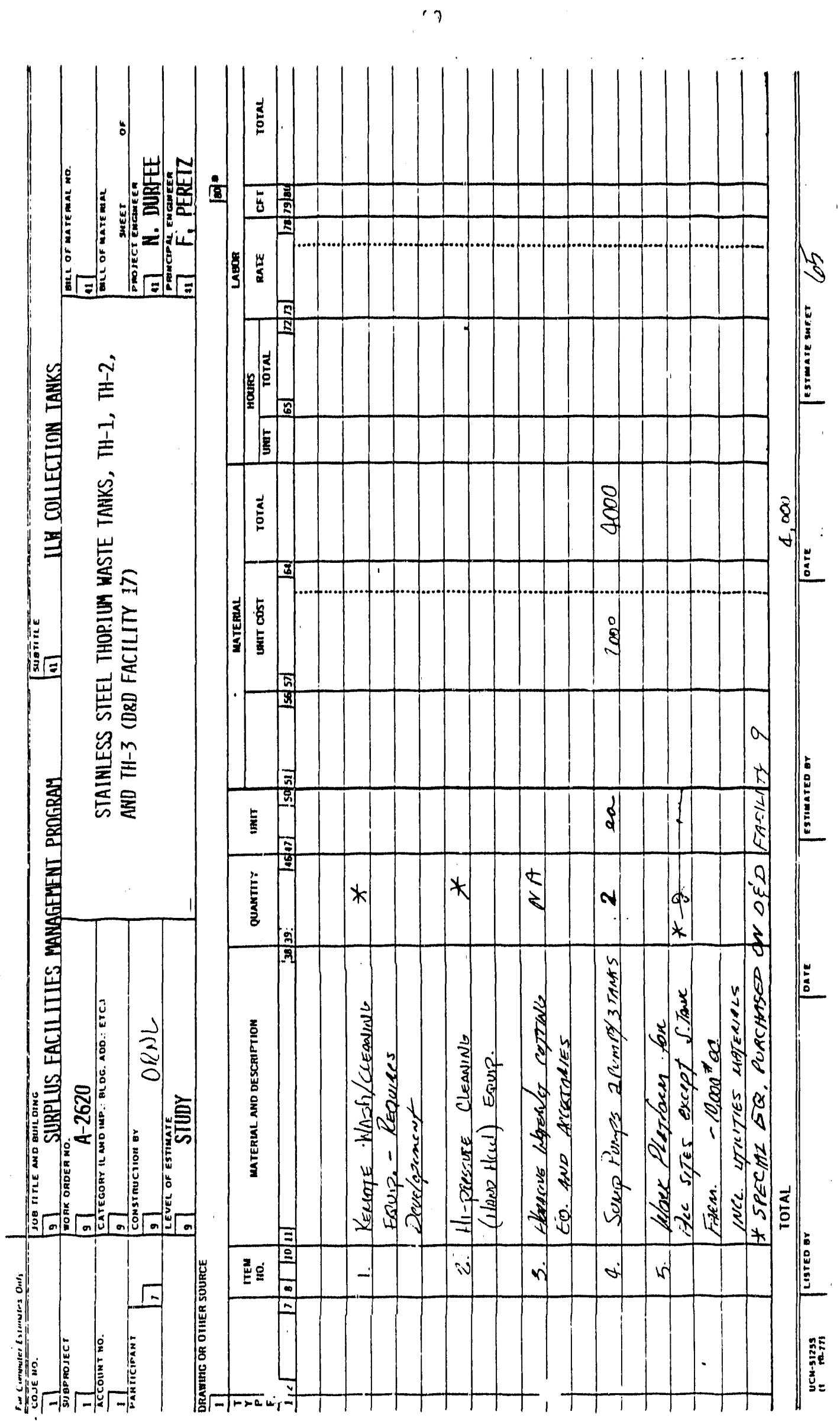




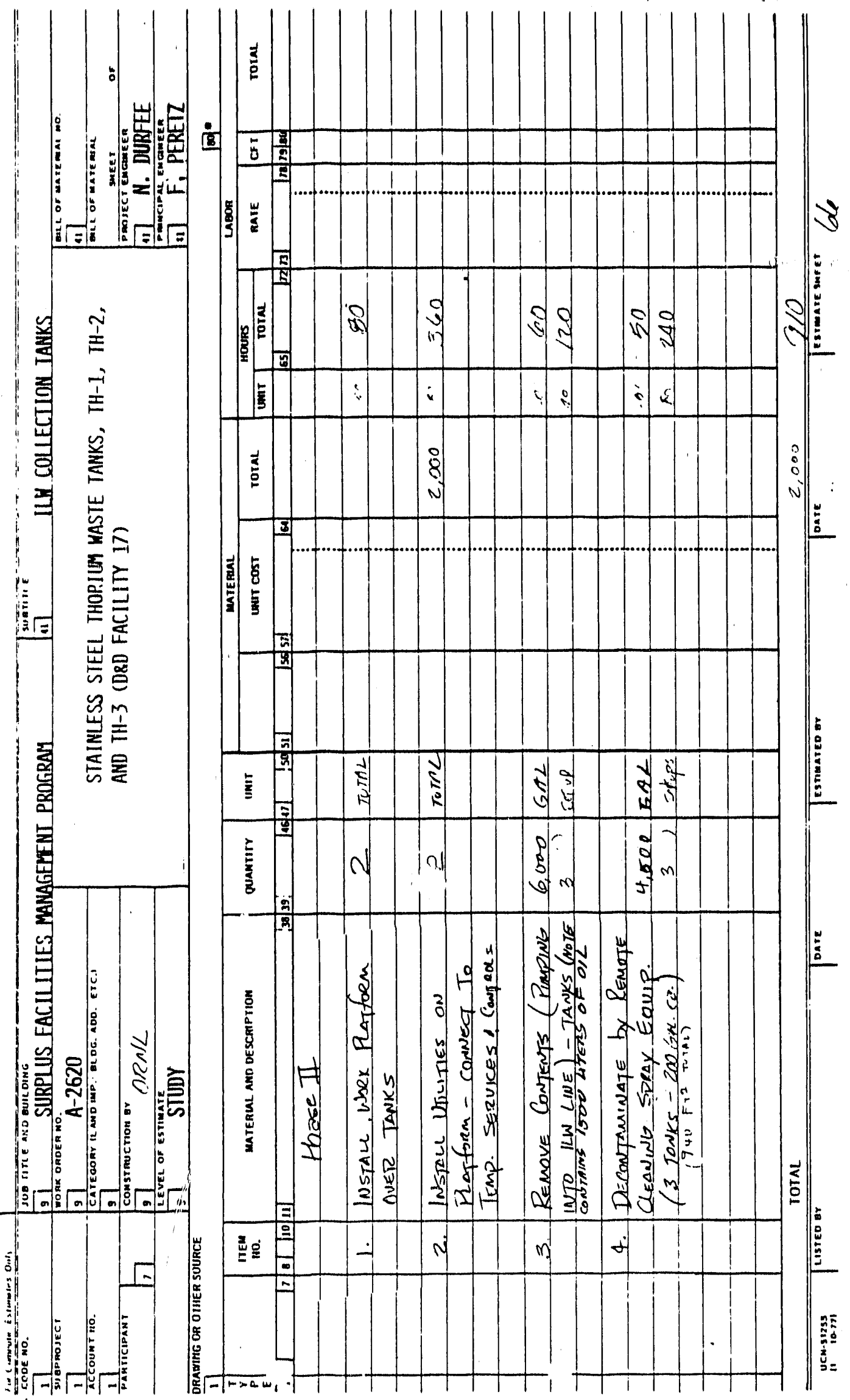


91

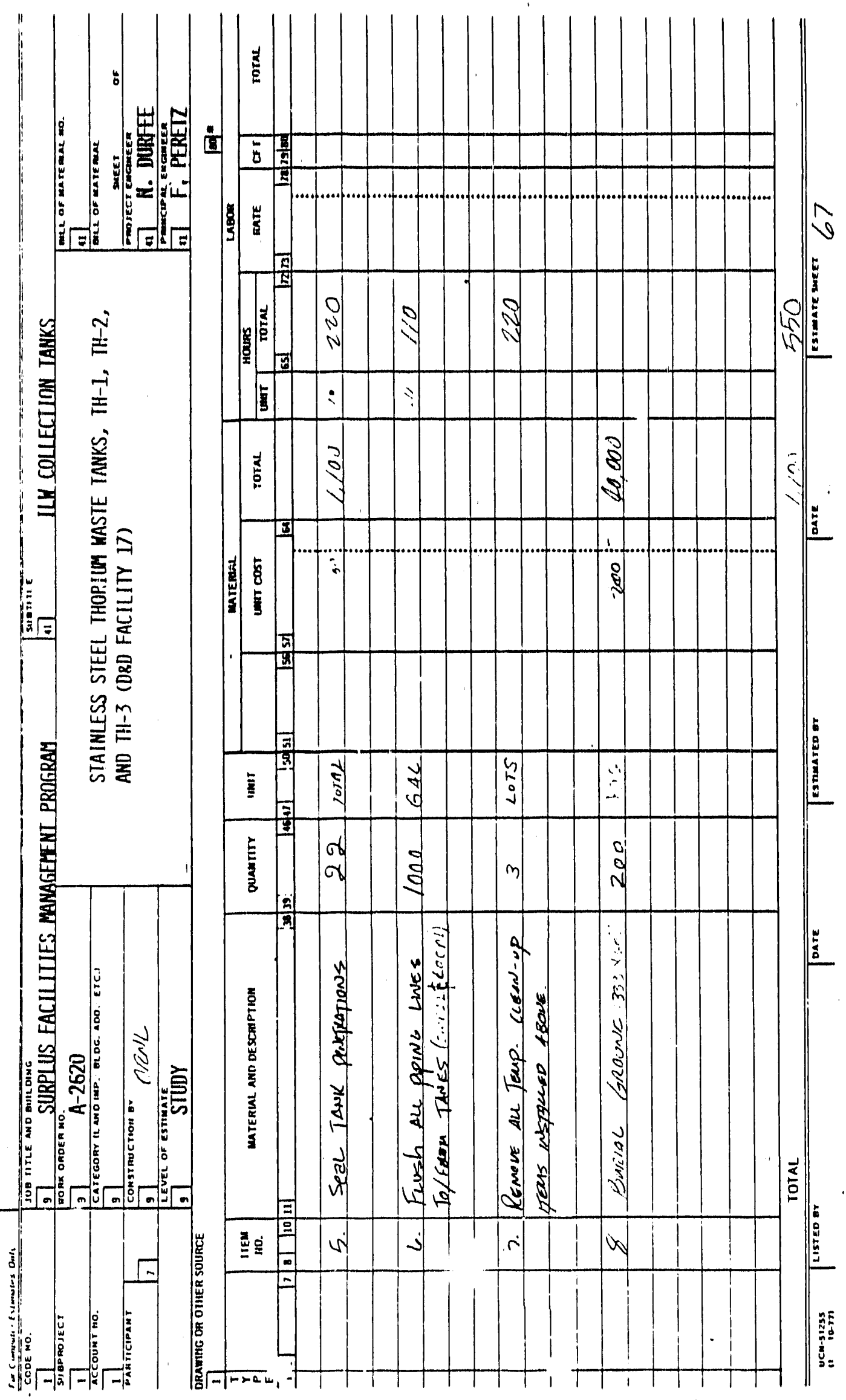




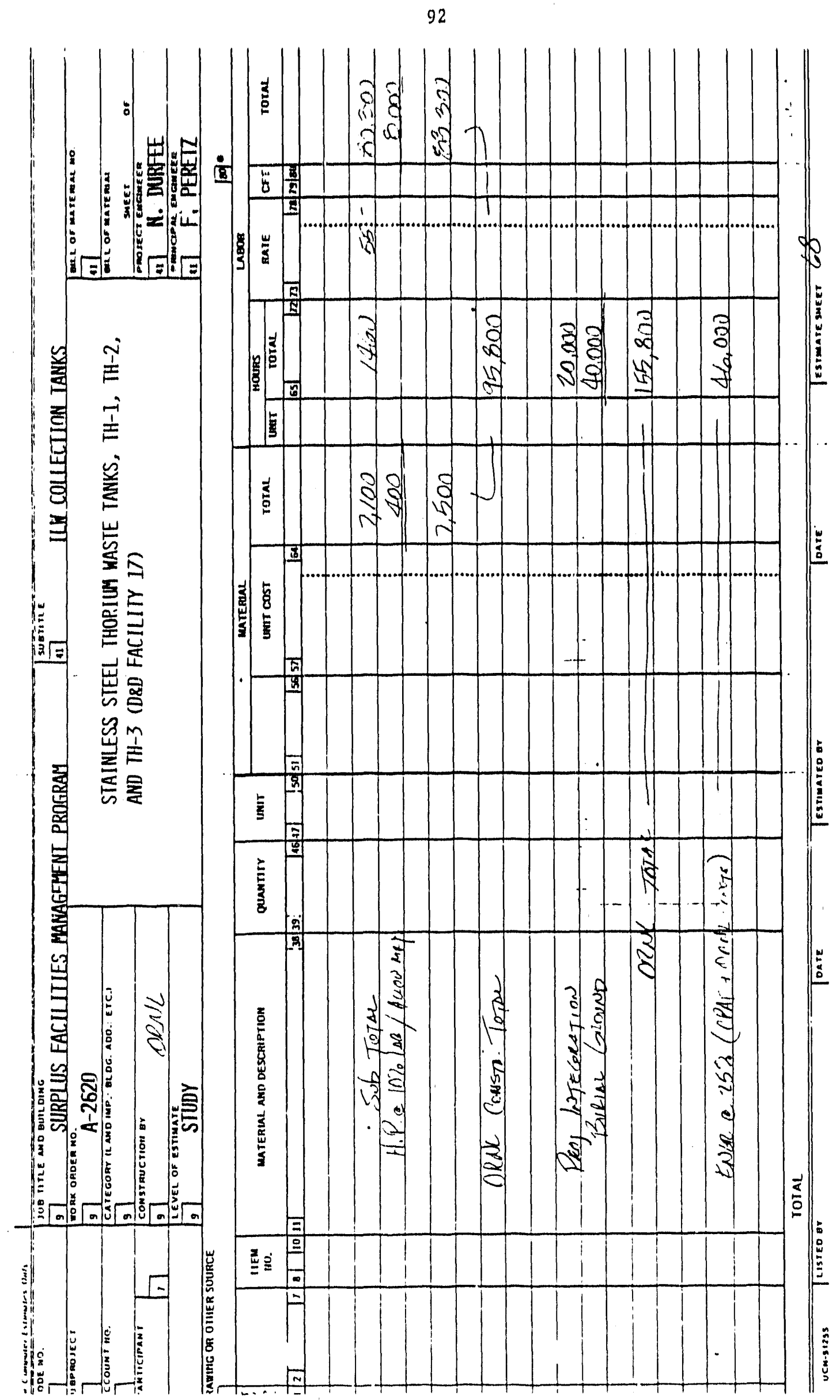




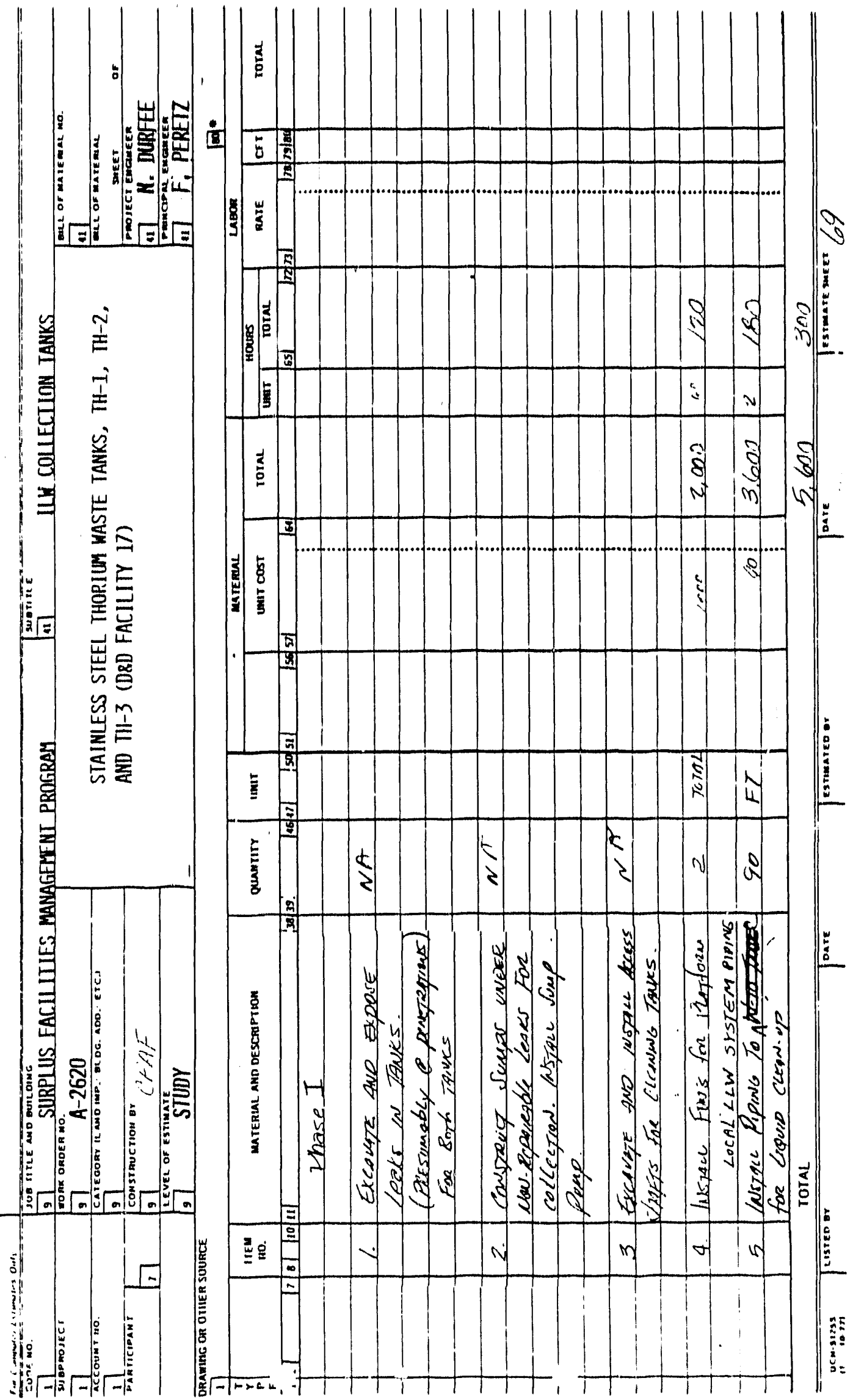




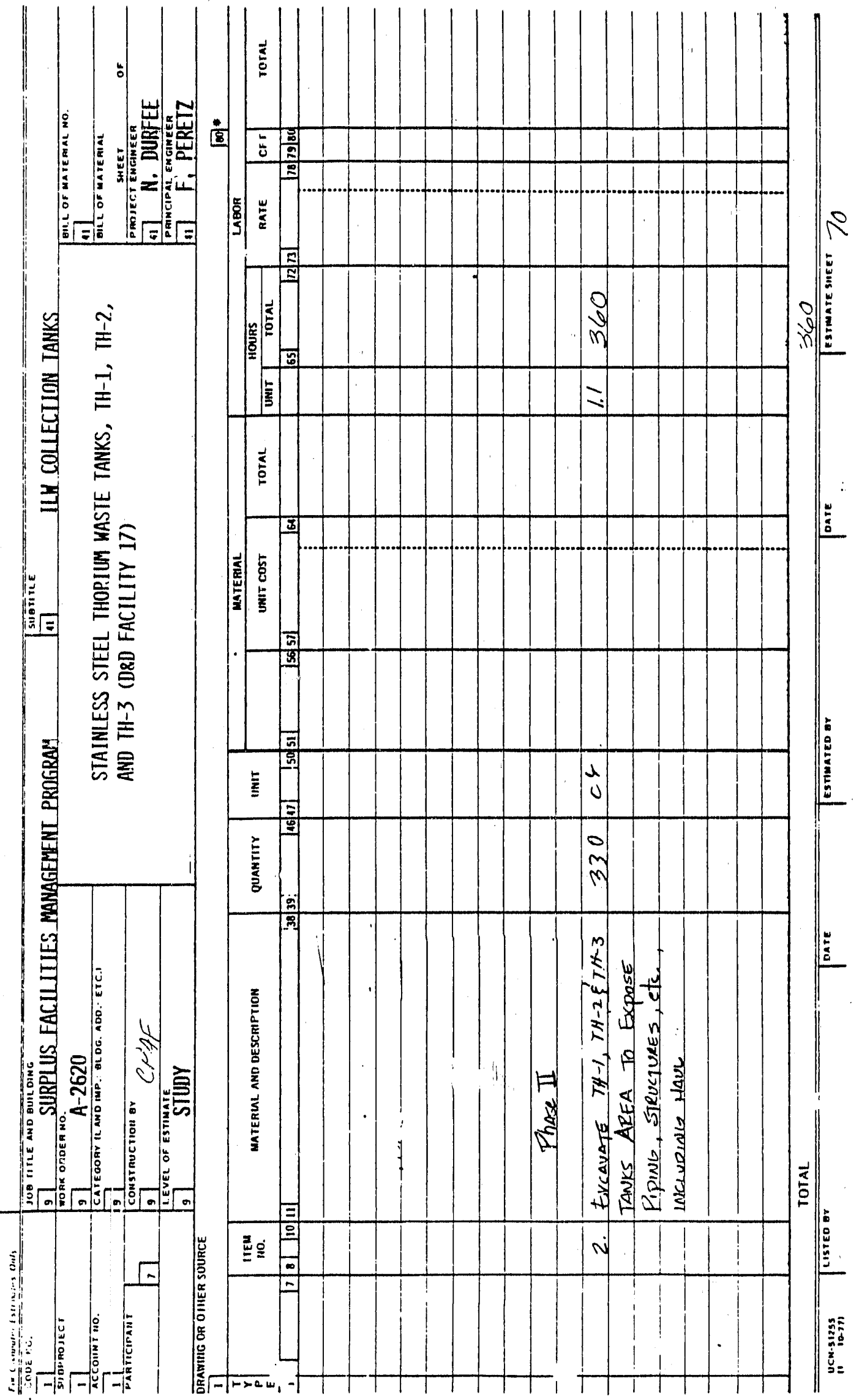




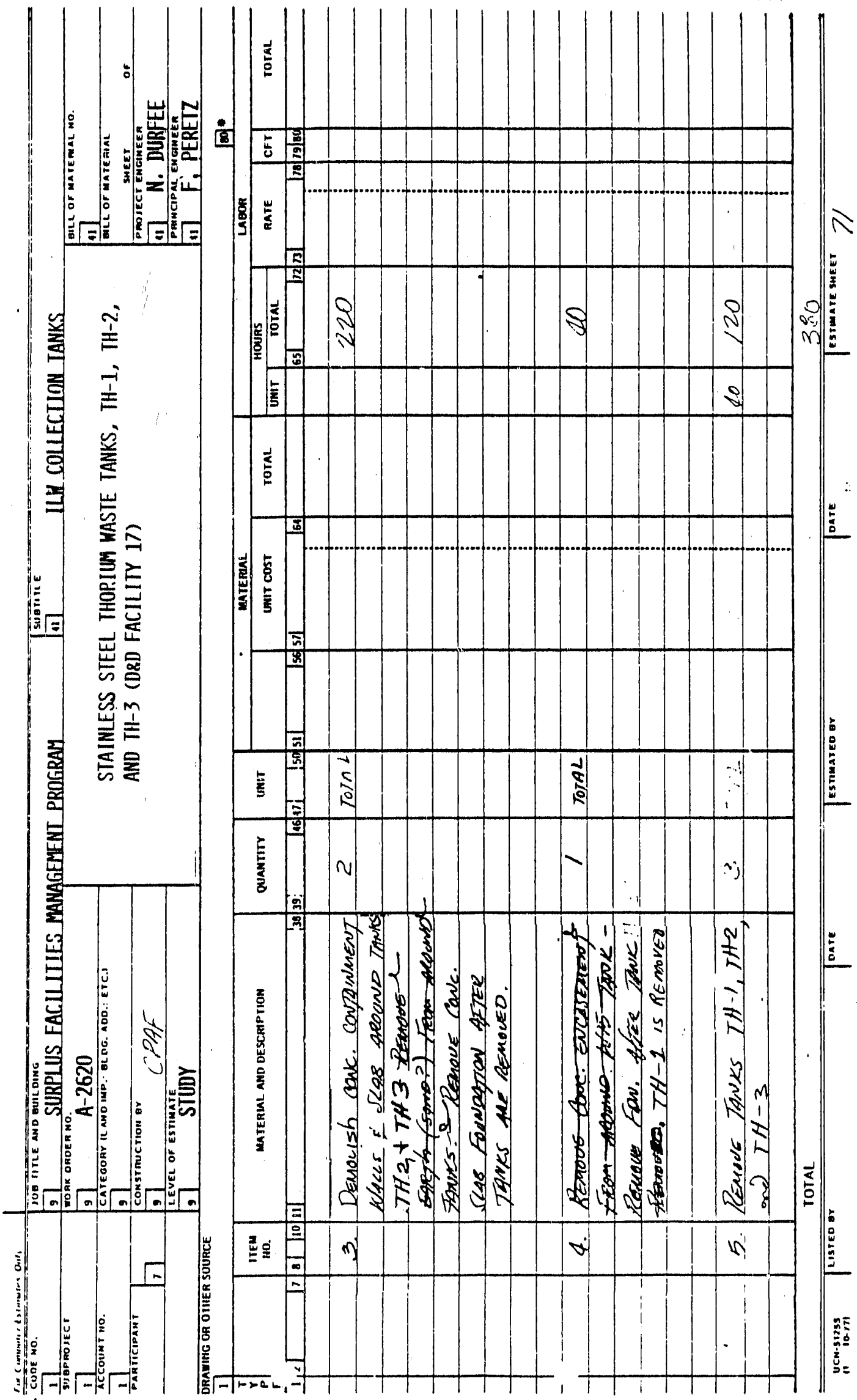




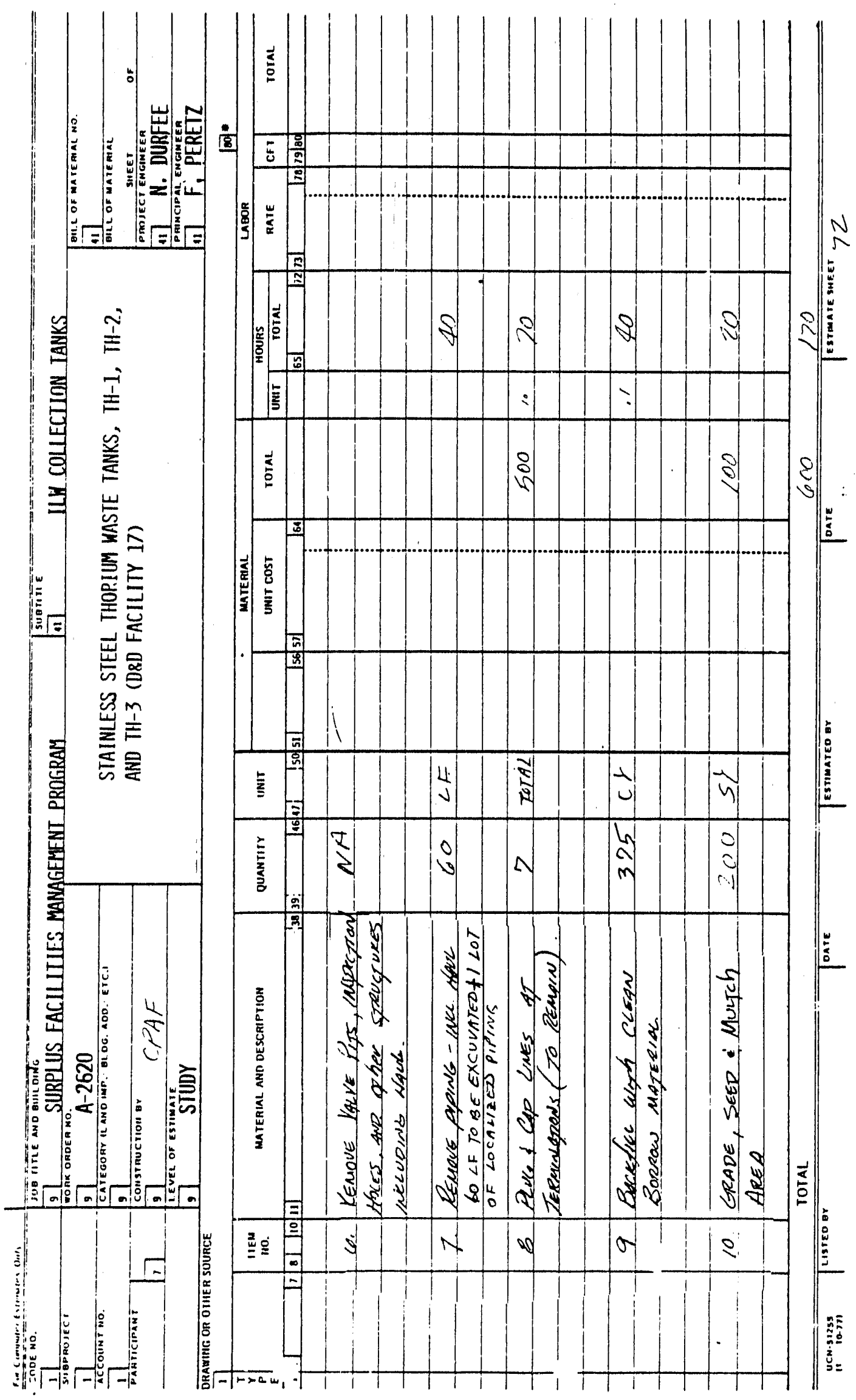




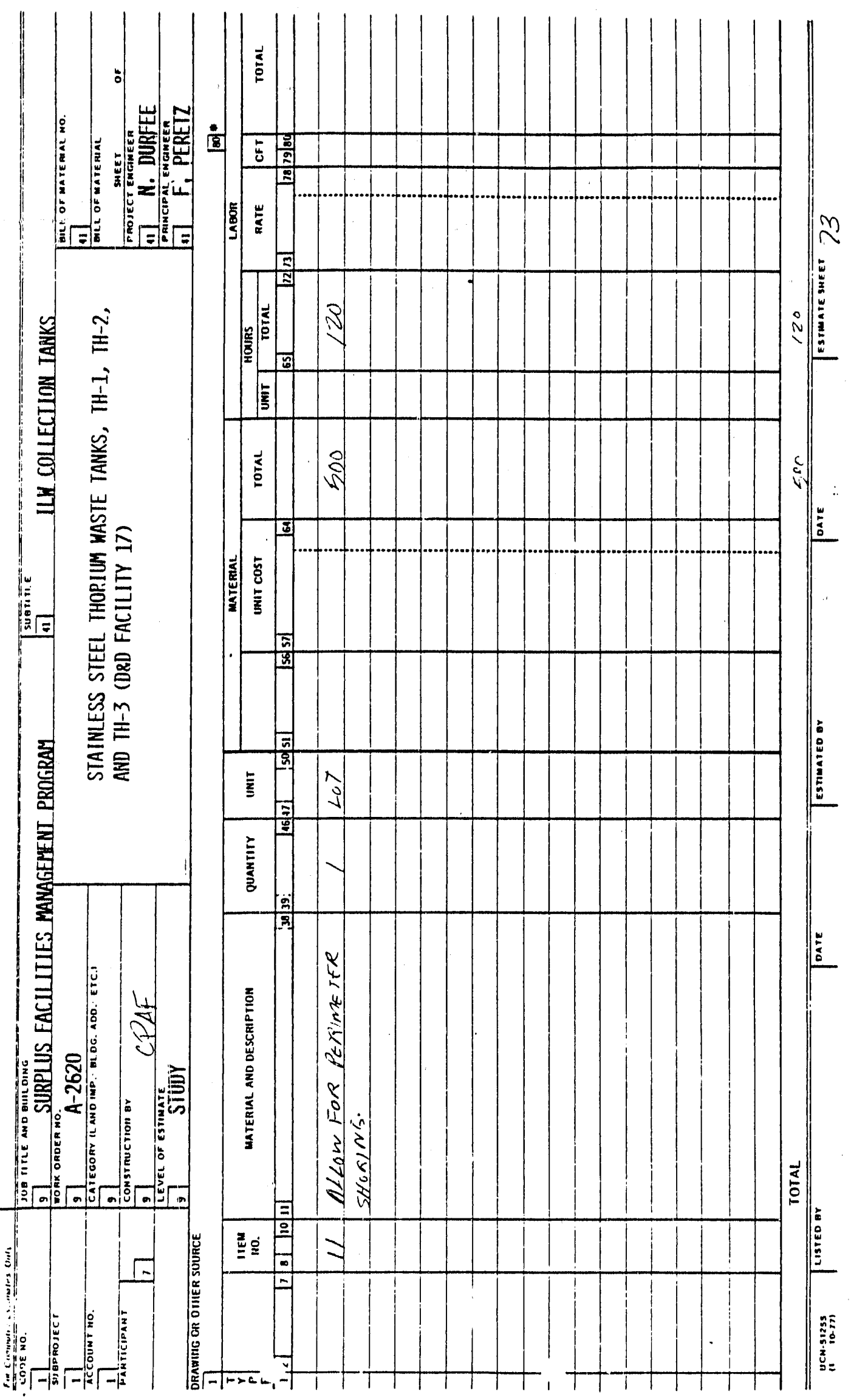




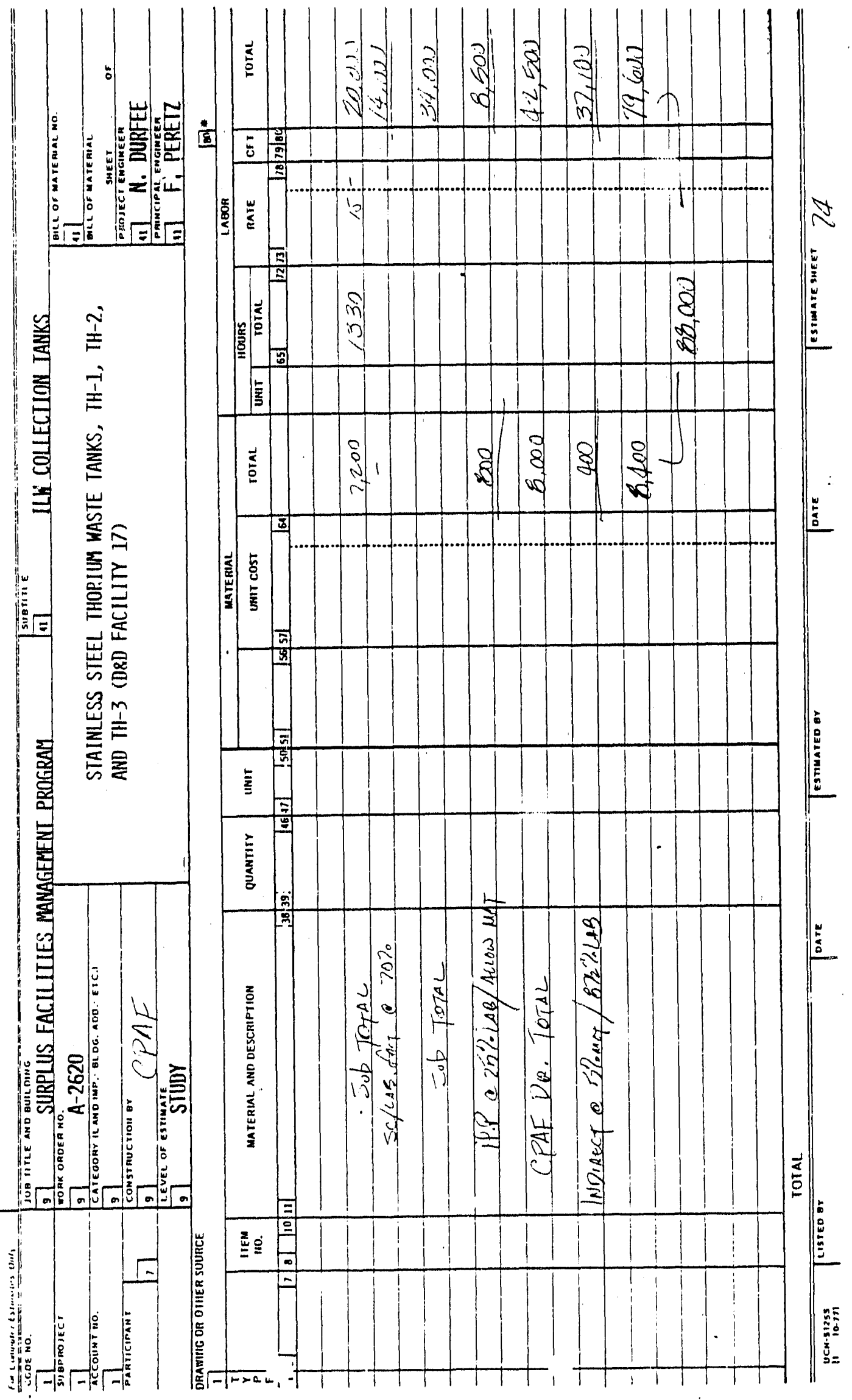




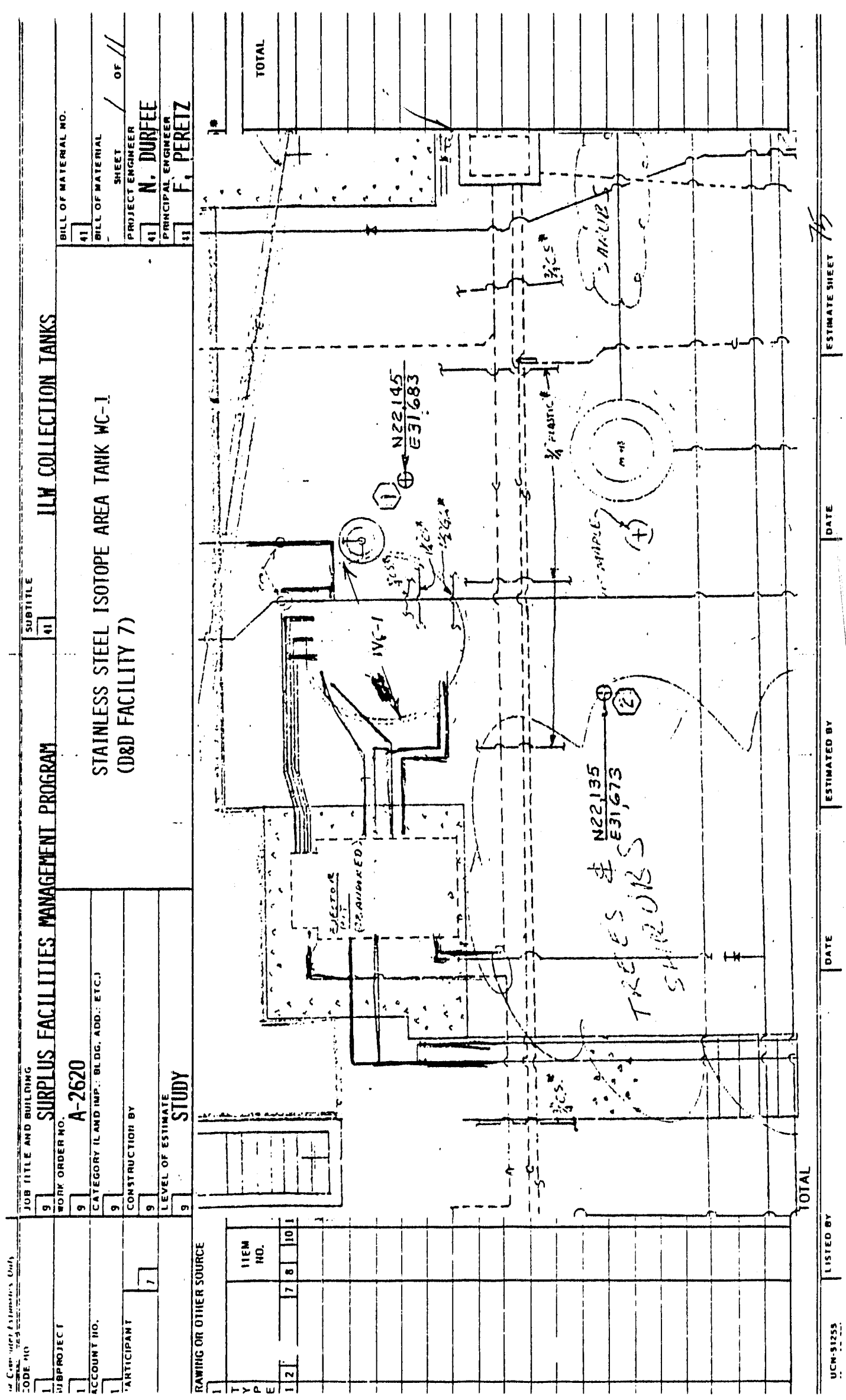


100

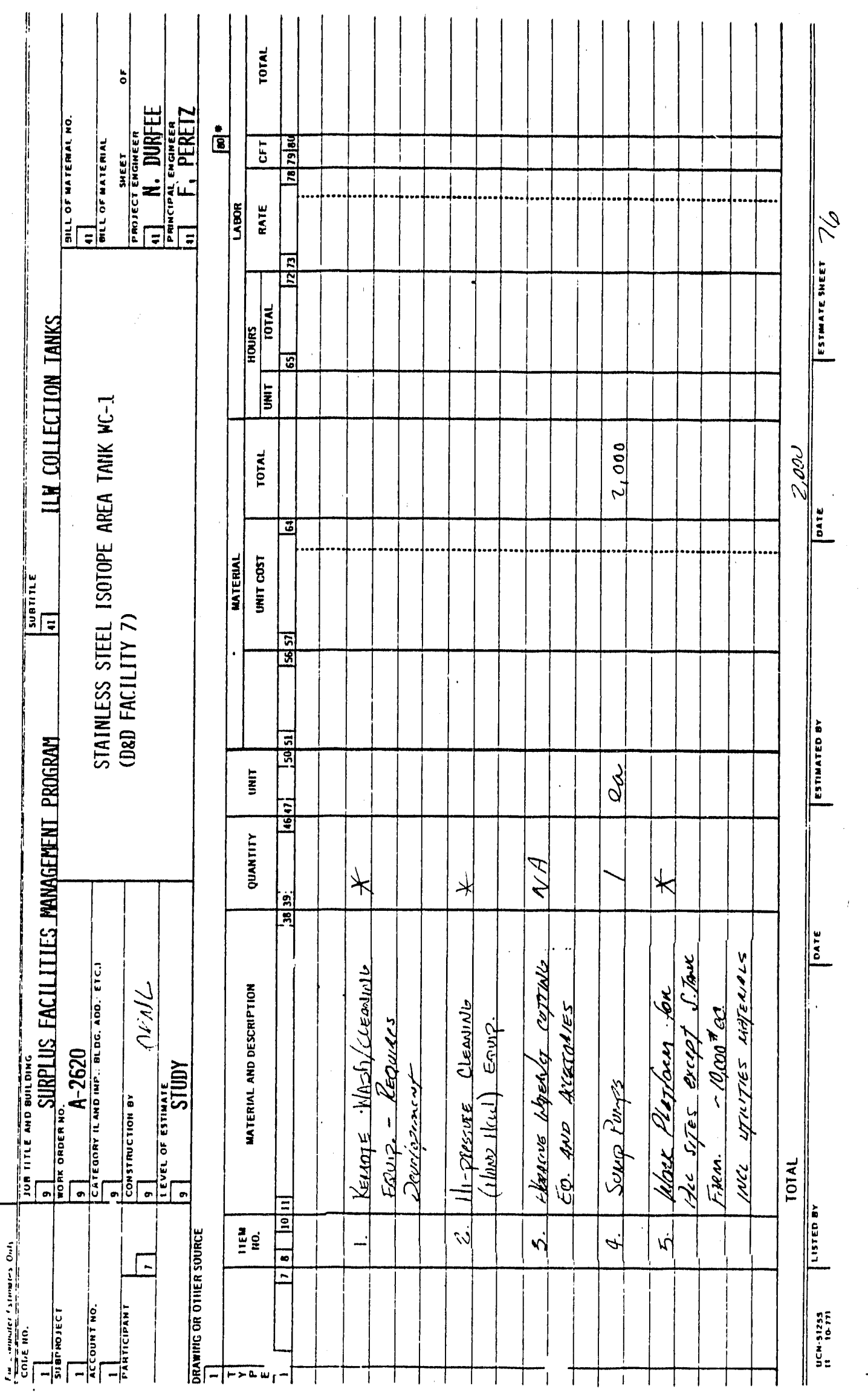


101

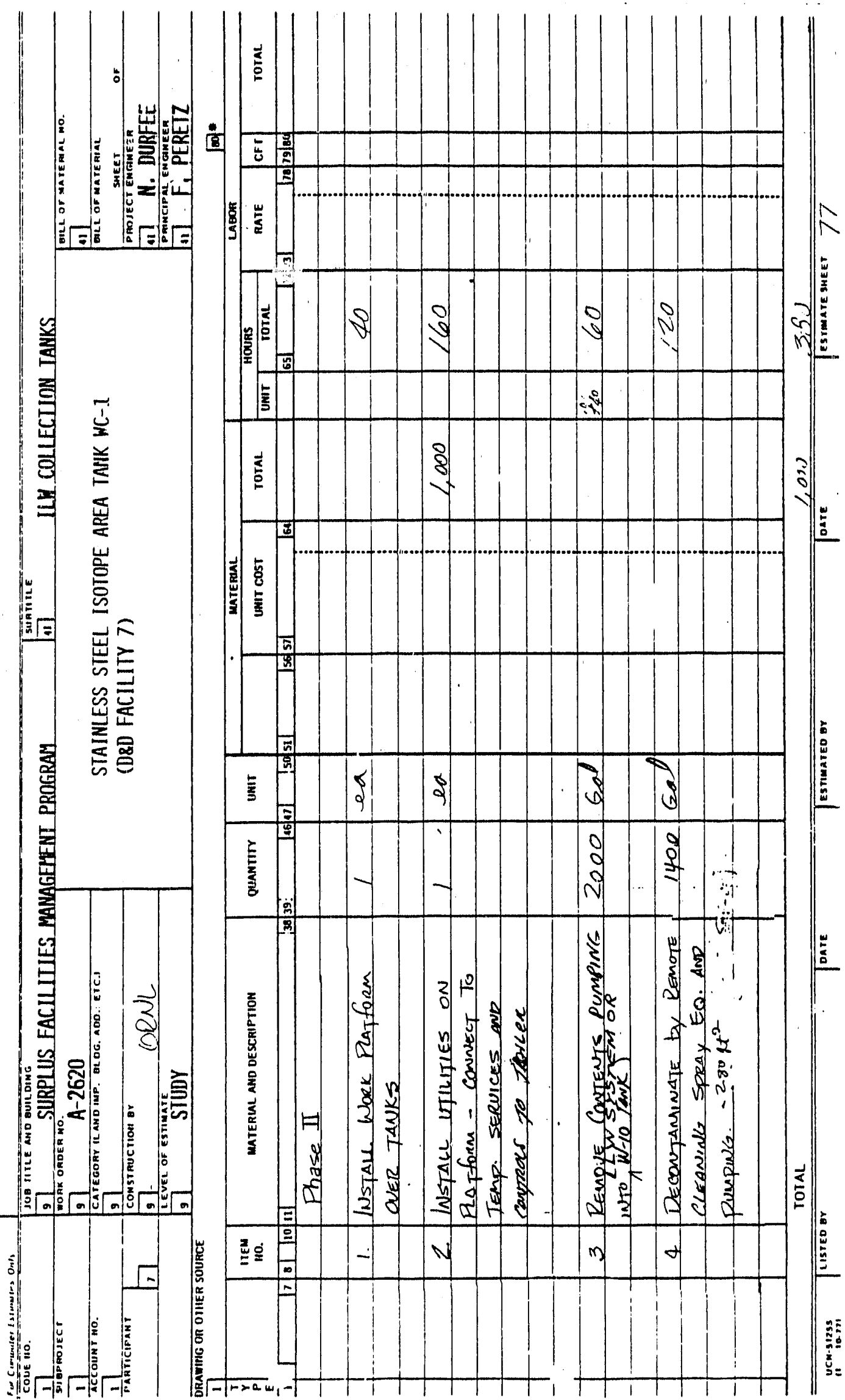


102

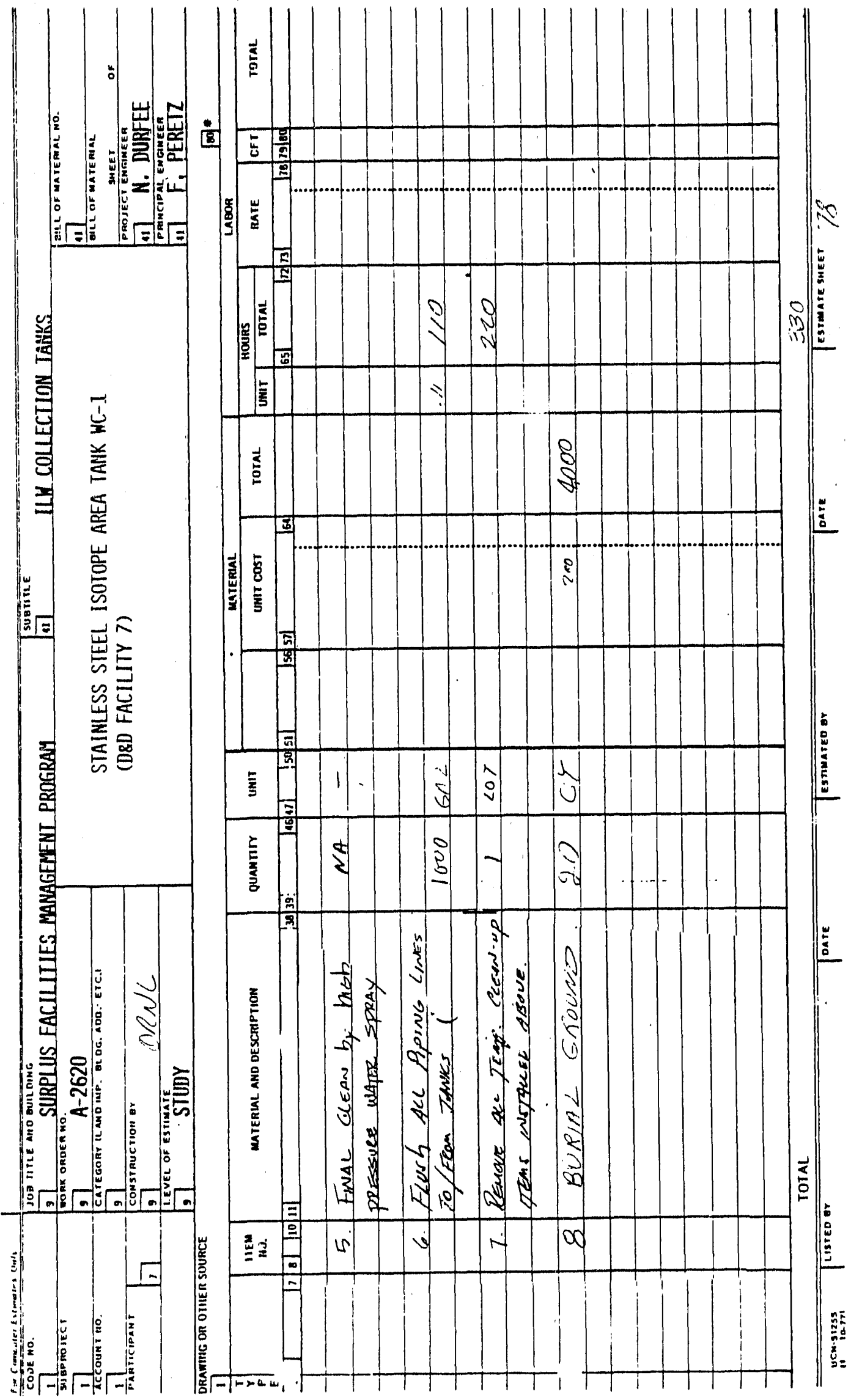




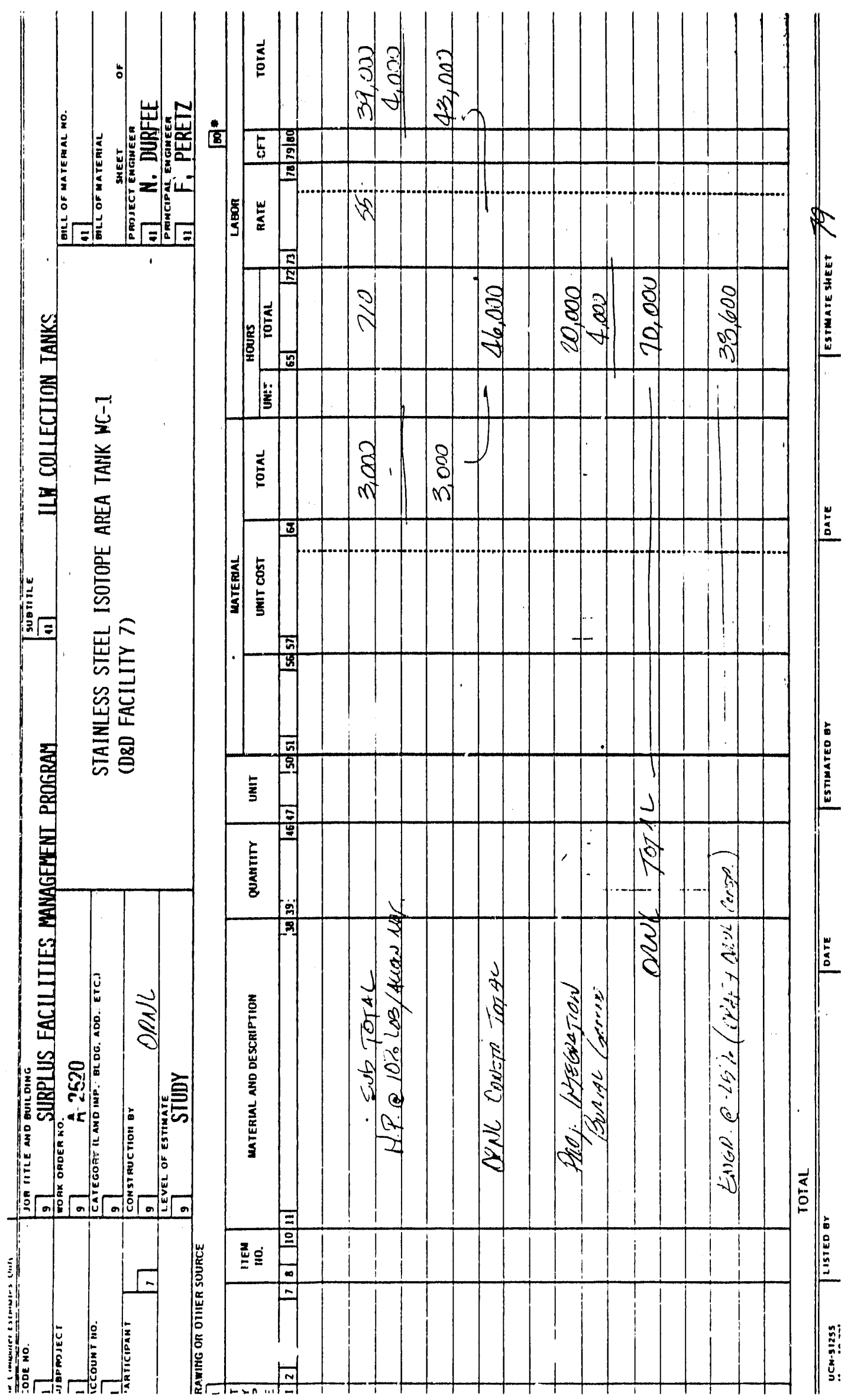


104

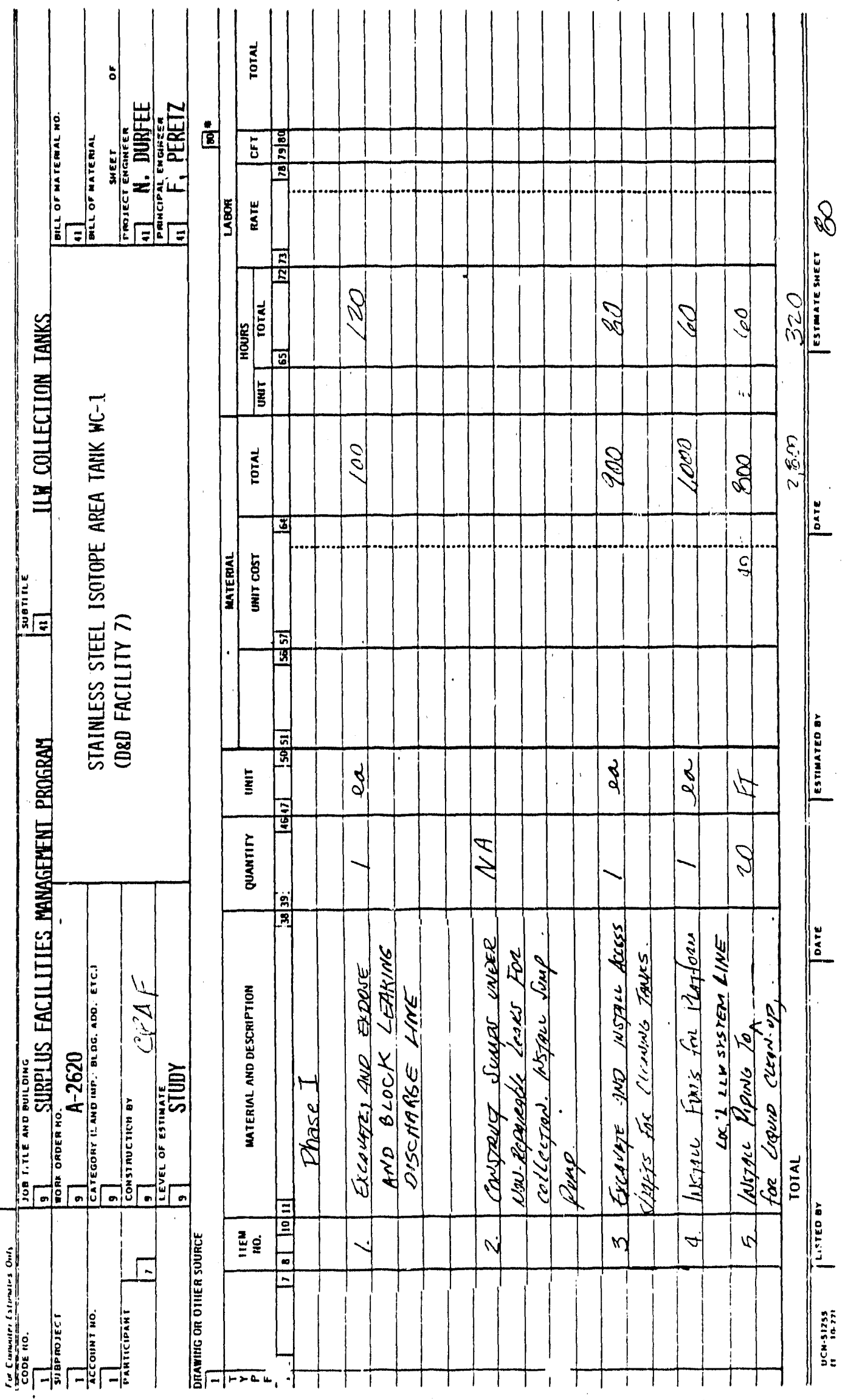


105

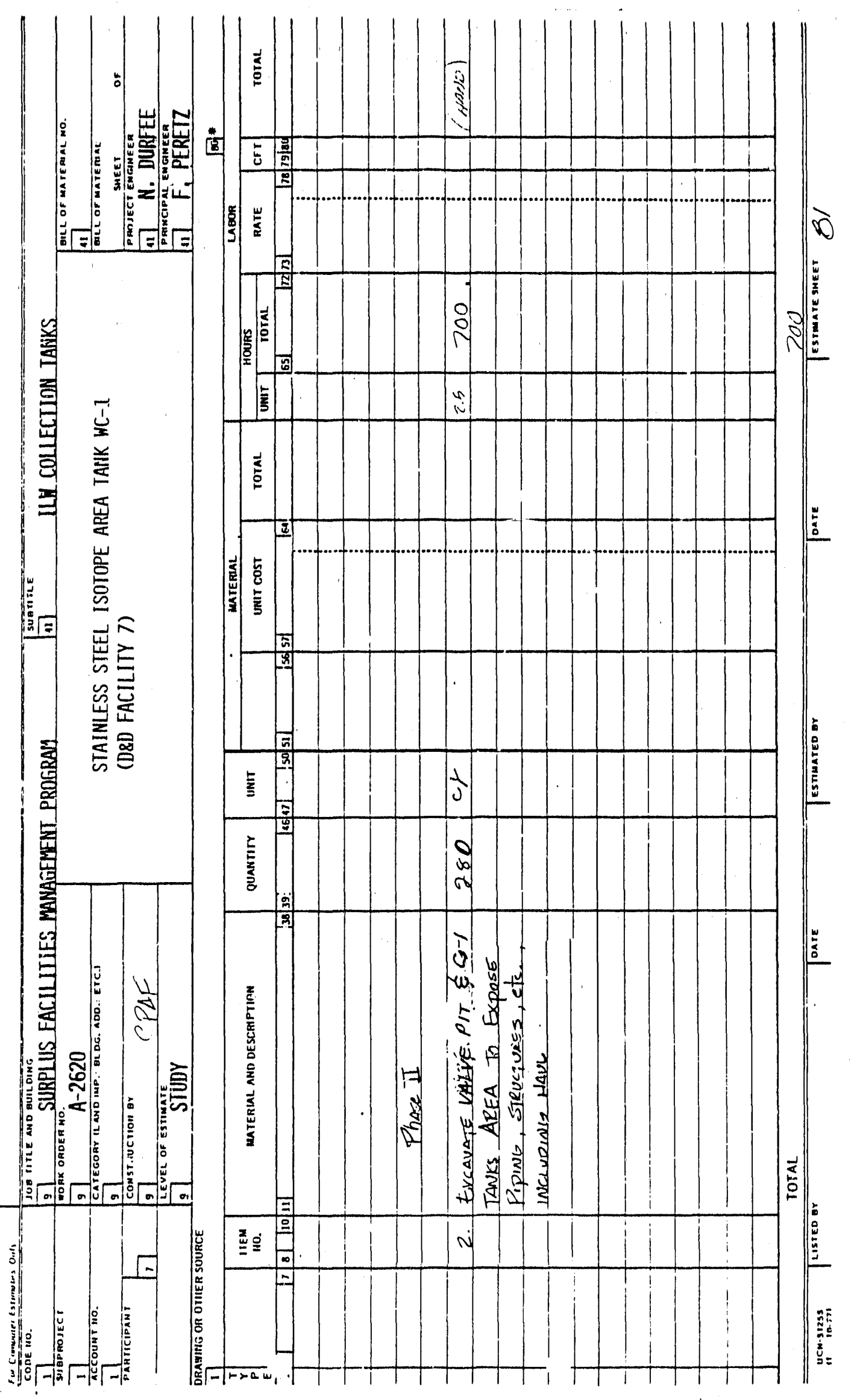




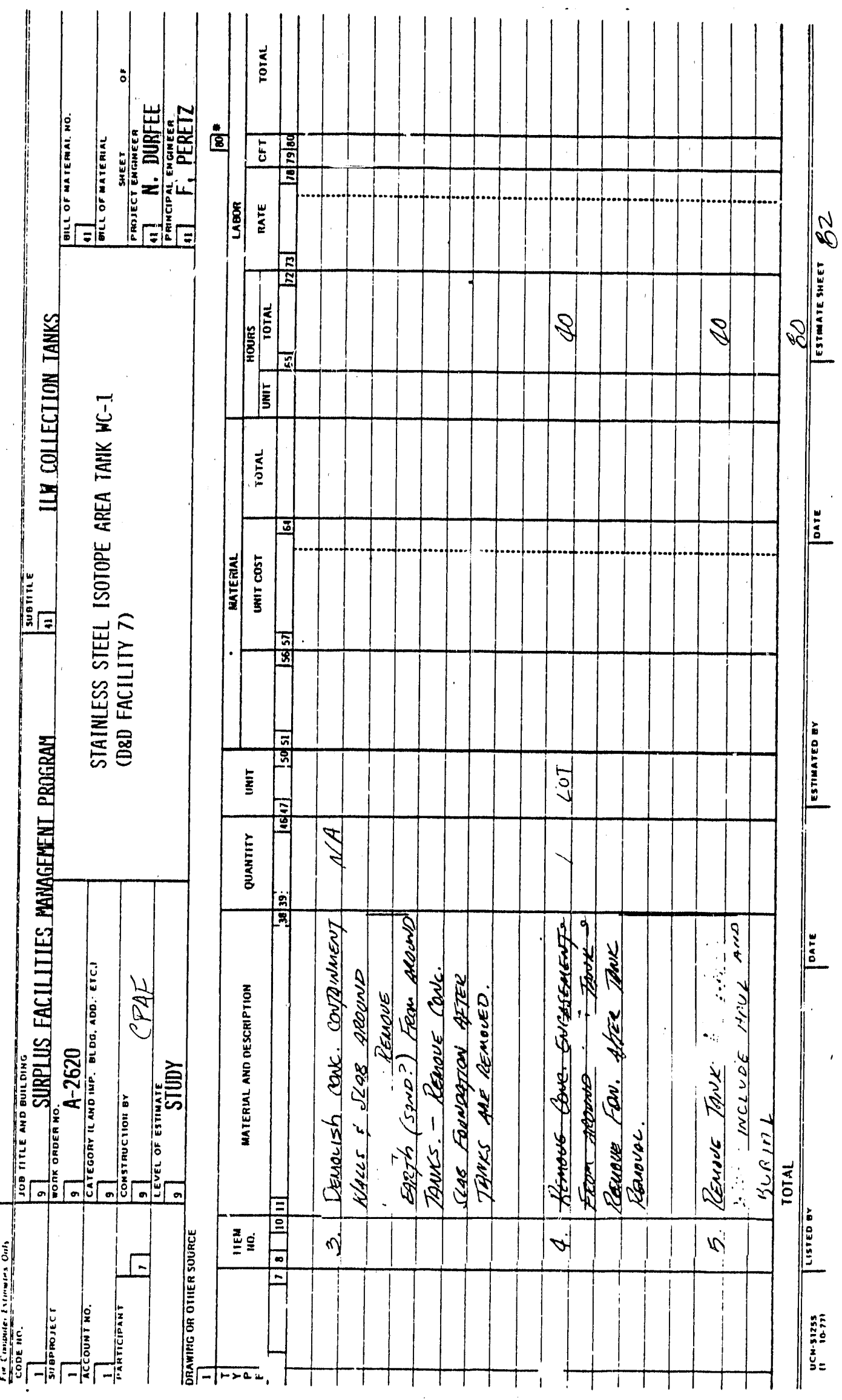




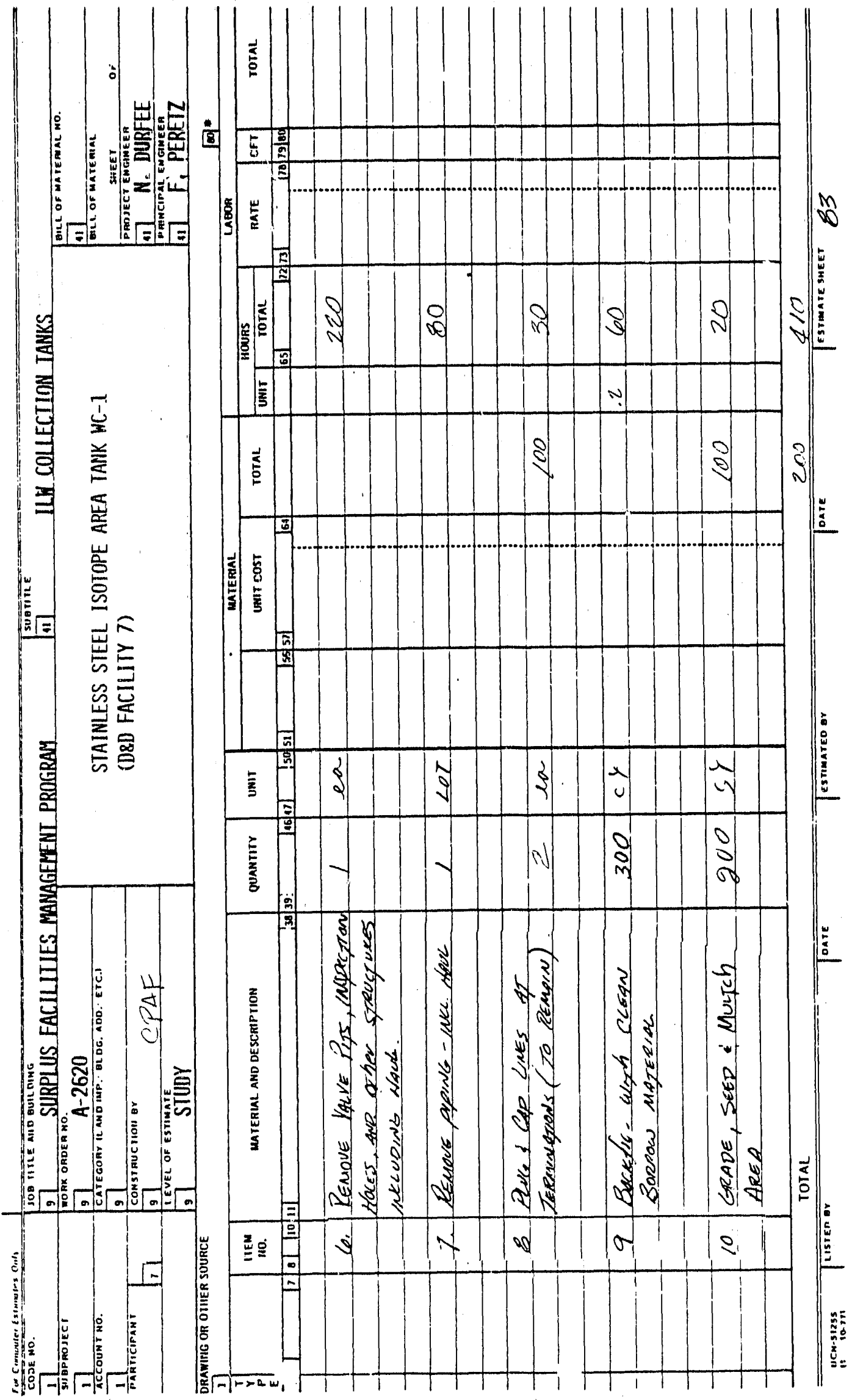




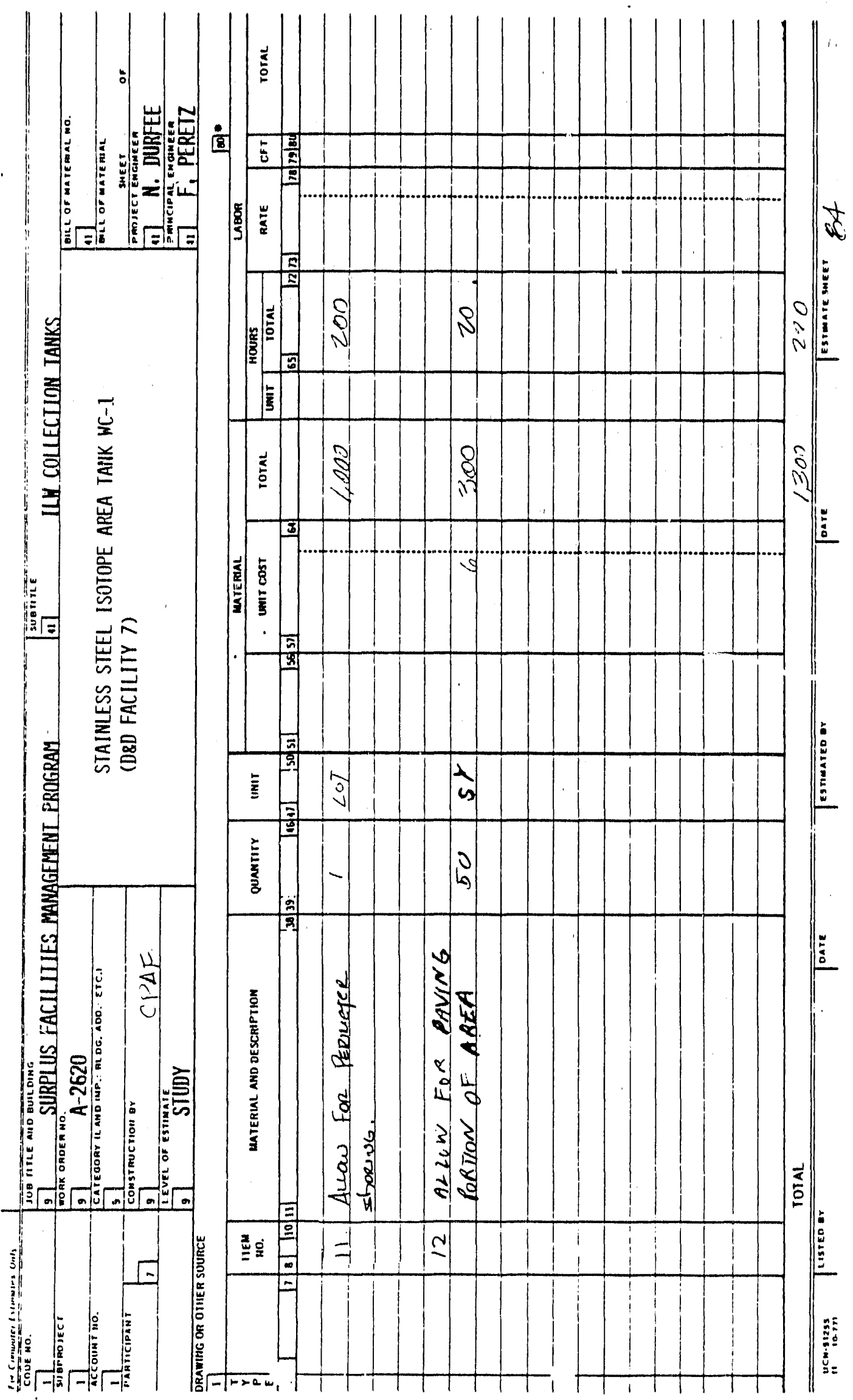


109

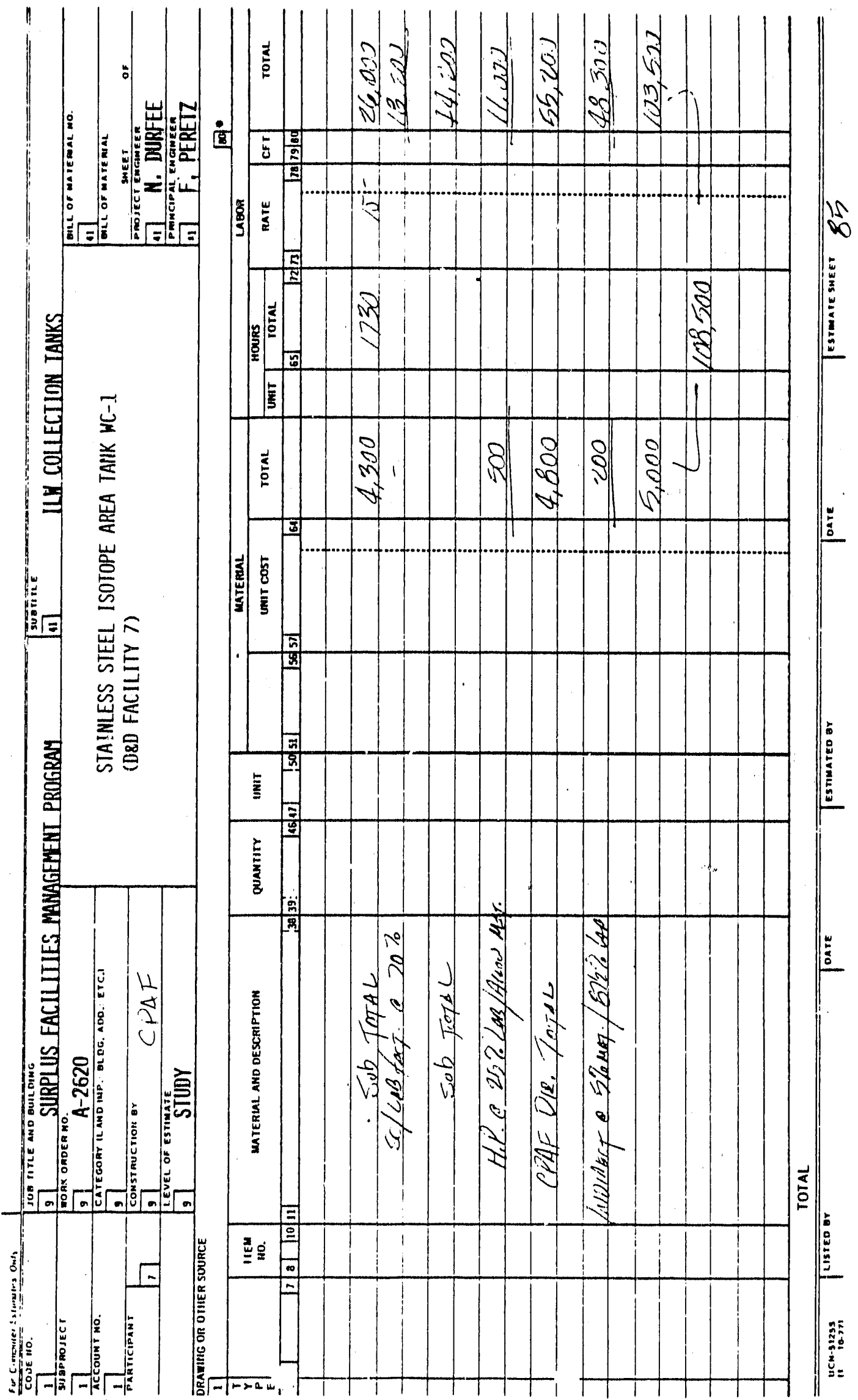




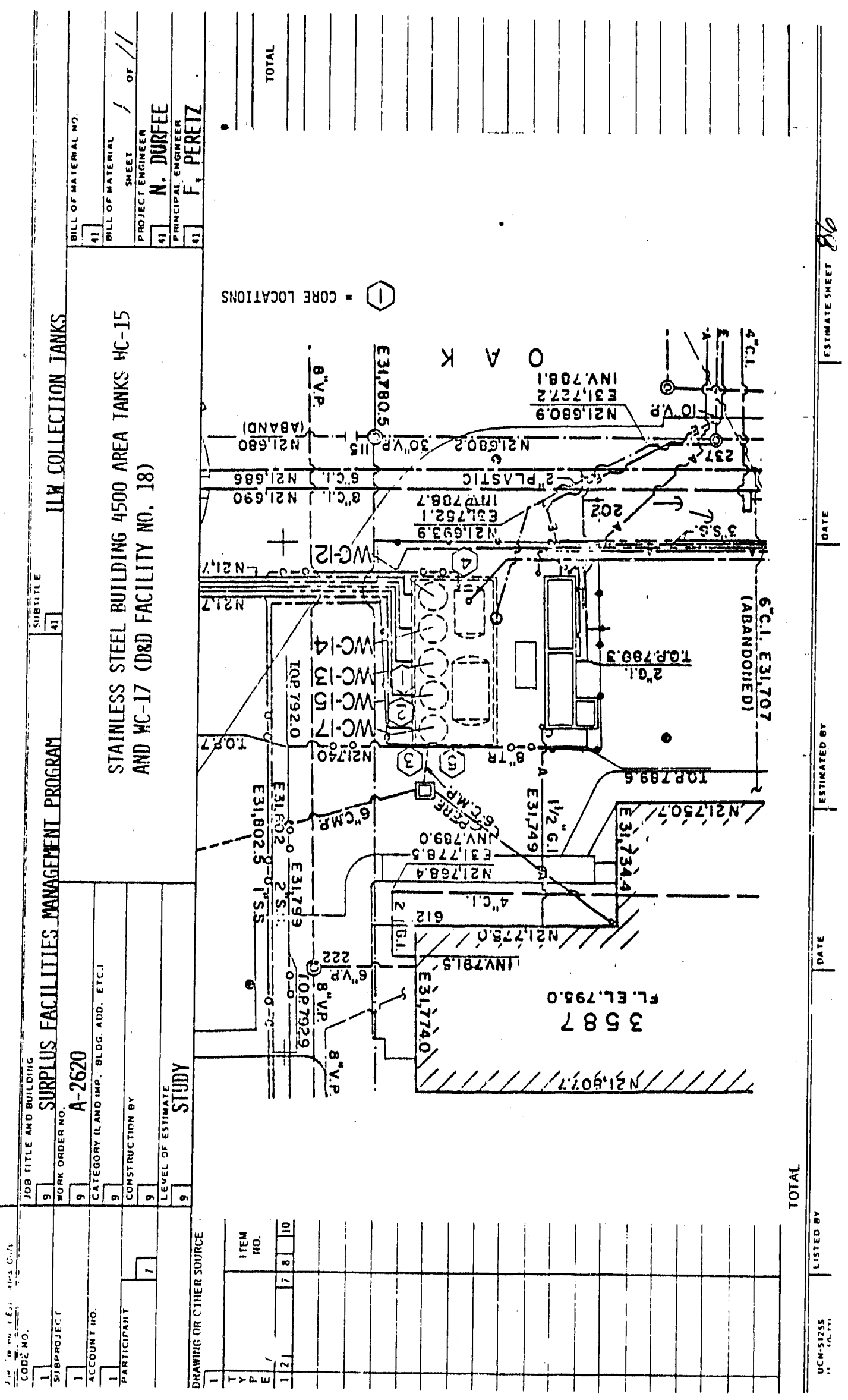




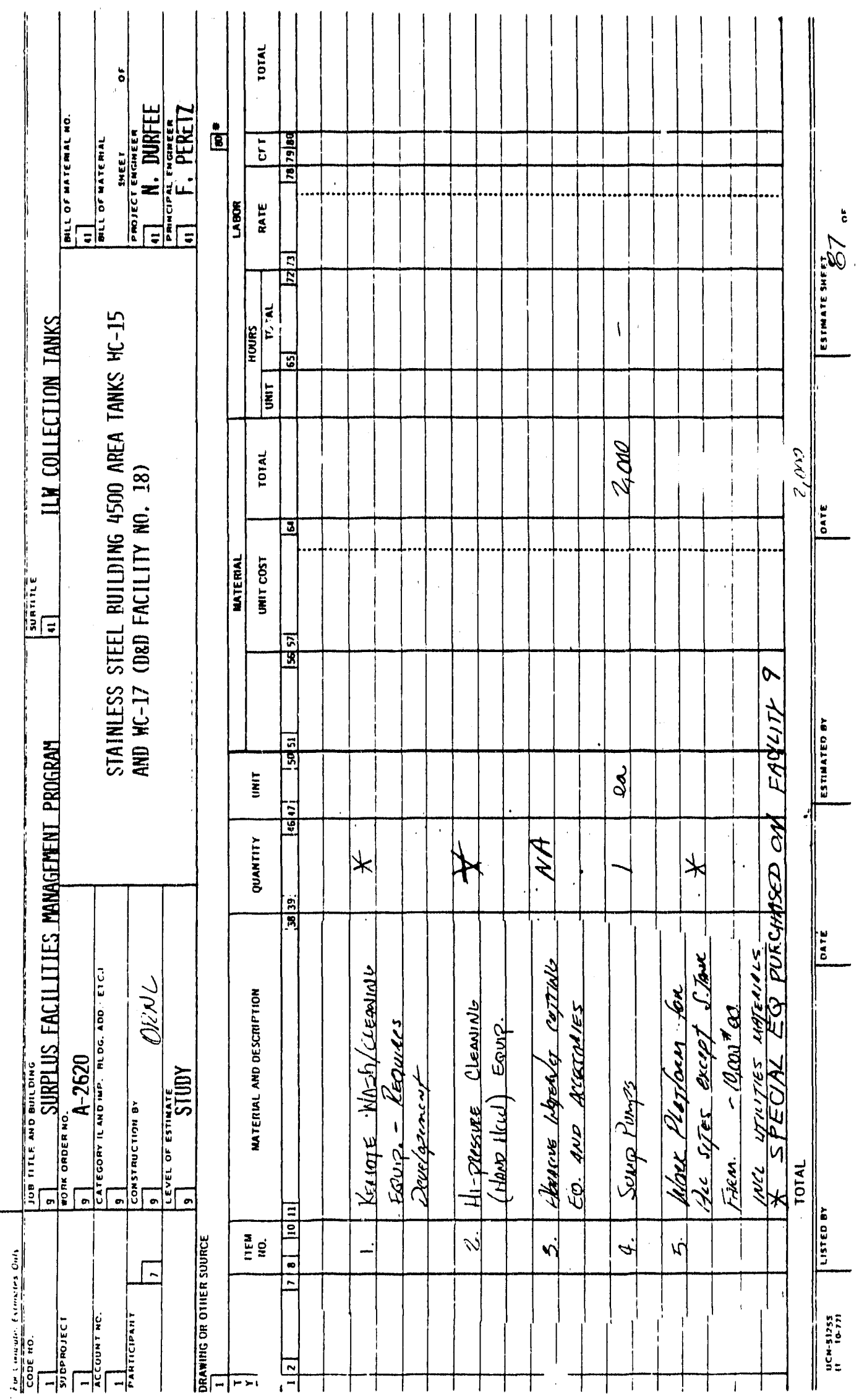




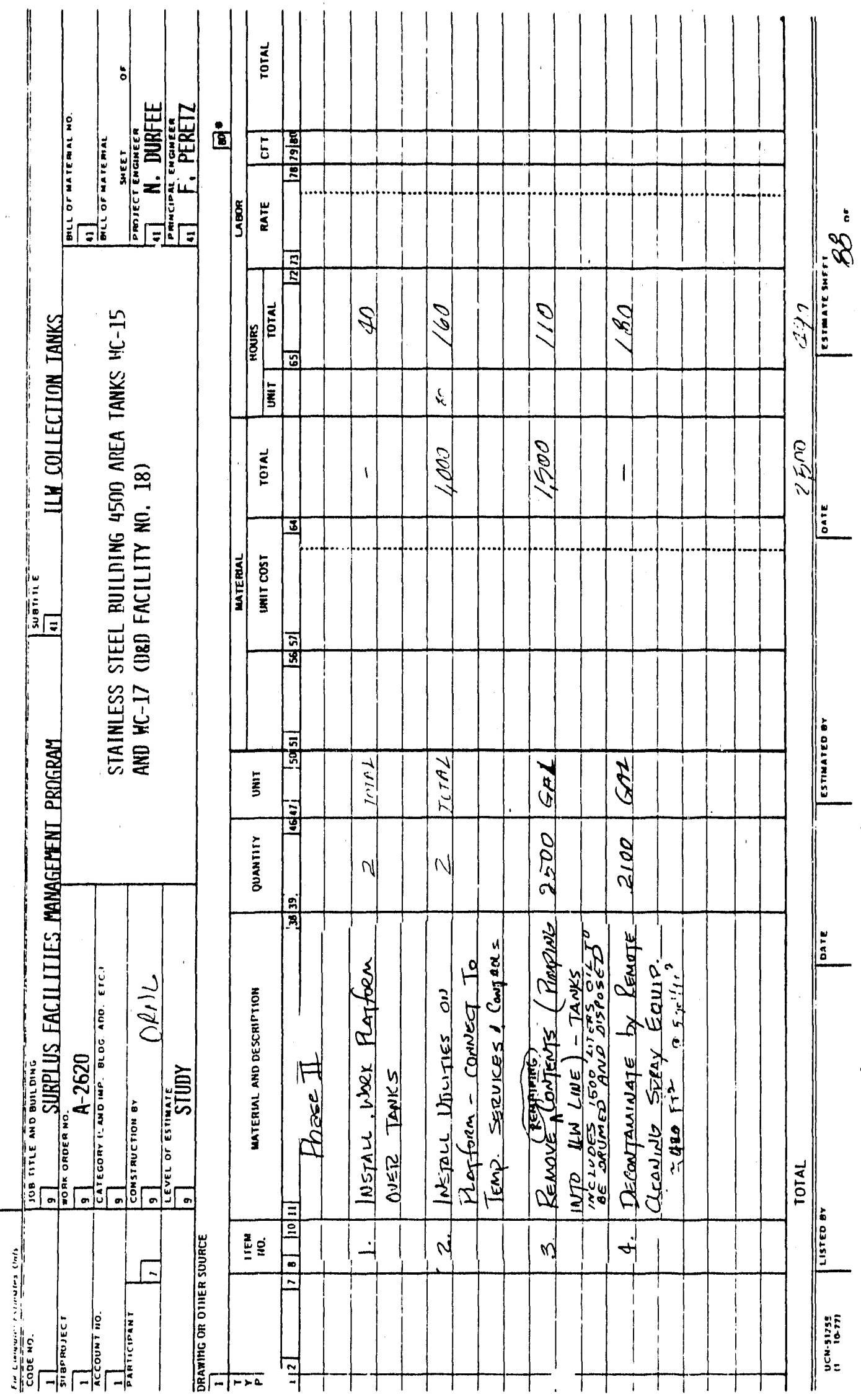




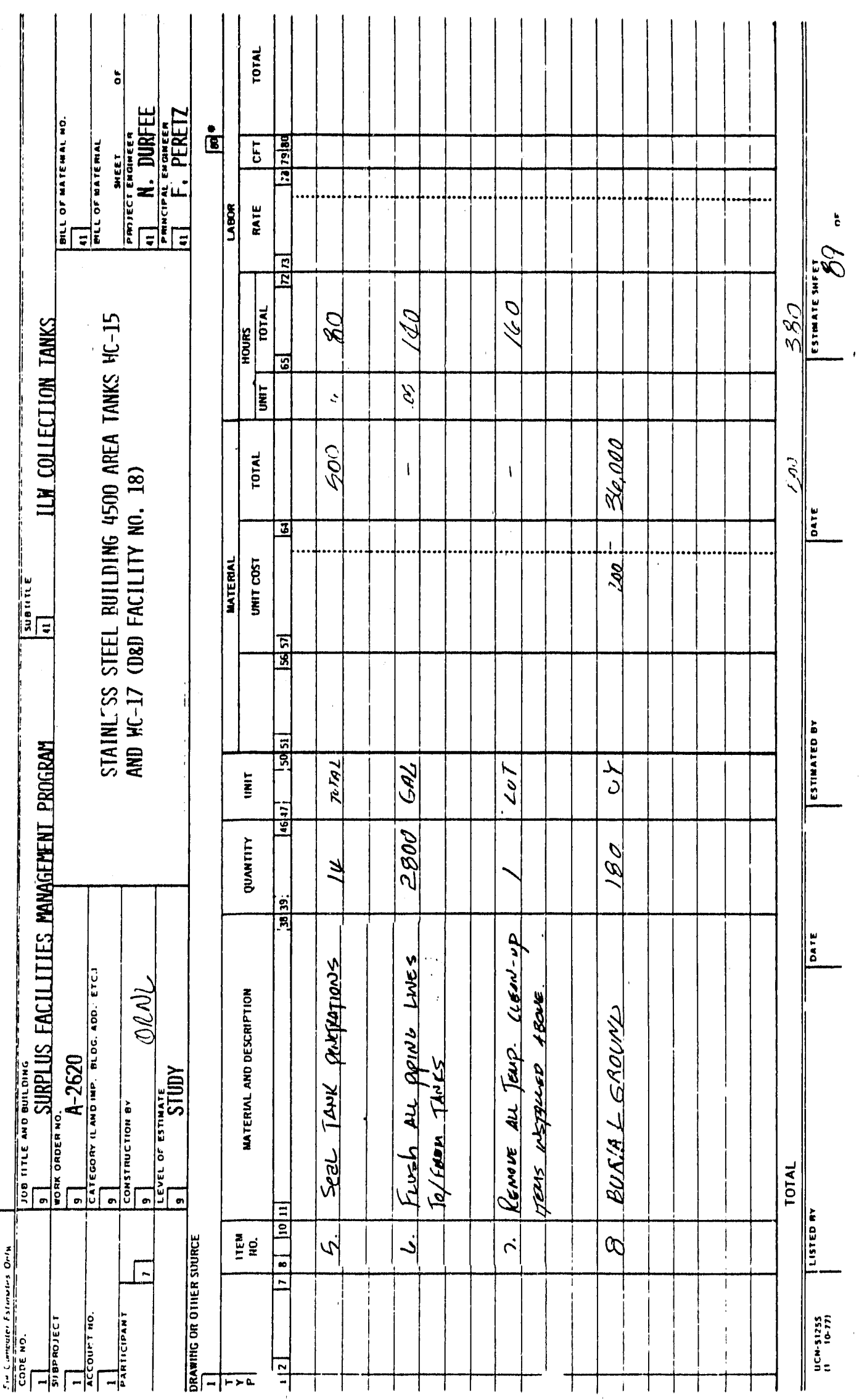




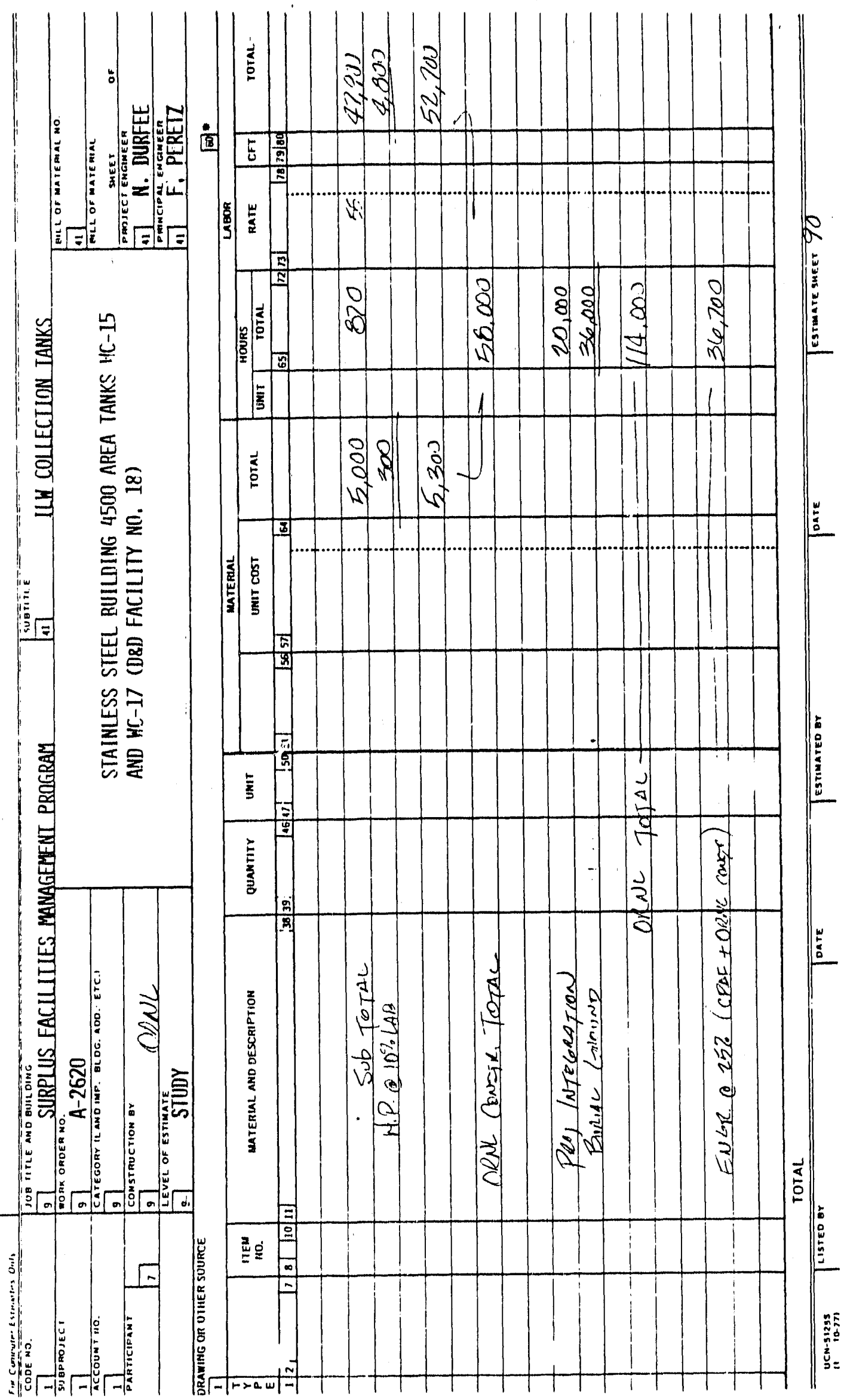




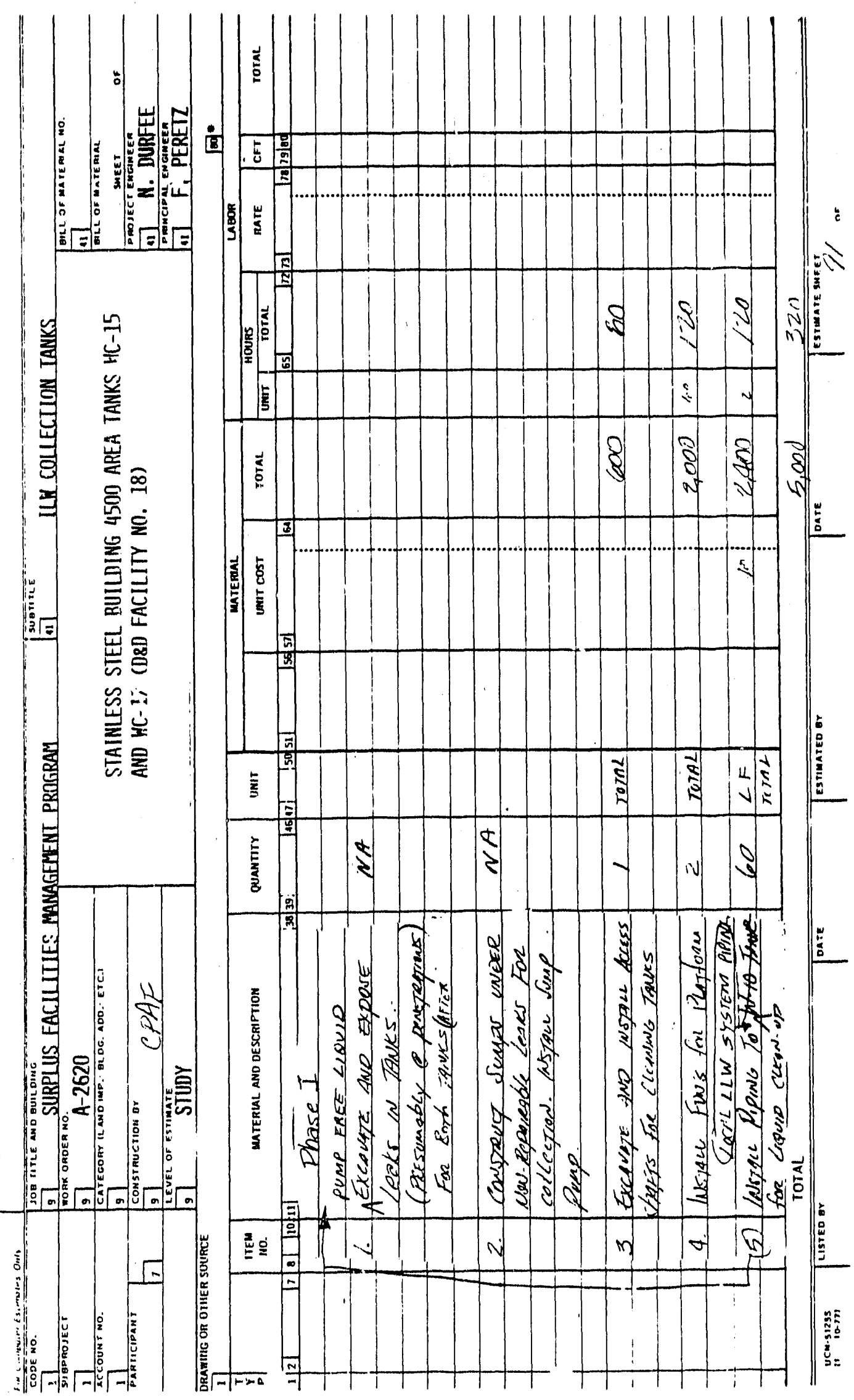




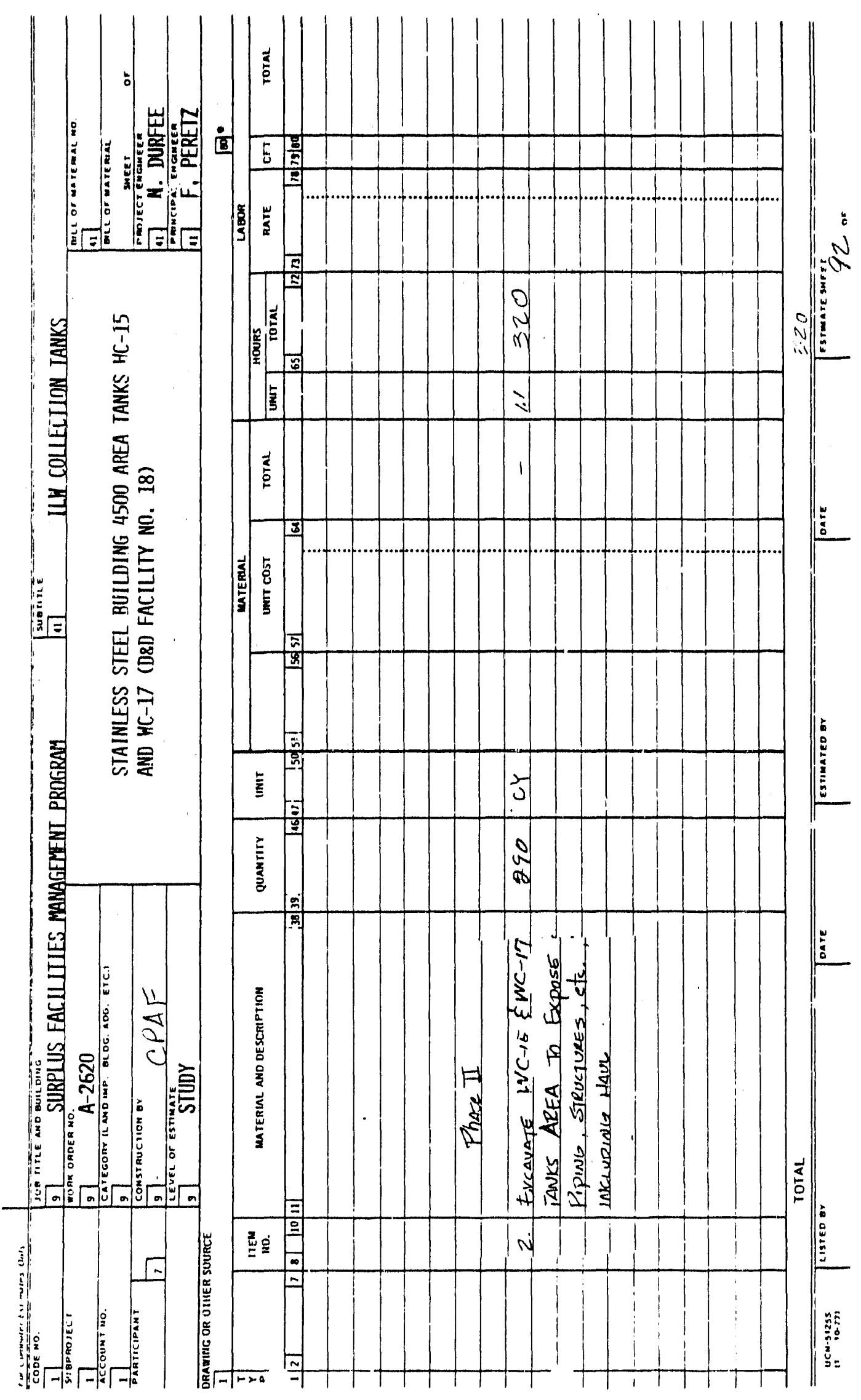




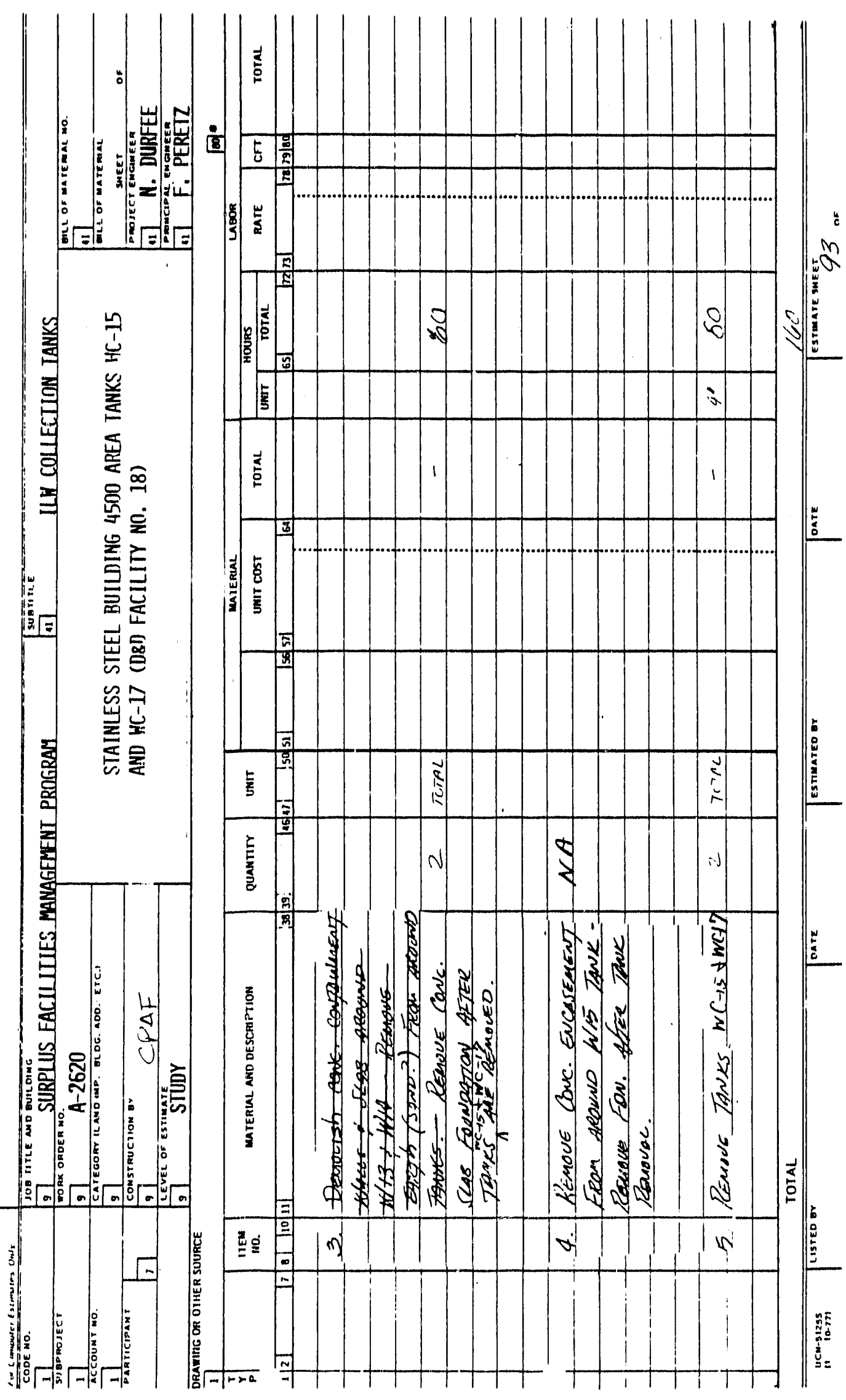




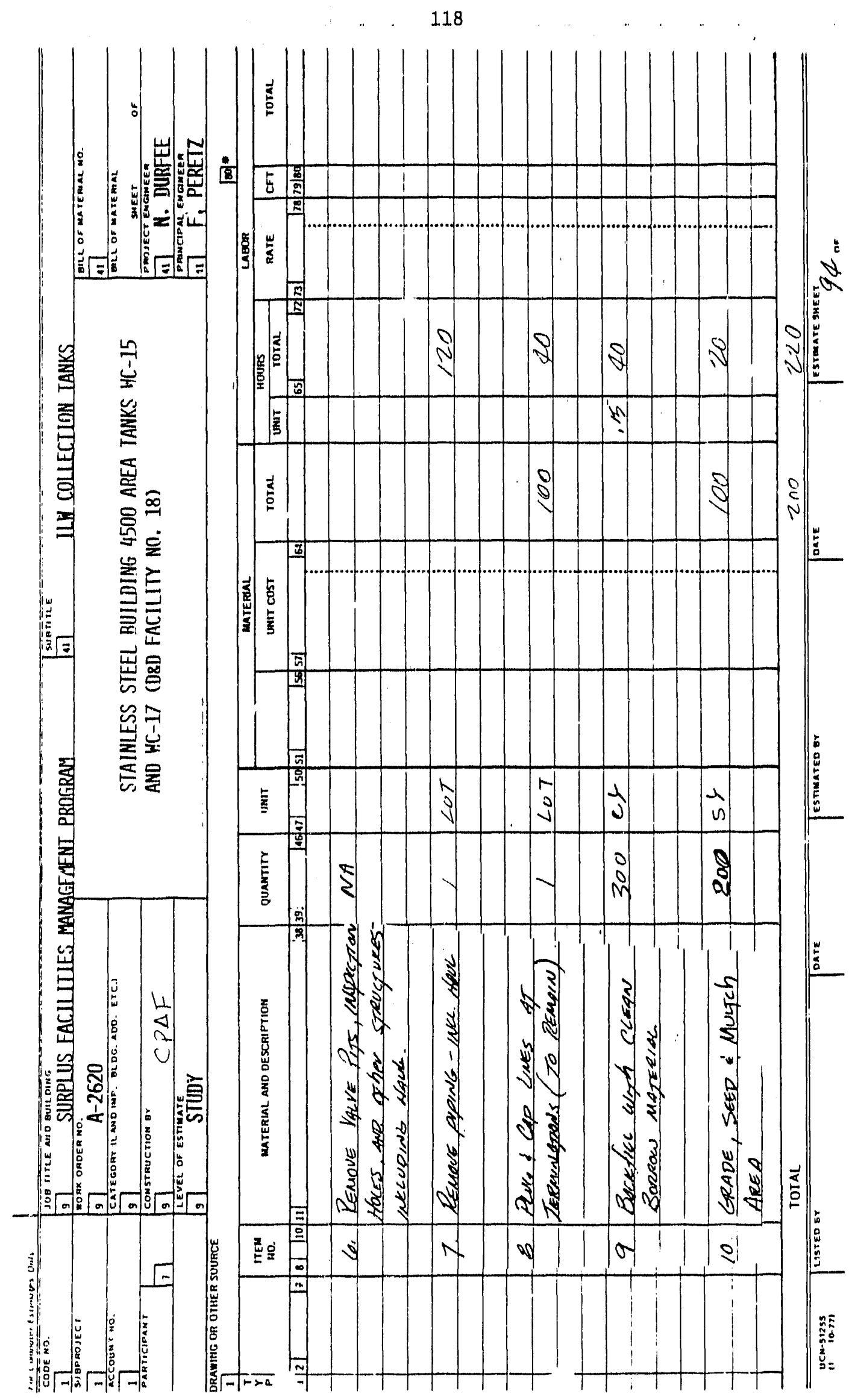




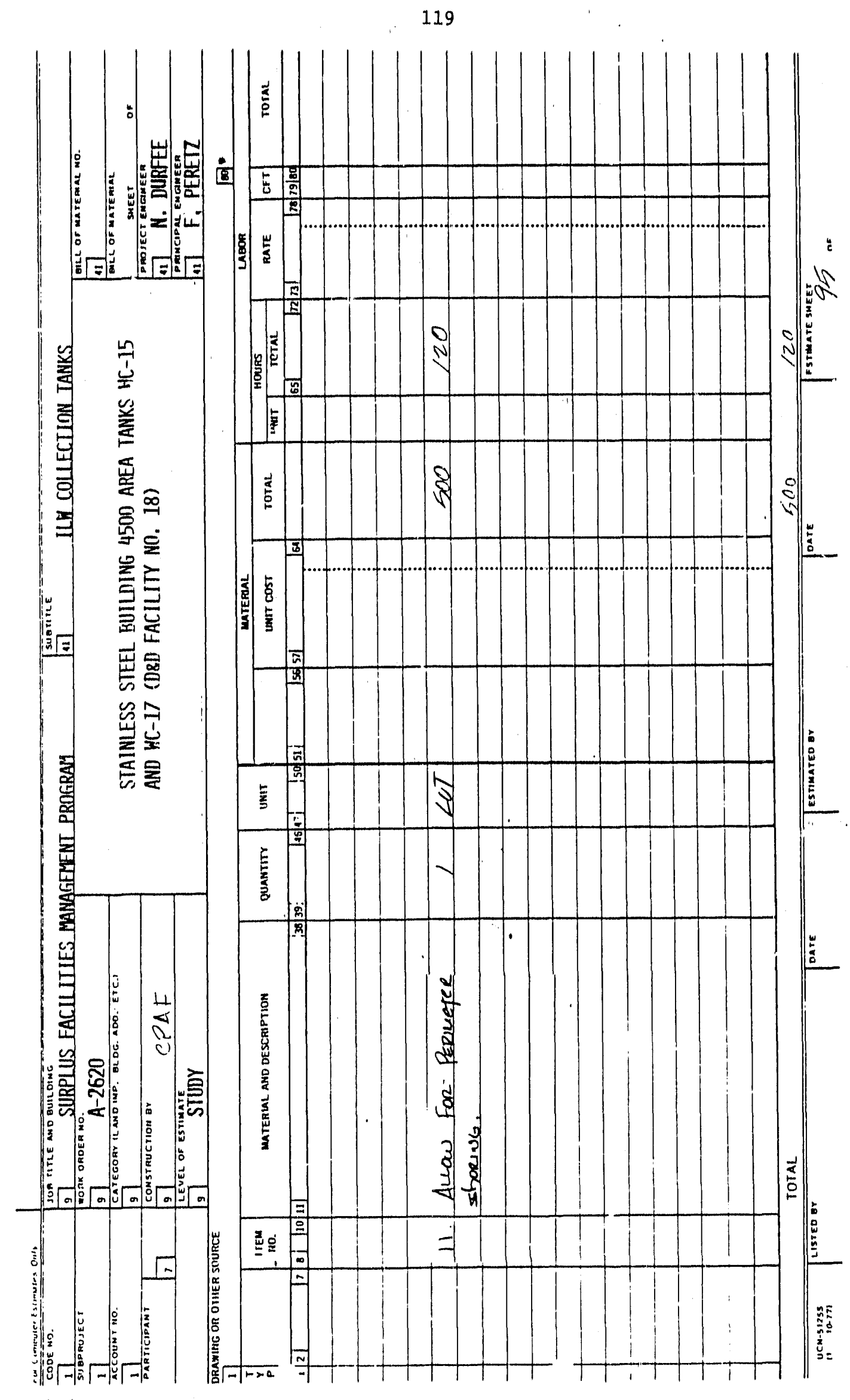




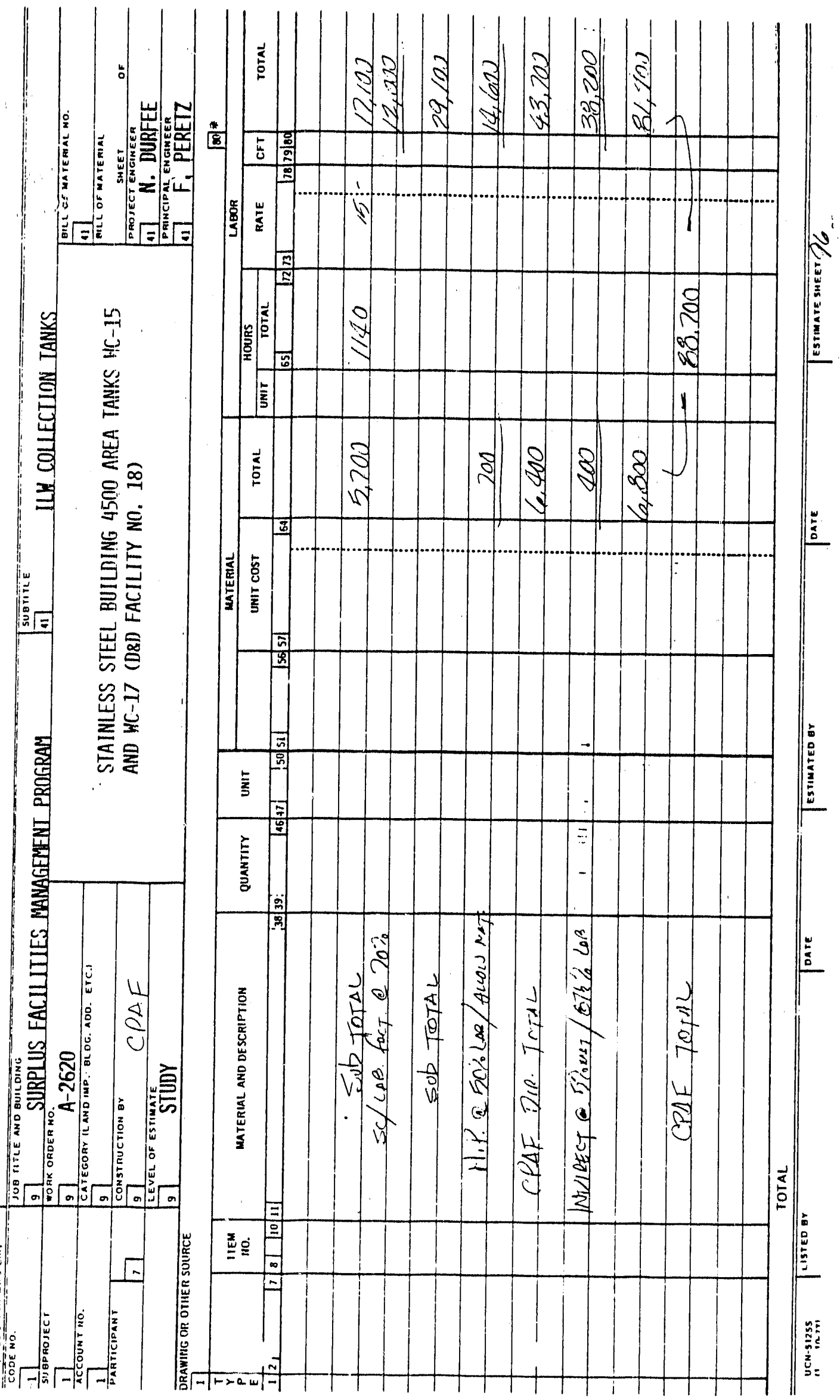


121

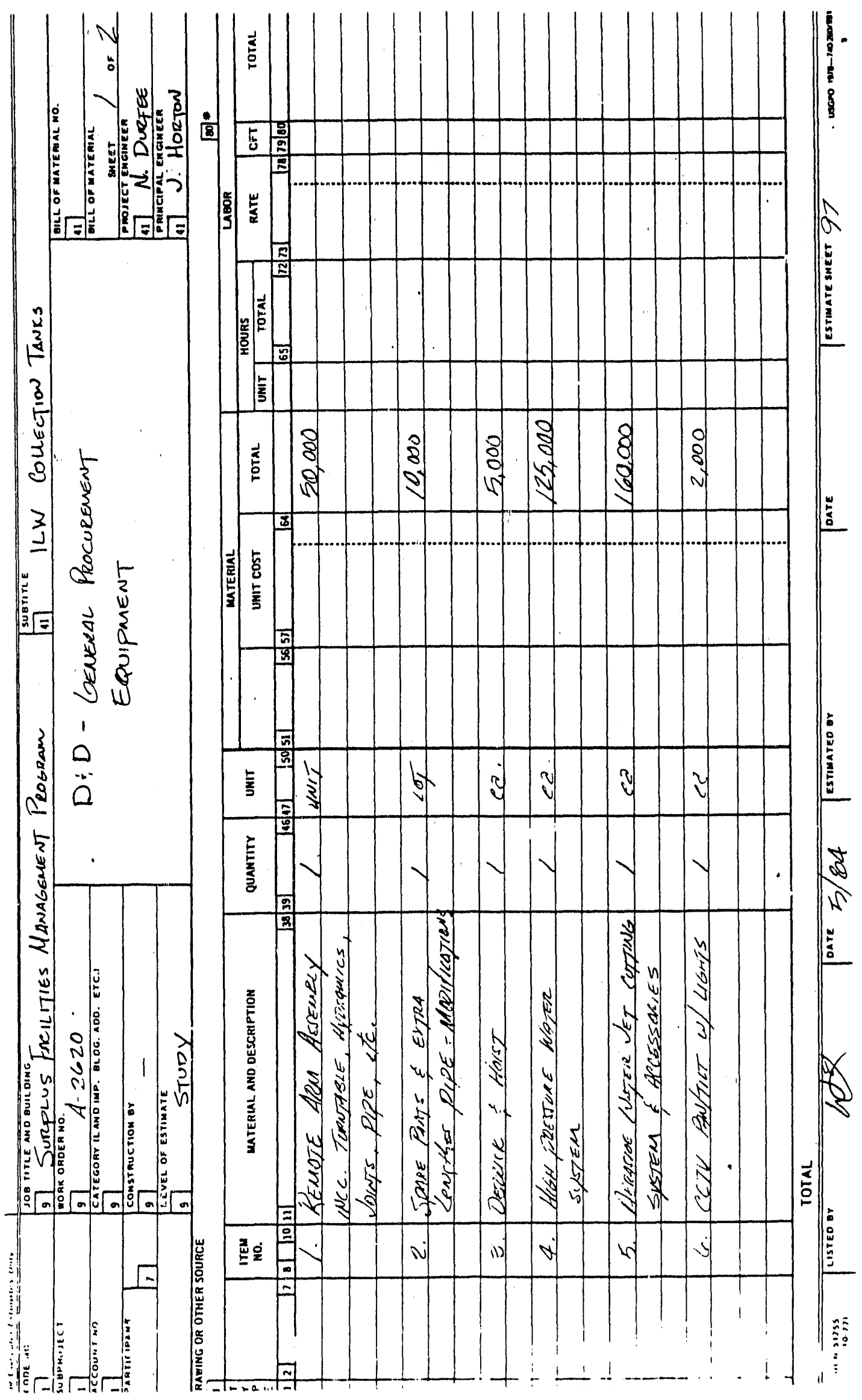




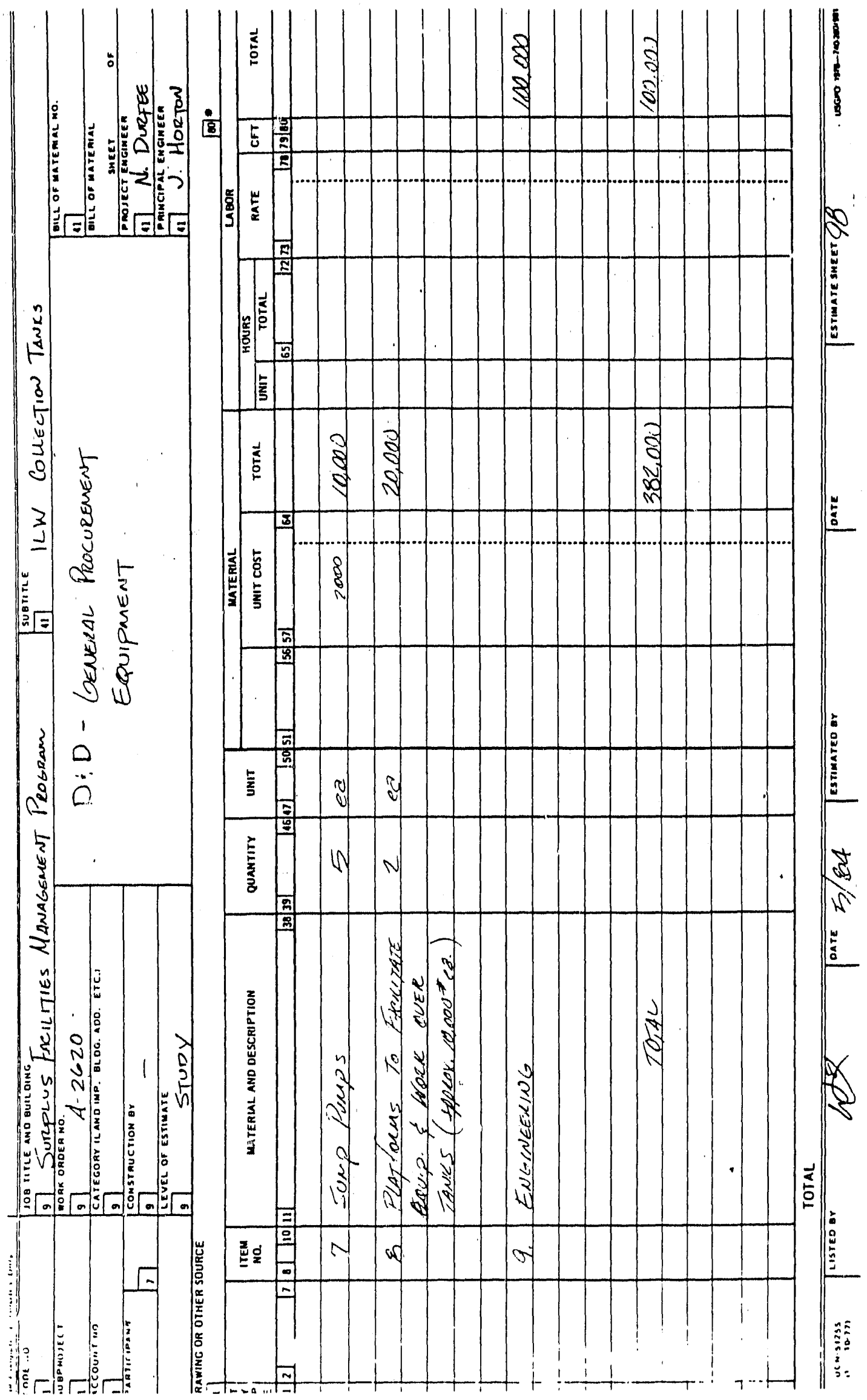



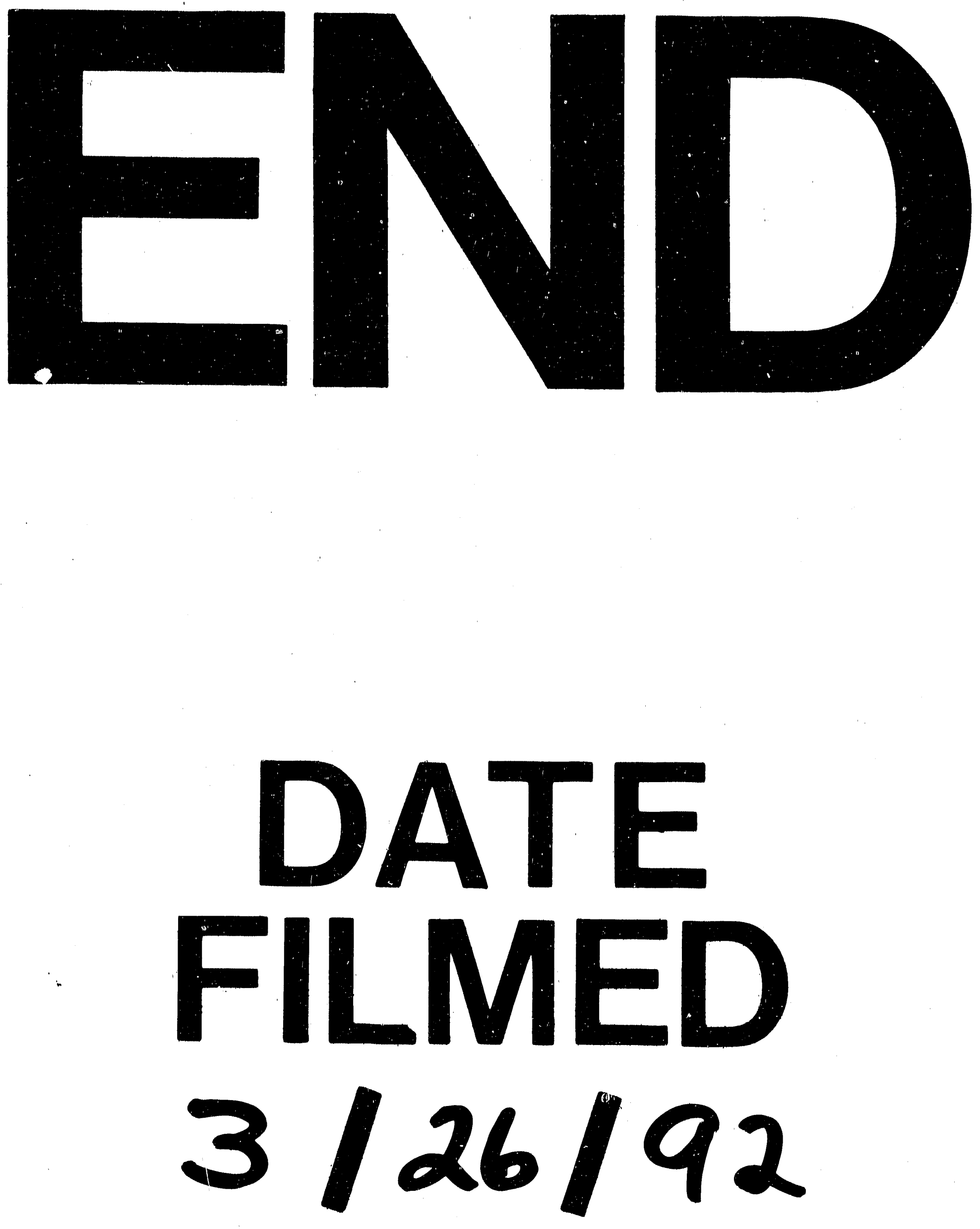
